Dr. Muryanti, M.A.

Sosiologi Hukum dan Kriminal 


\section{SOSIOLOGI HUKUM DAN KRIMINAL}

Penulis: Dr. Muryanti, M.A

Penata Sampul: Manggar Media

Penata Isi: Lisa Aditia Putra

\section{Manggar Media}

Munggur RT 06, No. 16, Srimartani Piyungan Bantul, Yogyakarta 55792

WA: +6285694837418

E-mail: mediamanggar@gmail.com

Website: www.manggarmedia.com

\section{Laboratorium Prodi Sosiologi,}

Fakultas IImu Sosial dan Humaniora,

UIN Sunan Kalijaga

Jl. Marsda Adisucipto, Papringan, Caturtunggal,

Kec. Depok, Kabupaten Sleman, Daerah Istimewa

Yogyakarta 55281

Yogyakarta: Manggar Media, 2020

$\mathrm{hlm}, 14,8 \times 21 \mathrm{~cm}$

ISBN:

Cetakan Pertama: Desember 2020 


\section{Pengantar Penulis}

Sebagai seorang sosiolog membaca fenomena sosial merupakan

$\mathcal{S}_{\text {suatu keniscayaan yang tidak bisa terbantahkan. Fakta sosial }}$ tersebut hadir sebagai suatu peristiwa yang menyebabkan sutau peristiwa yang lain atau pun suatu dampak dari sebuah peristiwa sehingga timbul sebuah peristiwa. Apapun dan bagaimanapun pertistiwa itu hadir tidaklah menjadi soal, yang terpenting adalah bagaimana kita menguraikan sebuah peristiwa tersebut dengan analisis, sehingga menjadi sebuah tesa baru yang memperbarui sintesa yang ada sebelumnya.

Hukum tidak lahir dari ruang hampa. Hukum adalah hasil pergulatan kepentingan (sosial, budaya, ekonomi dan politik) dan mencerminkan standar nilai dan idelogi yang dianut oleh masyarakat dan kekuasaan dalam proses pembuatannya (Rotua valentian, JP vol 49, 2006). Hukum bukan hanya seperangkat peraturan yang harus ditaati oleh masyarakat semata yang terkadang tidak mengetahui bahwa dirinya hidup di Negara hukum yang mempunyai seperangkat peraturan dengan segala bentuknya. Hukum adalah realitas dan kenyataan sosial yang hidup dalam masyarakat. Setiap masyarakat melahirkan hukum dan tentunya hukum itu sendiri lahir untuk kepentingan dan kemaslahatan umat manusia.

Buku bahan ajar ini hanya sebagian kecil dari tulisan yang akan menjadi bahan untuk kita diskusikan pada perkuliahan sosiologi hukum dan kriminal di Prodi Sosiologi, Fakultas Ilmu Sosial dan 


\section{PENGANTAR}

Humaniora, UIN Sunan Kalijaga. Tentu banyak sekali kekurangan dalam tulisan ini, dan saya menerima masukan dari mahasiswa sosiologi untuk bisa mengembangkan tulisan ini sehingga bisa menjadi bahan kuliah yang bisa memberikan pengetahuan bagi setiap orang yang membacanya.

Akhirnya mari kita diskusi tentang sosiologi hukum dan kita bangun perspektif hukum yang baru sehingga kita bangga sebagai warga negara yang tinggal di negara yang berdasarkan hukum dan bukan kekuasaan belaka. Harapan kita, sosiologi hukum tidak menjadi mata kuliah yang utopis tetapi benar-benar bisa memberi warna bagi praktek berhukum kita. Yang artinya ada living law, hukum bisa menjadi rekayasa sosial di masyarakat tanpa memandang kelas sosial. Sehingga tidak ada paksaan dalam berhukum, akan tetapi menjadi kebutuhan bersama dan hukum bukan dibuat oleh kekuasaan, mereka yang melanggarnya dan rakyat "dipaksa" untuk menaati legalitas itu sendiri.

Yogyakarta, Mei 2020

Dosen Pengampu

Mata Kuliah Sosiologi Hukum

\section{Dr. Muryanti, MA}




\section{Pengantar Dekan Fakultas IImu Sosial dan Humaniora}

Assalamu'alaikum Wr.Wb.

Segala puji Allah SWT atas segala karunia-Nya sehingga kita semua selalu dalam keadaan sehat, selalu diberi kemudahan dan kesempatan dalam berkarya. Tidak lupa, salawat dan salam mari kita ucapkan untuk Nabi Muhammad SAW sebagai manusia yang berpengaruh besar pada peradaban manusia sehingga menjadi seperti sekarang ini.

Pertama, saya mengucapkan selamat atas diterbitkannya satu lagi karya tulis dengan judul "Sosiologi Hukum dan Kriminal" yang ditulis oleh Dr. Muryanti, M.A. Secara pribadi saya sangat mengapresiasi semangat dari Dr. Muryanti, M.A. selaku dosen Sosiologi yang saat ini juga menjabat sebagai Ketua Prodi Sosiologi. Meskipun di tengah-tengah wabah pandemi COVID-19, dengan segala penyesuaian bentuk pendidikan, Dr. Muryanti, M.A. tetap mengeluarkan karya-karya ilmiah yang tentunya akan mendukung perkembangan keilmuan bidang sosial di Indonesia.

Saya telah membaca isi buku ini. Buku ini sangat menarik untuk dikaji lebih dalam, terutama dalam memahami kontekstualitas hukum di Indonesia. Buku ini bisa menjadi bahan acuan belajar untuk memahami hukum di Indonesia. Apalagi, Indonesia merupakan 


\section{PENGANTAR}

negara yang memiliki banyak keanekaragaman sosial budaya. Aliranaliran hukum, tokoh-tokoh hukum progresif, hingga pemahaman mengenai sosiologi hukum juga dibahas dalam buku ini.

Kelahiran buku ini juga merupakan sumbangsih pemikiran terhadap hukum. Bahwa hukum tidak bisa dimaknai secara sempit. Proses terbentuknya undang-undang juga menjadi bagian kajian penting apakah hukum mewakili aspirasi dan kepentingan masyarakat. Tidak berhenti dalam proses pembentukannya saja, penerapan hukum hingga bagaimana seseorang atau kelompok melakukan tindakan yang disebut melanggar hukum juga perlu dikaji dari berbagai persepektif. Dari sini, kajian ilmu sosial sangat penting untuk dipelajari.

Saya berharap, semoga buku ini bisa membantu para mahasiswa dan mahasiswi dalam mempelajari konsep-konsep Sosiologi Hukum dan Kriminal. Saya juga berharap hadirnya karya ilmiah ini, mampu menginspirasi dosen-dosen di Fakultas Ilmu Sosial dan Humaniora UIN Sunan Kaljaga Yogyakarta untuk terus berkarya. Sekali lagi, saya ucapkan selamat kepada Dr. Muryanti, M.A. atas terbitnya karya ini.

Terimakasih

Wassalamu’alaikum, Wr.Wb.

Dr. Mochamad Sodik, S.Sos., M.Si.

Dekan Fakultas Ilmu Sosial dan Humaniora UIN Sunan Kaljaga Yogyakarta 


\section{Daftar Isi}

Pengantar Penulis iii

Pengantar Dekan v

Daftar Isi vii

Daftar Bagan dan Tabel ix

Bab I:

Aliran Hukum dan Bekerjanya Hukum 1

Aliran dalam Hukum 2

Bekerjanya Hukum 11

Bab II:

Memahami Sosiologi Hukum 19

Pengertian Sosiologi Hukum 20

Model Kajian Sosiologi Hukum 26

Obyek Kajian Sosiologi Hukum 27

Letak dan Ruang Lingkup Sosiologi Hukum 28

Teori-Teori dalam Sosiologi Hukum 28

Latar Belakang Lahirnya Sosiologi Hukum $\quad 30$

Bab III:

Pemikiran Sosiologi tentang Sosiologi Hukum 35

Emile Durkheim 36

Max Weber $\quad 41$

Talcot Parson 46 


\section{Bab IV:}

\section{Hukum Progresif}

Negaara Hukum $\quad 51$

Pengadilan Progresif (Kasasi) 55

Pejabat Hukum Progresif $\quad 56$

Hukum Progresif 61

Bab V:

Penegakan Hukum (Law Enforcement) 65

Pengertian Penegakan Hukum 66

Alur Penegakan Hukum 68

Penegakan Hukum dan Struktur Masyarakat 69

Penegakan Hukum di Indonesia $\quad 71$

\section{Bab VI:}

Sosiologi Hukum Islam

Pengertian Syariah dan Fiqh $\quad 74$

Pengertian Hukum Islam 75

Hukum Islam Pada Zaman Belanda $\quad 77$

Hukum Islam dan Hukum Adat $\quad 78$

Materi Hukum Islam secara Nasional $\quad 79$

Sosiologi Hukum Islam $\quad 81$

\section{Bab VII:}

Definisi dan Ruang Lingkup Kriminologi 83

Pengertian Kriminologi $\quad 84$

Perkembangan Kriminologi 88

\section{Bab VIII:}

Teori-Teori tentang Kejahatan 95

Penyebab Kejahatan 96

Kejahatan dalam Perspektif Psikologis $\quad 101$

Kejahatan dalam Perspektif Sosiologis 105 
Bab IX:

Viktimologi dan Pemenjaraan

Pemenjaraan

Bab X:

Kasus-Kasus dalam Perspektif Hukum dan Kriminal

125

Kekerasan Dalam Rumah Tangga (KDRT)

Pelibatan Anak Pada Aktivitas Politik

Analisis Hukum Agraria 


\section{Daftar Bagan dan Tabel}

Tabel 1 Pranata yang digunakan dalam Masyarakat untuk 13 Menyelesaikan Masalah

Bagan 1 Hubungan antara Ilmu Hukum dan Sosiologi 22 Tabel 2 Kaidah Hukum yang Berlaku di Masyarakat 22 Bagan 2 Tujuan Hukum 68

Bagan 3 Alur Penegakan Hukum 69

Tabel 3 Penyelesaian Masalah dalam Masyarakat $\quad 70$

Tabel 4 Sejarah Perkembangan Akal Pemikiran Manusia 93

Tabel 5 Zona Wilayah Perkotaan dan Tindakan Kriminal 112

Tabel 6 Data Kasus KDRT 130 
BAB I

Aliran Hukum dan Bekerjanya Hukum 
Sebagai sebuah ilmu yang bersifat praksis, sosiologi hukum

$\mathcal{O}$ menganalisis hukum secara luas. Hukum itu memang tidak bisa dimaknai secara sempit dalam bentuk undang-undang semata, akan tetapi proses kelahiran sebuah undang-undang dan dampak berlakunya sebuah undang-udang (peraturan) dalam masyarakat pun perlu dikaji. Sehingga masyarakat merasakan manfaat dari keberadaan sebuah peraturan. Atau hukum menghadirkan kebahagiaan dalam masyarakat. Untuk mengawali pembahasan dalam mata kuliah ini kita akan mengenali hukum itu lebih dekat, sehingga kita tidak menyimpulkan bahwa hukum itu sama dengan produk perundangundangan.

\section{Aliran dalam Hukum}

Aliran pemikiran hukum tidak bisa dilepaskan dari lingkungan zamannya, ia sering dilihat sebagai suatu jawaban atas permasalahan hukum atau menggugat suatu pemikiran yang dominan pada suatu waktu. Aliran-aliran pemikiran dalam ilmu hukum itu secara konvensional (Barat) dibedakan atas;

\section{Hukum Alam}

Hukum alam tumbuh di Yunani dan Romawi yang di kedua negara tersebut memiliki perbedaan dalam penerapannya. Karena memang hukum alam ini tidak tunggal. Pemikiran Yunani tentang Hukum lebih bersifat teoritis dan filosofis, sedangkan Romawi lebih praktis dan mengaitkan hukum alam dengan hukum positif. 
Tiga tokoh yang tidak bisa dipisahkan dari Yunani adalah Plato dan Aristoteles yang menyatakan bahwa berhukum itu untuk menciptakan keadilan, baik keadilan korektif atau distributif. Tokoh dari Romawi adalah Cicero yang menyatakan konsepnya true law (hukum yang benar) harus berdasarkan pada penalaran yang benar (right reason).

Hukum alam sebagai metode selalu berusaha untuk menciptakan aturan-aturan yang mampu menghadapi keadaan yang berbeda-beda. Ia tidak mengandung kaidah, tetapi hanya mengajarkan bagaimana membuat aturan yang baik. Hukum alam secara substansi merupakan hukum alam yang membuat kaidah-kaidah. Ia menciptakan sejumlah besar aturan-aturan yang dilahirkan dari beberapa asas yang absolut sifatnya yang dikenal dengan Hak Azasi Manusia (Teguh, 2009).

\section{Positivisme}

Aliran positivisme berakar dari filsafat Yunani yakni Epicurus. Sementara itu positivsme dari aliran hukum mendapat banyak pengaruh dari positivisme sosiologis yang dimotori oleh Auguste Comte dan Herbert Spencer. Kaum positivis menganut paham monisme dalam ihwal metodologi keilmuan. Dalam kajian sains hanya ada satu saja metode untuk menghasilkan kesimpulan yang lugas, yakni metode scienties. Mempelajari benda-benda mati dalam ilmu Fisika sama halnya dengan mempelajari manusia yang memiliki jiwa dan ruh. Perilaku pada ranah yang berbeda itu sama-sama dikontrol oleh hukum sebab akibat yang berlaku universal. Menurut Rousseau, positivisme sepertinya hendak menyatakan bahwa manusia-manusia itu memang dilahirkan sebagai makhluk bebas, akan tetapi di dalam kehidupan yang nyata di masyarakat mereka akan menemukan dirinya terikat dimana-mana. Kehidupan manusia dikontrol dan dikuasai oleh seperangkat hukum positif yang lengkap dan tuntas serta bersanksi, sedemikian rupa sehingga diyakini bahwa law is society. Hukum 
dipositifkan dengan statusnya yang tertinggi diantara berbagai norma (the supreme state of law), yang teridri dari pernyataan tentang berbagai perbuatan yang didefinisikan sebagai "fakta hukum" dengan konsekuensinya yang disebut "akibat hukum".

Perkembangan hukum yang diperlukan untuk mengontrol kehidupan negara bangsa yang modern ini mencita-citakan terwujudnya jaminan akan kepastian dalam pelaksanaan hukum sebagai sarana penata tertib itu. Hukum menurut modelnya yang baru ini diperlukan para reformis untuk mengatasi kesemenamenaan para penguasa otokrat yang mengklaim dirinya sebagai secara sepihak sebagai penegak hukum yang bersumber dari kekuasaan Ilahi yang maha Sempurna.

Dari sinilah berawal pemikiran yang mengetengahkan dan memperjuangkan ide bahwa apa yang dimaklumatkan sebagai hukum harus mempunyai statusnya yang positif dalam arti telah disahkan tegas-tegas (positif) sebagai hukum dengan membentuknya dalam wujud produk perundang-undangan. Inilah pemikiran positivisme yang berkembang pasca revolusi Perancis yang serta merta menolak segala pemikiran yang serba metafisik dan menolak praktik-praktik penyelenggaraan tertib kehidupan atas dasar rujukan yang metayuridis. Inilah tipe hukum yang dikenal dengan istilah hukum undang-undang. Setiap unsur-unsur yang ada di dalamnya ditandai dengan penomoran. Setiap unsur ini terbaca sebagai aturan berupa kalimat yang menyatakan ada tidaknya sutau peristiwa atau perbuatan tertentu (disebut dengan fakta hukum), yang disusul dengan pernyataan tentang apa yang akan menjadi akibatnya (akibat hukum). Sehingga dalam khazanah peristilahan hukum nasional modern, setiap baris aturan dalam setiap undang-undang disebut normanorma positif dan keseluruhannya disebut dengan hukum positif. Jaminan akan berlakunya kepastian hukum, demi terwujudnya keteraturan dalam kehidupan nasional yang diupayakan lewat langkah-langkah positivisasi dan sistematisasi. 
Hukum nasional yang menganut ajaran positivisme yang marak di Barat dan mengalami puncak keberhasilannya pada akhir abad 18 ini kemudian dikenali sebagai hukum positif dan tampil dalam rupa hukum perundang-undangan. Berawal dari sini lahirnya hukum nasional yang dituliskan atas dasar konsepkonsep kaum positivis yang akan dirawat oleh sebarisan hukum yang profesional. Dari sini awal mula hukum sebagai normanorma penata tertib yang tidak menjadi bahasan para filosof dan atau kaum moralis, melainkan kian berlanjut ke para ahli hukum penggunanya (ahli hukum, the lawyers) dan atau pengkajinya yang ilmuwan (sarjana hukum, jurist). Dari sini lahirlah kajian ilmu baru yang disebut dengan ilmu hukum tentang kehidupan dan perilaku warga masyarakat yang mengikuti norma-norma.

Kritik terhadap paham legisme diberikan oleh kelompok Critical Legal Study (CLS) yang sejak tahun 1970-an mengkritik pikiran berikut rasional dan rasionalitas kaum yuris legal yang liberal itu. Adalah paradigma mereka yang tergabung dalam CLS yang mehatakan bahwa masyarakat bukanlah struktur yang terbangun sepenuhnya dari konsensus-konsensus dan yang karena itu lalu mampu bertahan secara penuh dan berterus pada konsensus-konsensus itu. Kritik yang dilakukan oelh kaum CLS pada tahun 1970an tersebut sebenarnya sudah dilakukan pada tahun 1940-an oleh kaum Realis (Soetandyo).

\section{Utilitarianisme}

Aliran ini bahwa tujuan hukum dan keadilan adalah untuk mewujudkan kebahagiaan yang sebesar-besarnya untuk sebanyakbanyaknya orang dan tujuan peruandang-undangan adalah untuk kebahagiaan semua orang (masyarakat); John Stuart Mill yang menyatakan bahwa berhukum adalah suatu tindakan untuk pencapaian kebahagiaan dan sangat keliru jika hukum tidak bertujuan untuk mendapatkannya; Rudolf Von Jhering yang menyatakan bahwa hukum bertujuan untuk membentuk 
masyarakat yang baik.

\section{Hukum Murni}

Tokohnya adalah Hans Kelsen, tetapi banyak juga yang menggolongkan pada golongan positivisme karena pandangannya tentang isi kaidah-kaidah hukum yang merupakan produk dari negara. Secara ringkas Hans Kelsen ingin membersihkan ilmu hukum dari anasir-anasir non hukum, seperti; sejarah, moral, sosiologis, politik dan sebagianya. Kelsen menolak masalah keadilan dijadikan pembahasan dalam ilmu hukum. Menurutnya keadilan adalah masalah ideologi yang ideal rasional (Hans, 2006).

\section{Historisme}

Tokohnya adalaah Friedrich Carl von Savigny dengan inti ajaran historisme adalah bahwa hukum merupakan pencerminan dari jiwa rakyat, hukum itu tumbuh bersama-sama dengan kekuatan inti rakyat dan akhirnya mati jika bangsa itu kehilangan kebangsaannya. Hukum itu bukan dibuat akan tetapi ditemukan dalam masyarakat, hukum yang benar-benar hidup adalah hukum kebiasaan. Ciri khas mereka adalah ketidakpercayaan pada pembuatan undang-undang dan kodifikasi. Peranan pakar hukum lebih penting daripada pembuatan undang-undang.

\section{Sosiologis}

Hukum adalah kenyataan sosial dan bukan hukum sebagai kaidah. Hubungan antara positivisme dan sosiologis adalah keduanya memusatkan perhatiannya pada hukum tertulis atau perundang-undangan. Kalau positivisme memandang kaidahkaidah dalam bentuk undang-undang, sedangkan sosiologis memandang hukum adalah kenyataan sosial. Ia mempelajari bagaimana dan mengapa tingkah laku sosial yang berhubungan hukum dan pranata hukum sebagaimana yang berlaku di suatu negara. Positivisme memandang hukum sebagai sesuatu yang otonom dan mandiri sedangkan sosiologi hukum memandang hukum dipengaruhi oleh faktor-faktor non hukum yang ada di 
dalam masyarakat; ekonomi, politik, budaya, sosial. Positivisme hanya mempersoalkan hukum sebagai das sollen (apa yang seharusnya), sedangkan sosiologi hukum memandang hukum sebagai das sein (dalam kenyataannya). Positivisme berpandangan yuridis dogmatis sedangkan sosiologi hukum berpandangan empiris. Metode yang digunakan oleh positivisme adalah preskriptif yaitu menerima hukum positif dan penerapannya sedangkan sosiologi adalah deskriptif.

\section{Antropologis}

Hukum mencakupi suatu pandangan masyarakat tentang kebutuhannya untuk survival, hukum juga merupakan aturan yang mengatur produksi dan distribusi kekayaan dan metode untuk melindungi masyarakat terhadap kekacauan internal dan musuh dari luar.

\section{Realisme}

Aliran ini tumbuh dari aliran realias dalam pemikiran filsafat umum. James dikenal sebagai pencetus teori pragmatis, suatu filsafat positif yang menolak sistem tertutup dan berlaku absolut dan asli dan beralih pada pandangan tentang fakta-fakta, tindakan, kekuatan (powers). Hal ini dimungkinkan untuk melawan halhal yang bersifat dogmatik, artifisial dan menganggap ada kebenaran mutlak. Para Yuris yang beraliran realis pada umumnya berpendapat bahwa ilmu hukum yang sesungguhnya adalah dibangun dari suatu studi tentang hukum dalam pelaksanaannya (the law in action).

\section{1) Realisme Amerika}

Tokoh-tokohnya adalah; Oliver Wendell Holmes, selama 30 tahun menjabat Hakim Agung dengan kata-katanya yang terkenal the life of the law has been, not logic, but experience. Aspek-aspek empiris dan pragmatis dari hukum merupakan hal yang penting. Hukum adalah kelakuan aktual para hakim (patterns of behaviors) dimana patterns of behaviour (keputusan) 
hakim itu ditentukan oleh 3 faktor; kaidah-kaidah hukum yang dikonkretkan oleh hakim dengan metode interpretasi dan konstruksi, moral hidup pribadi hakim dan kepentingan sosial. Llewellyn menyatakan bahwa hukum harus diterima sebagai sesuatu yang terus menerus berubah. Tujuan hukum harus senantiasa dikaitkan dengan tujuan masyarakat dimana hukum itu berada. Masyarakat merupakan proses yang terus menerus berubah secara berkesinambungan sehingga perubahan hukum merupakan hal yang esensial. Hal yang fundamental bagi aliran realis adalah keyakinan mereka tentang perlunya investigasi yang menggunakan metode objektif. Jerome Frank dengan pengertiannya bahwa hukum adalah bukan Undangundang melainkan seperangkat kenyataan-kenyataan, suatu keputusan pengadilan yang berkaitan dengan kenyataan yang ada. Benjamin Cardoso, seorang hakim yang terkenal di USA, Pokok-pokok pandangannya adalah hukum adalah kegiatan hakim di pengadilan yang terikat pada tujuan hukum, yaitu kepentingan umum; hakim bebas memutus tetapi dengan batasan, tidak boleh bertentangan dengan kepentingan umum.

\section{2) Realisme Skandinavia}

Bersama dengan aliran Amerika merupakan suatu penolakan umum terhadap das sollen dalam studi hukum dan juga menolak spekulasi metafisik dalam penyelidikan kenyataan-kenyataan dari sistem hukum. Realisme ini lebih menitikberatkan perhatiannya pada aspek-aspek perilaku hakim daripada pernyataan-pernyataan tentang hukum yang tumbuh dari perhatian pada sifat hak-hak dan kewajibankewajiban subyek hukum. 
Banyaknya aliran hukum yang berkembang di dunia tersebut, akan tetapi yang menjadi mainstream adalah dua aliran besar, yakni legal positivism dan legal realism. Sementara aliran yang lain itu mengikuti aliran yang mainstraim. Utilitarianisme, historisme, sosiologis-antropoligis mempunyai landasan pikir yang sama dengan Realisme. Sedangkan aliran alam merupakan cikal bakal lahirnya aliran positivisme yang berkembang saat ini.

Positivisme dan Realisme sama-sama melahirkan hukum positif yang berlaku di masyarakat. Dalam positivisme disebut sebagai undang-undang (law), Realisme dikenal dengan act. Proses pembuatan peraturan tersebut juga melibatkan badan legislatif, yang membedakan adalah pada pelaksanaannya. Aliran Positivisme selalu mengacu pada undang-undang untuk mengatur masyarakat atau yang dikenal dengan hukum positif artinya hukum yang diacu saat ini yang mengatur secara tegas suatu kasus tertentu. Kebalikannya dengan realism yang lebih mengutamakan hati nurani masyarakat dalam menerapkan sebuah undang-undang. Sehingga Realisme sangat cepat dalam merespon setiap fakta hukum yang berkembang, sedangkan Positivisme agak lambat merespon sebuah persoalan yang ada di masyarakat. Keterlambatan tersebut dikarenakan mengacu kepada setiap prosedur secara detail dalam menghadapi setiap peristiwa hukum dan untuk menghasilkan peraturan yang baru. Realisme berkembang sebagai kritik terhadap positivisme dalam pelaksanaannya tidak memperhatikan aspek kemanusiaan atau hati nurani (conscience) dalam berhukum. Aliran realisme selalu disebut sebagai pahlawan karena dalam bekerjanya hukum selalu mempunyai itikad baik dan memperhatikan kepentingan masyarakat, terutama pihak yang tertindas dalam berhukum. Sementara itu positivisme dianggap berhukum yang tidak berperasaan dan tidak mempunyai keberpihakan kepada masyarakat yang lemah. Untuk menutupi kekurangan tersebut, maka lahirlah Lembaga yang disebut Mahkamah Konstitusi (MK). Dengan adanya MK masyarakat bisa mengadukan persoalannya yang tidak diakomodir oleh produk hukum yang 


\section{ALIRAN HUKUM \& BEKERJANYA HUKUM}

berlaku. Perkembangan Realisme di Indonesia mulai tahun 1990an semenjak merebaknya kekuatan civil society di Indonesia, dengan motor penggeraknya YLBHI (Yayasan Lembaga Bantuan Hukum Indonesia). Sementara dari perseorangan, pak Satjipto Rahardjo yang mengembangkan aliran Realisme dengan paradigma hukum progresif.

Dalam praktek peradilan pidana, kedua aliran tersebut mempunyai praktek yang sangat berbeda. Aliran positivism, perangkat hukumnya adalah; judge (hakim), lawyer (pengacara) dan atternoy (jaksa). Decision maker (pengambil keputusan) dalam sidang adalah Hakim, melalui sidang majelis hakim. Yang mengakibatkan hakim adalah seorang yang dipuja-puja kebenarannya dalam memutuskan perkara. Hakim adalah dewa dan "disembah" oleh para tersangka dan dihormati oleh pekerja hukum yang lainnya karena peranannya yang sangat besar dalam memutuskan sebuah perkara. Aliran Realisme, perangkat hukumnya tidak terpusat pada seorang hakim. Decision makernya ada pada jury, sekelompok perwakilan masyarakat yang terdiri dari berbagai profesi dan memiliki kapasitas untuk memutuskan perkara. Hakim berfungsi sebagai fasilitator yang berperan memberikan asistensi kepada para Jury tersebut, artinya kekuasaan tertinggi bukan pada hakim. Selain hakim dan jury, pekerja hukum yang lainnya sama dengan positivism,yakni aternoy (jaksa) yang mempunyai peranan penuntut umum.

Kedua aliran mempunyai sisi kelemahan dalam praktek pidana. Keterpusatan pada hakim ataupun pada jury, menyebabkan kedua pekerja hukum rawan aksi penyuapan oleh para tersangka. Hal tersebut menjadi sisi kelemahan kedua aliran. Menurut Bonaventura De Sausa Santos mengatakan bahwa ada tiga tahapan pada penyempurnaan berlakunya hukum di sebuah negara, yakni 1) the frontier; 2) the baroque; 3) the South. Pada tahap pertama (The Frontier) merupakan tahap awal berkembangnya masyarakat yang masih belum teratur dan masih berlaku hukum adat yang tidak terulis. Masyarakat sangat cair relasi sosialnya, hirarkhi sosial yang 
sangat lemah dan bercampurnya peninggalan sejarah dan penemuan baru dalam masyarakat. Bangunan masyarakat pada periode ini sangat lambat dan ruwet. Pada masyarakat seperti itu, tidak aturan yang secara tertulis berlaku, semuanya normatif dan identik dengan suasana "kacau balau".

Pada tahapan masyarakat yang kedua, digambarkan seperti design bangunan seni dan arsitektur pasca klasik pada abad ke-17 di Eropa atau design kebudayaan negara-negara di Amerika Latin. Bangunan ini merupakan bangunan yang sangat eksentrik dari sebuah kebudayaan modern. Pada tahap ini masyarakat sudah mempunyai kebudayaan dan sosial yang kreatif, mempunyai kodifikasi, mempunyai bangunan dan hukum yang nyata. Pada tahap ini berlaku hukum tertulis seperti apa yang kita kenal saat ini berupa produk undang-undang dan menunjukan suatu keteraturan.

Tahapan ketiga ini merupakan tahapan tertinggi suatu masyarakat karena peraturan yang berlaku di sebuah negara adalah tidak hanya untuk melanggengkan kekuasaan dari bangsawan, akan tetapai memberikan keadilan bagi kelompok yang tertindas juga. Hukum yang selama ini berlaku adalah hukum yang "mengeksploitasi dan tidak memberikan akses yang sama" bagi semua golongan dalam masyarakat. Hukum pada tahap The South mempunyai semangat perlawanan terhadap ketidakadilan tersebut.

\section{Bekerjanya Hukum}

Untuk bisa melihat bekerjanya hukum, kita awali dengan prosesproses sebuah hukum bisa berlaku menjadi sebuah peraturan yang berlaku di masyarakat;

\section{Pembuatan hukum}

Proses pembuatan hukum mempunyai hubungan dengan bekerjanya hukum sebagai suatu lembaga sosial, maka pembuatan hukum tersebut sebagai sebuah fungsi dalam masyarakat. Di dalam hubungannya dengan masyarakat dimana pembuatan 
hukum itu dilakukan, orang membedakannya dengan beberapa model. Menurut Chambliss dan Seidman dua model masyarakat tersebut adalah;

\section{1) Masyarakat yang berbasiskan kesepakatan akan nilai-nilai (value concensus)}

Masyarakat kategori ini minim sekali mengalami konflik karena atau ketegangan sebagai akibat dari adanya kesepakatan mengenai nilai-nilai yang menjadi landasan hidupnya. Unsurunsur yang menjadi pendukung kehidupan sosial itu dapat terangkum dalam satu kesatuan yang laras (well integrated). Di dalam masyarakat tersebut masalah yang dihadapi oleh pembuatan hukum hanyalah menetapkan nilai-nilai apakah yang berlaku dalam masyarakat itu. Pembuatan hukum merupakan pencerminan nilai-nilai yang disepakati oleh warga masyarakat.

\section{2) Masyarakat yang berdasarkan Konflik}

Pada model ini masyarakat dinilai sebagai suatu perhubungan dimana sebagian warga masyarakat mendapatkan tekanan dari sebagian masyarakat yang lain. Pembuatan hukum tidak berdasarkan pada nilai-nilai yang berkembang di masyarakat.

\section{Bekerjanya Hukum di Pengadilan}

Dilihat dari kaitan sosialnya, setiap pengadilan itu merupakan respon dari susunan masyarakat yang menjadi landasannya. Pengadilan yang dimaksud adalah sebagai pranata sosial untuk menyelesaikanya sengketa yang terjadi di masyarakat. Berdasarkan pranata yang digunakan oleh masyarakat untuk menyelesaikan masalah, Chambliss menyebutkan ada dua unsur yang menentukan;

1) Tujuan yang hendak dicapai untuk menyelesaikan sengketa. Apabila hendak mendamaikan orang yang bersengketa maka cara yang dilakukan adalah mendamaikan 
2) Tingkat perlapisan yang ada di dalam masyarakat, semakin tinggi tingkat perlapisan yang ada di dalam masyarakat, semakin besar pula perbedaan kepentingan dan nilai-nilai yang terdapat disana. Berdasarkan dua unsur tersebut menunjukan, bahwa masyarakat yang kurang berlapis dan kurang kompleks maka penyelesaian yang dilakukan lebih dipilih cara perukunan dan begitu pula sebaliknya.

Berdasarkan bagan berikut ini;

\section{Tabel.1 Pranata Yang Digunakan Masyarakat Untuk Menyelesaikan Masalah}

\begin{tabular}{|l|l|l|}
\hline & \multicolumn{1}{|c|}{$\begin{array}{c}\text { Masyarakat kurang } \\
\text { komplek }\end{array}$} & Masyarakat Komplek \\
\hline $\begin{array}{l}\text { Masyarakat kurang } \\
\text { berlapis }\end{array}$ & $\begin{array}{l}\text { Perukunan } \\
\text { Perukunan }\end{array}$ & $\begin{array}{l}\text { Penerapan hukum } \\
\text { perukunan }\end{array}$ \\
\hline Masyarakat berlapis & $\begin{array}{l}\text { Perukunan } \\
\text { Penerapan hukum }\end{array}$ & $\begin{array}{l}\text { Penerapan hukum } \\
\text { Penerapan hukum }\end{array}$ \\
\hline
\end{tabular}

Sumber: Satjipto, 1995

Unsur-unsur yang perlu diperhatikan berkaitan dengan pengolahan sebuah sengketa di pengadilan;

1) Cara-cara bagaimana persoalan itu bisa sampai di pengadilan

Syarat dasar bagi persoalan sampai pengadilan; pengetahuan tentang hukum dan kemampuan keuangan. Baik perkara pidana dan perdata, tetapi mayoritas perkara pidana. Masuknya perkara pidana tergantung dari lembaga-lembaga hukum yang bertugas menangani perkaranya, misalnya kepolisian. Secara umum, kepolisian lebih mudah memperkarakan orang miskn daripada orang kaya karena keterbatasan sumber ekonomi dan politiknya.

\section{2) Sumber-sumber teori}




\section{3) Atribut-atribut pribadi hakim}

Seorang hakim mempunyai peran sebagai berikut; pengemban nilai-niali yang dihayati oleh masyarakat, hasil pembinaan masyarakat dan menjadi obyek pengaruh pada massanya. Secara umum hakim itu berasal dari pembinaan oleh hakim senior sebelumnya dengan mempertahankan nilainilai yang dianutnya. Menurut Dahrendoorf, mayoritas hakim berasal dari kelas atas, sehingga jika menangani kasus kelas menengah ke bawah, merupakan dunia yang lain bagi seorang hakim dan bisa jadi sebuah ancaman bagi dirinya.

\section{4) Sosialisasi profesional hakim}

Pendidikan sarjana hukum di Indonesia itu masih menekankan pada keterampilan untuk menerapkan hukum bukan untuk melakukan pembaharuan hukum, berbuat kreatif, mencari alternatif-alternatif pengaturan yang lebih sesuai dengan perkembangan dan kebutuhan masyarakat.

\section{5) Tekanan-tekanan keadaan terhadap hakim}

Kondisi sosial menempatkan hakim pada posisi yang paling tinggi di dalam setiap aspek kehidupan. Seorang hakim memilki privilege yang tinggi dibandingkan dengan masyarakat yang bekerja di sektor pekerjaan yang lain.

\section{6) Tekanan-tekanan keorganisasian terhadap hakim}

Pengadilan merupakan lembaga yang mengemban tugas untuk mewujudkan tujuan-tujuan hukum, sehingga mereka mengembangkan kehidupan sendiri, membentuk normanorma sendiri untuk mewujudkan tujuannya sendiri pula. Sehingga pengadilan pun juga dituntut untuk melakukan kegiatan yang bersifat rasional ekonomis dengan pertimbanganpertimbangan sebagai berikut;

a. Berusaha untuk mendapatkan keuntungan secara maksimal bagi lembaganya

b. Berusaha menekan sampai batas minimal, beban-beban 
yang menekan organisasinya

c. Alternatif-alternatif peraturan yang bisa dipakai (Satjipto, 1995)

\section{Pelaksanaan Hukum (Hukum sebagai Suatu Proses)}

Hukum diciptakan untuk dijalankan. Menurut Scholten; hukum yang tidak pernah dijakankan pada hakikatnya telah berhenti menjadi hukum. Hukum juga bukan dari keluaran pabrik yang begitu keluar langsung bisa dipakai. Akan tetapi perlu dipersiapkan piranti untuk mendukungnya. Itu artinya hukum hanya bisa berjalan jika ada manusia, yang sekaligus juga mencipakan hukum itu sendiri. Disinilah peranan sosiologi hukum, yang memandang bahwa hukum itu bukan hanya seperangkat peraturan yang bersifat statis akan tetapi sebagai sebuah proses. Hukum itu tampak pada sidang-sidang pengadilan, dalam tindakan para pejabat atau pelaksana hukum, dalam kantor-kantor pengusaha dan juga dalam hubungan-hubungan yang dilakukan oleh dan diantara para anggota masyarakat satu sama lain (Soerjono Soekanto, 1976).

Apakah hukum yang dijalankan oleh masyarakat adalah cerminan dari hukum yang dituangkan dalam peraturan? Roscoe Pound membuat pembedaan antara law in book and law in action. Pembedaan itu mencakup hal-hal sebagai berikut; apakah hukum yang berlaku dalam bentuk peraturan yang diundangkan itu mengungkapkan pola tingkah laku sosial yang ada pada waktu itu, apakah yang dikatakan oleh pengadilan itu sama dengan apa yang dilakukan olehnya, apakah tujuan yang secara tegas dikehendaki oleh sutau peraturan itu sama dengan efek peraturan itu dalam kenyataan (Edwin, 39). Menurut Van Doorn, dalam setiap pengorganisasian itu banyak kita dapati manusia itu terjatuh pada luar bagian yang telah ditetapkan. Perbuatan manusia tersebut sangat sulit untuk didisiplinkan oleh organisasi karena masyarakat yang diwajibkan untuk menaati bagan tersebut memiliki latar 
belakang yang berbeda; kepribadian, asal usul sosial, kepentingan ekonomi dan politik serta pandangan hidupnya.

\section{Hukum dan Nilai-Nilai di Masyarakat}

Pembahasan mengenai pola-pola penyelenggaraan hukum oleh badan-badan yang diberi tugas untuk melaksanakan hukum telah memperlihatkan hal penyimpangan antara produk hukum dan pelaksanaannya. Hukum berupaya untuk menetapkan pola hubungan antara masyarakat dan merumuskan nilai-nilai yang diterapkan oleh masyarakat menjadi bagan atau stereotype (Soekanto, 1976). Sehingga hal ini berhubungan dengan nilai dan norma yang berkembang di masyarakat. Norma menurut Parson adalah suatu deskripsi tertulis mengenai perbuatan yang konkret dan dipandang sebagai suatu perbuatan yang diinginkan, sedangkan nilai diartikan sebagai suatu pernyataan tentang hal yang diinginkan oleh seseorang.

Menurut Lon L. Fuller hukum itu adalah sebagai sebuah usaha untuk mencapai tujuan tertentu. Usaha tersebut tergantung pada energi, wawasan, intelegensi dan kejujuran dari mereka yang menjalankan hukum. Delapan nilai yang harus dimiliki oleh hukum yang disebut sebagai delapan prinsip legalitas, adalah;

a. Harus ada peraturan yang terlebih dahulu, artinya tidak ada tempat bagi keputusan ad hoc atau tindakan arbitrer

b. Peraturan itu harus diumumkan kepada khalayak

c. Peraturan tersebut tidak berlaku surut

d. Perumusan peraturan-peraturam itu harus jelas dan terperinci (mudah dimengerti)

e. Hukum tidak boleh meminta dijalankannya hal-hal yang tidak mungkin

f. Diantara peraturan tidak boleh ada pertentangan antara satu peraturan dengan peraturan yang lainnya

g. Peraturan tersebut harus tetap dan tidak boleh sering diubah-ubah 
h. Harus terdapat kesesuaian antara pejabat hukum dengan peraturan yang dibuatnya

Kegagalan menjalankan salah satu dari asas hukum tersebut disebut sebagai sistem hukum yang jelek.

Fungsi hukum adalah sebagai berikut; melayani kebutuhankebutuhan elementer bagi kelangsungan kehidupan sosial (mempertahankan kedamaian, menyelesaikan sengketa, meniadakan penyimpangan). Singkatnya untuk menjaga ketertiban dan kontrol sosial. Pendapat lain menyatakan bahwa hukum adalah suatu lembaga di dalam masyarakat yang menegakan ketertiban dan menjalankan kontrol, sehingga di dalam hukum itu harus memiliki nilai-nilai tersendiri yang harus diwujudkan. Semakin masyarakat mengaitkan hukum dengan nilai-nilai yang harus diwujudkan, maka semakin besar fungsi hukum itu dalam melindungi hak-hak manusia. Selznick mengatakan hukum dengan latar belakang masyarakat yang menganut nilai-nilai tertentu. Misalnya; demokrasi.

Telaah tentang hukum yang dikaitkan dengan nilai-nilai serta sikap-sikap terhadap sistem hukum dikembangkan menjadi konsep kultur hukum yang membedakan dengan sistem hukum. Sistem hukum lebih berfokus pada prosedur yang lebih menunjukan pada konsepsi hukum prosedural. Sistem hukum ada 2 macam; common law dan civil law (indoskripsi.com).

Friedman merumuskan Kultur Hukum sebagai berikut; sikapsikap dan nilai-nilai yang berhubungan dengan hukum, bersama dengan sikap-sikap dan nilai terkait dengan tingkah laku yang berhubungan dengan hukum dan lembaga-lembaganya baik secara positif atau negatif. Berhubungan dengan ini, ketika kita mengamati bekerjanya hukum, maka kita harus melihatnya sebagai suatu proses, yakni apa yang dikerjakan oleh lembagalembaga hukum dan bagaimana mereka melakukannya. Sehingga kita bisa melihat hukum diluar dari kerangka hukum itu sendiri, tetapi nilai-nilai dan norma yang ada di masyarakat. 


\section{ALIRAN HUKUM \& BEKERJANYA HUKUM}

Komponen untuk melihat bekerjanya hukum;

\section{1) Struktural}

Ia adalah kelembagaan yang diciptakan oleh sistem hukum itu dengan berbagai macam fungsinya untuk mendukung bekerjanya sistem hukum. Secara struktural ini dapat melihat bagaimana sistem hukum itu memberikan pelayanan terhadap penggarapan-penggarapan bahan hukum secara teratur. Misalnya; ada pengadilan negeri, tinggi, administrasi atau agama

\section{2) Kultural}

Komponen ini terdiri dari nilai-nilai dan sikap-sikap yang merupakan pengikat sistem itu serta menentukan tempat sistem hukum itu ditengah-tengah kultur bangsa sebagai keseluruhan. Kultural hukum berfungsi untuk bensinnya motor keadilan

\section{3) Substantif}

Komponen ini adalah segi output sistem hukum, ke dalam pengertian ini dimasukan norma-norma hukum itu sendiri baik berupa peraturan-peraturan, doktrin-doktrin, keputusan-keputusan. Komponen substantif ini tidak terikat pada formalitas tertentu, apakah undang-undang ataupun peraturan. Yang dipentingkan apakah ia digunakan di dalam masyarakat.

Ketiganya menyatu dan saling berinteraksi dan membentuk sistem hukum (Satjipto, 1995). 
BAB II

Memahami Sosiologi Hukum 


\section{Pengertian Sosiologi Hukum}

Sebelum kita membahas tentang apa itu sosiologi hukum,

Skita perlu menguraikan dua ilmu pengetahuan yang berbeda tersebut, yakni sosiologi dan hukum. Mengingat sosiologi hukum tersebut seolah-olah berasal dari dua hal yang berbeda dan digabungkan menjadi satu ilmu pengetahuan baru yang akan kita pelajari selama satu semester ini, yakni sosiologi hukum.

Sosiologi merupakan cabang sosial science. Menurut J. Bierrens de Haan; Sosiologi adalah ilmu tentang pergaulan hidup atau ilmu yang menyelidiki masyarakat dari sudut pergaulan; Prof. Djojodiguno; sosiologi memiliki sasaran untuk mempelajari hidup bermasyarakat ; Lester F. Ward dan William Summer; sosiologi adalah ilmu tentang masyarakat. Emile Durkheim; sosiologi adalah "the sciences of institutions". George Simmel; sosiologi adalah ilmu pengetahuan yang mempelajari human relationships; M. Kovalevsky; sosiologi adalah "the science of sosial organization and sosial change" (Adham Nasution, 1983 :1); Pitirim A. Sorokin; "sociology is a generalizing science of socio kultural phenomena viewed in their generic form, types and manifold interconection" (P.A.Sorokin, 1974:1). Menurut Weber, sosiologi haruslah sebuah ilmu, memusatkan perhatian pada kausalitas dan menggunakan pemahaman yang interpretatif (verstehen) (Ritzer, 2008).

Sementara itu hukum adalah norma dan kekuasaan yang sengaja 
dibuat oleh pemerintah (datang dari atas) dengan tujuan untuk mengubah masyarakat. Hukum adalah kumpulan peraturan atau kaidah yang mempunyai isi yang bersifat umum dan normatif. Umum karena berlaku bagi setiap orang. Normatif karena menentukan apa yang seharusnya dilakukan, apa yang tidak boleh dilakukan, serta pelaksanaannya. Hukum yang dimaksud adalah hukum positif (sebagai acuan dalam berhukum di suatu negara).

Perbedaan sosiologi dan hukum adalah sebagai berikut; sosiologi adalah sebuah ilmu yang tidak normatif, bebas nilai dan netral, teori kemungkinan, pendekatan masalah adalah fakta-fakta sosial saat ini dengan perspektif masa depan, obyek studi masyarakat secara kolektif, kajian bersifat deskriptif (menjelaskan), menganalisis bahwa das sollen tidak sesuai dengan das sein, putusan yang bersifat kompromistis, pilihan satu diantara dua atau tiga pilihan dengan hipotesisnya masing-masing.

Sedangkan hukum berisikan nilai dan norma yang berlaku di masyarakat (normatif), pendekatan masalah adalah fakta-fakta sosial saat ini dan masa lalu yang bisa dibuktikan kebenarannya, obyek studi adalah individu di dalam masyarakat. Kajian hukum bersifat preskriptif (mengharuskan/memerintah), kaidah hukum lebih mementingkan das sein (apa yang seharusnya terjadi) daripada das sollen (apa yang senyatanya terjadi), putusan hakim bersifat ini, itu atau tidak sama sekali.

Mengapa sosiologi mempelajari hukum atau hukum juga mempelajari ilmu sosial? Sosiologi berkembang atas dasar suatu anggapan bahwa proses hukum berlangsung di dalam satu jaringan atau sistem sosial di dalam masyarakat (Soerjono Soekanto, 1974; 4) dan pandangan sosiologi; hukum adalah gejala sosial (terkait, setiap anggota masyarakat mempunyai kepentingan). Ditinjau dari hukum, adanya hakekat sosial hukum dari tata hukum. Hukum lahir sebagai proses sosial. Hukum sebagai sosial control atau alat pengendalian sosial, Menurut Roscoe Pound, hukum as tool of sosial engineriing (sarana pembaharu dalam masyarakat). Apabila digambarkan relasi kedua ilmu tersebut adalah sebagai berikut: 


\section{Bagan.1 Hubungan Antara Ilmu Hukum dan Sosiologi}

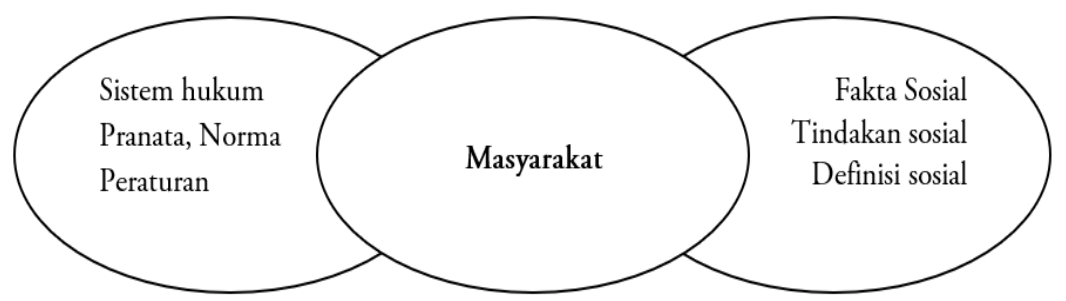

Sumber: Soerjono Soekanto, 1976

Berdasarkan bagan tersebut diatas, hubungan antara ilmu hukum dan ilmu sosial tidak bisa dipisahkan karena keduanya mempunyai hubungan yang erat dengan subyek dan obyek pembahasan yakni masyarakat. Ilmu hukum tidak bisa dipisahkan dengan masyarakat karena adanya living law dan ilmu sosial sendiri pun juga menganalisis tentang fenomena sosial masyarakat. Sehingga sosiologi hukum sebagai sebuah ilmu sangat diperlukan untuk menganalisis bekerjanya hukum di masyarakat.

Masyarakat yang sangat komplek membutuhkan aturan untuk mengatur dan menjalankan sistem kemasyarakatan. Sehingga terdapat banyak aturan yang ada di masyarakat, yang banyak dikenal; kaidah kesusilaan, sopan santun, agama, adat dan kaidah hukum. Perbedaannya adalah sebagai berikut;

\section{Tabel.2 Kaidah yang Berlaku di Masyarakat}

\begin{tabular}{|c|c|c|c|c|}
\hline & $\begin{array}{l}\text { Kaidah } \\
\text { Keper- } \\
\text { cayaan }\end{array}$ & $\begin{array}{l}\text { Kaidah } \\
\text { Kesusilaan }\end{array}$ & $\begin{array}{l}\text { Kaidah } \\
\text { Sopan } \\
\text { Santun }\end{array}$ & Kaidah Hukum \\
\hline Tujuan & \multicolumn{2}{|c|}{$\begin{array}{l}\text { Umat Manusia; Penyem- } \\
\text { purnaan manusia; jangan } \\
\text { sampai manusia jahat }\end{array}$} & \multicolumn{2}{|c|}{$\begin{array}{l}\text { Pembuatnya konkret; ketertiban } \\
\text { masyarakat; jangan sampai ada } \\
\text { korban }\end{array}$} \\
\hline Isi & \multicolumn{2}{|c|}{$\begin{array}{l}\text { Ditujukan kepada sikap } \\
\text { batin }\end{array}$} & \multicolumn{2}{|c|}{ Ditujukan kepada sikap lahir } \\
\hline Asal Usul & Dari Tuhan & $\begin{array}{l}\text { Dari diri } \\
\text { sendiri }\end{array}$ & \multicolumn{2}{|c|}{$\begin{array}{l}\text { Kekuasaan dari luar yang me- } \\
\text { maksa }\end{array}$} \\
\hline
\end{tabular}




\begin{tabular}{|l|l|l|l|l|}
\hline Sanksi & Dari Tuhan & $\begin{array}{l}\text { Dari diri } \\
\text { sendiri }\end{array}$ & $\begin{array}{l}\text { Dari } \\
\text { masyarakat } \\
\text { secara tidak } \\
\text { resmi }\end{array}$ & $\begin{array}{l}\text { Dari Masyarakat } \\
\text { secara resmi } \\
\text { (negara) }\end{array}$ \\
\hline $\begin{array}{l}\text { Daya } \\
\text { Kerja }\end{array}$ & Membebani Kewajiban & & $\begin{array}{l}\text { Membebani } \\
\text { kewajiban dan } \\
\text { memberi hak }\end{array}$ \\
\hline
\end{tabular}

Sumber: Sudikno Mertokusumo, 1999

Pembagian hukum menurut isinya;

1. Hukum privat (sipil); hukum yang mengatur hubungan antara orang yang satu dengan yang lain, dengan menitikberatkan kepentingan perseorangan. Terdiri atas;

2. Hukum sipil; hukum perdata dan hukum dagang

3. Hukum sipil; hukum perdata saja (secara umum orang mengatakan bahwa hukum perdata sama dengan hukum sipil)

4. Hukum publik (hukum Negara), yaitu hukum yang mengtaur hubungan antar negara dengan alat perlengkapan atau hubungan antara negara dengan perseorangan (warga negara); terdiri atas;

1) Hukum tata Negara-susunan pemerintahan suatu negara serta hubungan kekuasaan antara alat perlengakapan dan hubungan antara negara dan bagain negara (daerah).

2) Hukum Administrasi Negara (Hukum Tata Usaha Negara dan Tata Pemerintahan)

3) Hukum Pidana (pidana=hukuman), yaitu hukum yang mengatur perbuatan apa yang dilarang dan memberikan pidana kepada siapa saja yang melanggarnya serta mengatur bagimana cara mengajukan perkara ke muka pengadilan.

4) Hukum Internasional (Kansil, 24) 
Perbedaan Hukum Perdata dan Hukum Pidana; HUKUM PERDATA;

1. Mengatur hubungan hukum antara orang yang satu dengan orang yang lain dengan menitikberatkan kepada kepentingan perseorangan.

2. Pelanggaran terhadap norma hukum perdata dapat diambil tindakan oleh pengadilan setelah pengaduan oleh pihak yang berkepantingan yang merasa dirugikan

3. Hukum perdata memperbolehkan untuk mengadakan macammacam interpretasi terhadap UU Hukum Perdata

4. Hukum acara perdata yang menuntut si tergugat adalah pihak yang dirugikan. Penggugat berhadapan dengan tergugat

5. Dalam Acara Perdata, tergugat yang terbukti kesalahannya dihukum denda atau kurungan sebagai pengganti denda HUKUM PIDANA;

1. Mengatur hubungan hukum antara seorang anggota masyarakat (warga negara) dengan negara yang menguasai tata tertib masyarakat

2. Pelanggaran terhadap norma hukum pidana, pada umumnya segera diambil tindakan oleh pengadilan tanpa ada pengaduan dari pihak yang dirugikan. Pihak yang menjadi korban cukup mengadu ke kepolisian, pihak yang melapor menjadi saksi dan yang menjadi penggugat adalah jaksa (penuntut umum). Terhadap beberapa tindak pidana tertentu tidak diambil tindakan oleh pihak yang berwajib, jika tidak diajukan pengaduan oleh pihak yang yang dirugikan; perzinaan, perkosaan, pencurian

3. Hukum pidana hanya boleh ditafsirkan menurut arti kata dalam UU pidana itu sendiri

4. Hukum acara pidana inisiatif datang dari jaksa (penuntut umum)

5. Dalam Acara Pidana, terdakwa yang terbukti kesalahannya dipidana mati, penjara, kurungan atau denda, mungkin 
ditambah dengan pidana tambahan seperti dicabut hak-hak tertentu dan lain-lain (Kansil, 27).

Sosiologi hukum diperkenalkan pertama kali oleh Anzilotti, tahun 1882. Sosiologi hukum adalah cabang dari sosiologi yaitu merupakan penerapan pendekatan sosiologis terhadap realitas ataupun masalah-masalah hukum. Sosiologi hukum bukan cabang studi ilmu hukum. Cabang ilmu hukum yang berkaitan dengan sosiologi adalah sociological jurisprudence, yakni sebuah studi tentang karakteristik khusus dari ketertiban hukum. Pandangan ini lahir dari seorang ahli hukum yang mengamati masyarakat. Hal ini artinya ada semangat dari para juris untuk menganalisis dari segi sosialnya. Pandangan sosiologi hukum seperti ini pernah digunakan oleh Oliver W. Holmes (penganut aliran Realisme).

Sociological Jurisprudence adalah cabang dari ilmu hukum, disebut kajian yuridis normatif, cabang dari ilmu normatif, mempelajari bagaimana agar hukum menjadi efektif, proses pada logika (logic), pilihan praktis, tujuan dan pengambilan keputusan (decision) serta berdasarkan nilai subyektif.

Menurut definisi dari beberapa Ilmuwan tentang sosiologi hukum adalah sebagai berikut; 1) suatu ilmu teoritis yang berisikan generalisasi tentang fenomena masyarakat, sejauh yang menyangkut dengan substansi, aplikasi, dan akibat dari suatu aturan hukum (J.Hall); 2) suatu studi tentang hukum sebagai sarana kontrol sosial (Roscoe Pound); 3) sosiologi jiwa manusia yang mempelajari realitas sosial dari hukum secara lengkap, dimulai dari pengungkapan yang dapat diobservasi yang bersifat eksternal dan dapat berwujud,dalam suatu sikap kolektif yang efektif dan didasari atas dasar-dasar materil (George Gurvitch); 4) cabang ilmu pengetahuan yang secara analitis dan empiris menganalisis hubungan timbal balik antara hukum dengan gejala-gejala sosial lainnya (Soerjono Soekanto); 5) ilmu yang mempelajari hubungan timbal balik antara hukum dengan gejala-gejala sosial lainnya secara empiris analitis (R.Otje Salman); 6) pengetahuan hukum terhadap pola perilaku masyarakat dalam 


\section{MEMAHAMI SOSIOLOGI HUKUM}

konteks sosialnya, dengan karakteristik sebagai berikut;

1. bertujuan memberi penjelasan tentang praktik hukum, baik oleh hakim maupun dalam masyarakat. 2. Menguji keabsahan empiris dari suatu aturan hukum. 3. tidak melakukan penjelasan tentang hukum (Satjipto Rahardjo). Menurut Satjipto untuk mengetahui pemahaman sosiologi hukum untuk memotret gejala hukum dapat dengan mengajukan pertanyaan berikut ini;

1. Apakah hukum benar-benar mewujudkan kaidahnya dalam fakta masyarakat?

2. Apakah benar bahwa hukum itu mengatur masyarakat atau rakyat?

3. Apakah hukum menimbulkan efek sebagaimana yang dikehendaki hukum tersebut atau yang ditimbulkan justru efek yang berbeda atau tidak menimbulkan efek sama sekali?

4. Kalaupun ada efek yang ditimbulkan, apakah memang efek tersebut ditimbulkan oleh hukum?

5. Mengapa hukum menjadi seperti itu, apa tidak ada pengaturan alternatif yang lain atau memang harus begitu?

\section{Model Kajian Sosiologi Hukum}

Metode kajian sosiologi hukum dapat dikategorikan sebagai berikut, yakni;

\section{Kajian Konvensional}

Lebih menitikberatkan pada kontrol sosial yang dikaitkan dengan konsep sosialisasi (menjadikan individu sadar akan eksistensi aturan hukum di dalam pergaulan masyarakat)

\section{Kajian Kontemporer}

Pengkajian masalah-masalah yuridis empiris atas hukum dalam masyarakat yang heterogen dan multikultur 


\section{Obyek Kajian Sosiologi Hukum}

- Sosiologi hukum berobyekan hukum

Mengamati tentang hukum positif

- Sosiologi hukum berobyekan para pelaku hukum

Mengamati para pelaku/penegak hukumm (polisi hakim/judge, jaksa/atternoy, advokad/lawyer)

- Sosiologi hukum berobyekan pendapat orang mengenai hukum Mengamati pandangan masyarakat terhadap para penegak hukum Contoh Kajian Obyek Sosiologi Hukum;

- Hukum dan sistem sosial

- Hukum dan kekuasaan

- Hukum dan negara

- Hukum dan ekonomi

- Hukum dan nilai-nilai sosial budaya

- Struktur sosial dan hukum

- Hukum sebagai simbol

- Modernisasi hukum

- Kesadaran hukum dan perasaan hukum

- Hukum, kapitalisme, sosialisme, dan marxisme

- Hukum dan globalisasi

- Konflik sosial dan musyawarah

- Konsep stratifikasi

- Hukum dan ketidakadilan

- Kepastian dan kesebandingan hukum

- Efektivitas hukum

- Penerapan hukum di kepolisian dan kejaksaan

- Kontrol sosial melalui hukum

- Profesi hukum

- Pendidikan hukum

- Perbedaan antara das sollen dan das sein

- Fungsi hukum dalam membangun masyarakat

- Persamaan dan perbedaan antar sistem hukum 


\section{Letak Dan Ruang Lingkup Sosiologi Hukum}

- Dasar-dasar sosial atau basis sosial dari hukum

Misalnya; hukum nasional di Indonesia, dasarnya Pancasila, dengan ciri-cirinya; gotong royong dan musyawarah.

- Efek-efek hukum terhadap gejala sosial lainnya

Misalnya; Undang-undang perkawinan terhadap gejala kehidupan rumah tangga, Undang-undang Pilkada terhadap gejolak politik George Gurvitch, membagi Sosiologi Hukum;

\section{Sosiologi hukum Sistemik}

Mempelajari hubungan kenyataan sosial dan berbagai jenis hukum, dimulai dengan klasifikasi terhadap masyarakat

\section{Sosiologi hukum Genetik}

Mempelajari keteraturan sebagai kecenderungan perubahan bagi perubahan setiap tipe hukum dan mempelajari faktor yang menyebabkan transformasi dari keteraturan terhadap hukum

\section{Sosiologi hukum Diferensial}

Dimulai dengan mempelajari klasifikasi terhadap bentukbentuk kelompok masyarakat atau unit-unit kolektif

\section{Teori-Teori Dalam Sosiologi Hukum}

\section{Teori Klasik}

- Dipelopori oleh Eugen Ehrlich, dengan konsep living law

- Tempat hukum dan berkembangnya hukum bukanlah undang-undang atau doktrin, melainkan dalam masyarakat.

\section{Teori Makro}

- Dikembangkan oleh Max Weber dan Durkheim

- Adanya keterkaitan hukum dan bidang-bidang lain di luar hukum, seperti ekonomi, budaya dan politik kekuasaan 


\section{Teori Empiris}

- Hukum dapat diamati secara eksternal dengan mengumpulkan berbagai data dari luar hukum yang disebut perilaku hukum (behaviour of law), yang memunculkan dalil-dalil tertentu, misalnya;

1) Jumlah hukum meningkat seiring dengan menurunnya kontrol sosial di luar hukum

2) Hukum mempunyai korelasi dengan jarak sosial (keintiman di masyarakat)

3) Hukum berkorelasi dengan status orang yang menggunakan hukum

4) Jumlah peraturan bagi masyarakat yang berstatus tinggi, lebih tinggi daripada yang berstatus rendah

\section{Teori Sibernetika}

- Pelopor Talcot Parson, dengan teori struktural fungsional

- Membagi masyarakat menjadi beberapa subsistem (budayahukum,sosial,politik,dan ekonomi)

- Sektor hukum berada dalam budaya, yang berfungsi melakukan integrasi diantara proses-proses yang berlangsung dalam masyarakat sehingga tercapai ketertiban

Pengaruh Filsafat Hukum dan Ilmu Hukum terhadap Sosiologi Hukum;

1. Aliran Ilmu Alam (Aristoteles)

- Hukum dan moral

- Kepastian hukum dan keadilan

2. Madzab Formalisme (Hens Kelsen)

- Logika hukum

- Fungsi kekekalan dari hukum

- Peranan petugas hukum

3. Madzab Sejarah dan Kebudayaan (Von Savigny)

- Kerangka budaya dari hukum

- Hukum dan perubahan sosial 
4. Madzab Utilitarianisme dan Sosiological Jurisprudence (Roscoe Pound)

- Konsekuensi sosial dan hukum

- Klasifikasi tujuan makhluk hidup dan tujuan sosial

5. Madzab Sosiological Jurisprudence dan Legal Realism (Holmes)

- Hukum sebagai mekanisme pengendalian sosial

- Masalah hukum dan kebijakan hukum

- Faktor politis dan kepentingan dalam hukum

- Segi peri kemanusiaan hukum

- Telaah mengenai putusan pengadilan dan pola perilakunya

\section{Latar Belakang Lahirnya Sosiologi Hukum}

Sepanjang abad ke-19 dunia hukum dipengaruhi paham formalisme; hukum adalah ilmu pasti dan yang menjadi tokoh sentralnya adalah Langdell. Sosiologi hukum sebagai sebuah ilmu berkembang pada abad ke-20, pasca PD II dengan banyaknya permasalahan rasial. Artinya bahwa pelaksanaan hukum positif selama ini tidak menggunakan azas keadilan, akan tetapi lebih memberlakukan penghukuman terhadap masyarakat kulit hitam daripada kulit putih.

Donald Black, seorang sosiolog hukum dari Amerika mengatakan bahwa abad ke-20 adalah abadnya sosiologi (the age of sociology) (Satjipto, 2002). Gerakan hukum yang bersifat sosiologis ini mengembangkan dasar-dasar intelektual dan teoritikal terhadap sosiologi hukum. Gustav Radburg mengindikasikan pentingnya pendekatan masyarakat pada sektor hukum. Menurutnya ada tiga nilai hukum; keadilan, kegunaan, dan kepastian hukum, yang mana dalam kegunaan dari hukum tersebut menyebabkan studi tentang manfaat hukum bagi masyarakat menjadi sangat penting untuk dilakukan. Berkaitan dengan ilmu hukum sendiri merupakan bagian dari ilmu sosial, dengan obyeknya dunia nyata, filosofisnya pragmatisme dan fokus sentralnya proses pembuatan putusan pengadilan. 


\section{Pandangan Sosiologi terhadap Hukum}

1. Hukum merupakan refleksi dari kebiasaan, tabiat dan perilaku masyarakat

2. Hukum merupakan refleksi moralitas masyarakat maupun moralitas universal

3. Hukum merupakan refleksi dari kebutuhan masyarakat terhadap keadilandan ketertiban sosial dalam menata interaksi sosial di masyarakat

\section{Faktor Penyebab gerakan Hukum berorientasi Sosiologis}

Berkembangnya ilmu pengetahuan; aliran sejarah hukum, ilmu sosial (sosiologi), ilmu politik, filsafat hukum; Dinamika industrialisasi, urbanisasi, demokrasi, teknologi, dan globalisasi; Teori tradisional bahwa masyarakat merupakan suatu ikatan hubungan hukum; Berkembangnya hukum secara evolutif dari "status" (feodalistik) ke "kontrak" (modern); Analisis Durkheim dengan teorinya "rekonstruksi"; adanya perubahan dari masyarakat segmental (hak dan keawajiban pada unit yang tdk signifikan) ke fungsional (kesadaran kolektif/solidaritas organik); Hukum berubah dari represif menjadi restitutif.

\section{Prinsip Sosiologi Hukum;}

1. Hukum sebagai struktur normatif dibedakan dengan masyarakat sebagai kehidupan faktual dan sebagai aksi bersifat interelasi

2. Hukum dan masyarakat merupakan dua variabel independen (dipengaruhi karakter evolutif hukum)

3. Dapat dilakukan uji hipotesis yang empiris tentang hubungan antara hukum dan masyarakat

\section{Tahap perkembangan sosiologi hukum;}

1. Tahap Primitif/missioner

- Hukum merupakan wilayah tertutup

2. Tahap Keahlian dan Keterampilan Sosiologis

- Adanya kajian terhadap masyarakat dalam penelitian tentang hukum 


\section{MEMAHAMI SOSIOLOGI HUKUM}

3. Tahap Otonomi dan kematangan intelektual

- Fakta-fakta sosiologis dikaji dalam hukum secara mendalam

\section{Pemikiran dan perintis sosiologi hukum adalah;}

\section{EMILE DURKHEIM}

Pengaruh logika positivis sangat besar

- Konsepnya; kesadaran kolektif, pikiran kelompok, pemikiran kolektif dan solidaritas sosial

- Adanya pergerakan pararel antara hukum yang represif dan solidaritas mekanikal \& hukum yang restitutif dan solidaritas organik

- Hukum restitutif mengatur masyarakat dalam hubungan;

a. hubungan negatif

- Hubungan antara manusia dengan benda tertentu contoh; hak properti

\section{b. hubungan positif}

- Hubungan dalam masyarakat sebagai akibat pembagian kerja

- Semua hukum adalah hukum publik, semua hukum adalah sosial (all law is social)

\section{MAX WEBER}

- Konsepnya "herschaft", konsep yang bersifat subyektif, satu individu dengan yang lainnya saling mempengaruhi

- Seseorang dapat mendominasi yang lain, yang memberikannya kekuasaan

- Kekuasaan ini dalam hukum dinamakan "dominasi hukum"

- Dominasi hukum bangsa-bangsa ada empat tahap perkembangan;

a. Bentuk substantive irrational

a. Formal irrational (hukum tradisional)

a. Substantive rational

a. Formal rational (puncak perkembangan hukum) 
Dua kategori hukum;

a. Hukum yang dibuat (law making)

b. Hukum yang ditemukan (law finding)

- Sosiologi hukum adalah perbuatan individu yang diadaptasikan pada tatanan yang valid

- Hukum yang diinginkan Max Weber adalah hukum murni (pure law) dari Hans Kelsen

- Masalah sentral dalam Sosiologi hukum;

a. Hubungan hukum dan dominasi

b. Hubungan hukum dan struktur politik atau negara

c. Hubungan hukum dan sistem ekonomi

- Sosiologi hukum berhubungan antara sistem hukum dengan sistem sosial lain

\section{EUGEN EHRLICH}

- Konsepnya hukum yang hidup (living law) dan kehidupan hukum (legal life) yang merupakan dasar bagi suatu penemuan hukum yang bebas (free finding of law) agar hukum tertulis bisa mengadopsi kepentingan masyarakat

- Konsep living law;

a. Hukum memberi bentuk pada organisasi kemasyarakatan yang diorganisir masyarakat

b. Hukum tidak diciptakan oleh sanksi

c. Hukum bukan penyelesai konflik, tetapi ekspresi dari ketertiban faktual

d. Hukum bukan alat dari kekuasaan politik melainkan sarana perubahan sosial

e. Hukum bukanlah negara dan pengadilan bukan lembaga negara, tetapi hukum negara sangat dominan dalam hukum positif

\section{ROSCOE POUND}

- Konsepnya "sociological jurisprudence"

- Hukum sebagai alat rekayasa masyarakat (a tool of social 


\section{MEMAHAMI SOSIOLOGI HUKUM}

engineering)

- Hukum yang baik bersifat ideal-realistik, kombinasi dari paham idealisme dan pragmatisme;

a. unsur realitas sosial

b. elemen ideal berupa nilai spiritual 
BAB III

Pikiran Sosiologi Tentang Hukum 


\section{PIKIRAN SOSIOLOGI TENTANG HUKUM}

Pada bahasan ini terkait dengan tentang tokoh-tokoh sosiologi yang mempunyai sumbangan pemikiran terhadap sosiologi hukum.Tokoh-tokoh Sosiologi Klasik yang berpengaruh dalam perkembangan Sosiologi Hukum yaitu : Emile Durkheim, Max Weber dan Talcot Parson

\section{EMILE DURKHEIM}

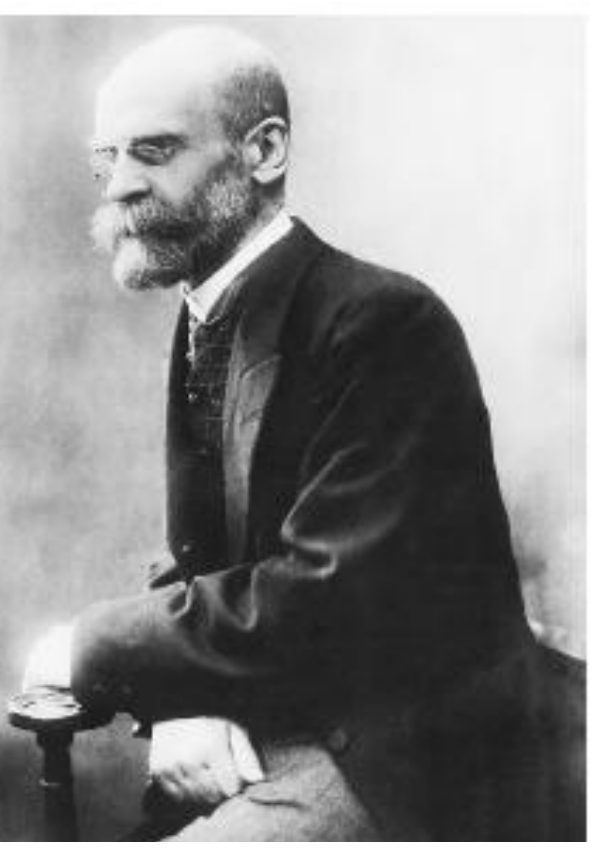

Gambar: Emile Durkheim

Karya Durkheim menekankan bahwa masyarakat lebih daripada sekadar jumlah dari seluruh bagiannya. Jadi berbeda dengan rekan sezamannya, Max Weber, memusatkan perhatian bukan kepada apa yang memotivasi tindakan-tindakan dari setiap pribadi (individualisme metodologis), melainkan lebih kepada penelitian terhadap "fakta-fakta sosial", istilah yang diciptakannya untuk menggambarkan fenomena yang ada dengan sendirinya dan yang tidak terikat kepada tindakan individu. Ia berpendapat bahwa fakta sosial mempunyai keberadaan yang independen yang lebih besar dan lebih objektif daripada tindakan-tindakan individu yang membentuk masyarakat dan hanya dapat dijelaskan melalui fakta-fakta sosial lainnya daripada, misalnya, melalui adaptasi masyarakat terhadap iklim atau situasi ekologis tertentu.

Dalam bukunya "Pembagian Kerja dalam Masyarakat" (1893), Durkheim meneliti bagaimana tatanan sosial dipertahankan dalam berbagai bentuk masyarakat. Ia memusatkan perhatian pada 
pembagian kerja, dan meneliti bagaimana hal itu berbeda dalam masyarakat tradisional dan masyarakat modern. Ia berpendapat bahwa masyarakat-masyarakat tradisional bersifat 'mekanis' dan dipersatukan oleh kenyataan bahwa setiap orang lebih kurang sama, dan karenanya mempunyai banyak kesamaan di antara sesamanya. Dalam masyarakat tradisional, kata Durkheim, kesadaran kolektif sepenuhnya mencakup kesadaran individual - norma-norma sosial kuat dan perilaku sosial diatur dengan rapi. Dalam masyarakat yang 'mekanis', misalnya, para petani gurem hidup dalam masyarakat yang swa-sembada dan terjalin bersama oleh warisan bersama dan pekerjaan yang sama. Ciri khas dari masyarakat tradisional ini adalah menghasilkan solidaritas mekanik bahwa solidaritas itu berdasarkan pada suatu tingkatan homogenitas yang tinggi dalam kepercayaan, sentimen dan lainnya. Homogenitas serupa hanya mungkin kalau pembagian kerja bersifat sangat minim (Johnson, 1986).

Dalam masyarakat modern, demikian pendapatnya, pembagian kerja yang sangat kompleks menghasilkan solidaritas 'organik'. Spesialisasi yang berbeda-beda dalam bidang pekerjaan dan peranan sosial menciptakan ketergantungan yang mengikat orang kepada sesamanya, karena mereka tidak lagi dapat memenuhi seluruh kebutuhan mereka sendiri. Dalam masyarakat modern yang 'organik', para pekerja memperoleh gaji dan harus mengandalkan orang lain yang mengkhususkan diri dalam produk-produk tertentu (bahan makanan dan pakaian) untuk memenuhi kebutuhan mereka. Akibat dari pembagian kerja yang semakin rumit ini, demikian Durkheim, ialah bahwa kesadaran individual berkembang dalam cara yang berbeda dari kesadaran kolektif, seringkali malah berbenturan dengan kesadaran kolektif.

Dalam karyanya "The Division of Labour in Society" ini juga, Durkheim mencoba mengkaji perbedaan antara hukum dalam masyarakat dengan solidaritas mekanik dan hukum dalam masyarakat dengan solidaritas organik (Cotteral, 1999). Ia menemukan bahwa masyarakat yang memiliki solidaritas mekanis hukum seringkali 


\section{PIKIRAN SOSIOLOGI TENTANG HUKUM}

bersifat represif: pelaku suatu kejahatan atau perilaku menyimpang akan terkena hukuman, dan hal itu akan membalas kesadaran kolektif yang dilanggar oleh kejahatan itu; hukuman itu bertindak lebih untuk mempertahankan keutuhan kesadaran. Hukuman tidak harus mencerminkan pertimbangan rasional yang mendalam mengenai jumlah kerugian secra obyektif yang menimpa masyarakat itu, juga tidak merupakan pertimbangan yang diberikan untuk menyesuaikan hukuman itu dengan kejahatannya. Sebaliknya hukuman itu mencerminkan dan menyatakan kemarahan kolektif yang muncul tidak terlalu banyak oleh sifat orang yang menyimpang atau tindakan kejahatannya seperti oleh penolakan terhadap kesadaran kolektif yang diperlihatkannya (Johnson, 1986).

Durkheim berpendapat bahwa masyarakat dengan solidaritas mekanik dibentuk oleh hukum represif. Karena anggota masyarakat jenis ini memiliki kesamaan satu sama lain dan karena cenderung sangat percaya pada moralitas bersama, apapun pelanggaran terhadap sistem nilai bersama tidak akan dinilai main-main oleh setiap individu. Karena setiap orang merasakan pelanggaran itu dan sama-sama meyakini moralitas bersama, maka pelanggar tersebut akan dihukum atas pelanggarannya terhadap sistem moral kolektif. Pencurian akan melahirkan hukuman berat. Meskipun pelanggaran terhadap sistem moral hanya pelanggaran kecil namun mungkin saja akan dihukum dengan hukuman yang berat (Ritzer, 2008).

Sebaliknya, dalam masyarakat yang memiliki solidaritas organik, hukum bersifat restitutif: ia bertujuan bukan untuk menghukum melainkan untuk memulihkan aktivitas normal dari suatu masyarakat yang kompleks (www.wikipedia.org). Masyarakat dengan solidaritas organis dibentuk oleh hukum restitutif dimana seseorang yang melanggar hukum harus melakukan restitusi untuk kejahatan mereka. Hukum restitutif berfungsi untuk mempertahankan dan melindungi pola saling ketergantugan yang kompleks antara berbagai individu yang berspesialisasi atau kelompok-kelompok dalam masyarakat. Tipe sanksi yang diberikan kepada seorang tersangka misalnya bukan 
untuk memberikan efek jera, melainkan untuk memulihkan keadaan (Johnson, 1986).

Dalam masyarakat seperti ini, pelanggaran dilihat sebagai serangan terhadap individu tertentu atau segmen tertentu dari masyarakat dan bukannya terhadap sistem moral itu sendiri. Karena kurangnya moral bersama, kebanyakan orang tidak melakukan reaksi secara emosional terhadap pelanggaran hukum. Para pelanggar hukum pada masyarakat organis akan dituntut membuat restitusi untuk siapa saja yang diganggu gugat kepentingannya. Meskipun dalam masyarakat ini ada hukum represif akan tetapi hukum yang bersifat restitutif lebih menonjol (Ritzer, 2008).

Dalam sistem organik, kemarahan kolektif yang timbul karena perilaku menyimpang menjadi kecil kemungkinannya, karena kesadaran kolektif itu tidak begitu kuat. Sebagai hasilnya hukum itu lebih bersifat rasional, disesuaikan dengan parahnya pelanggaran dan bermaksud untuk memulihkan atau melindungi hak-hak dari pihak yang dirugikan atau menjamin bertahannya pola saling ketergantungan yang kompleks itu, yang mendasari solidaritas sosial. Pola restitutif ini jelas terlihat pada hukum-hukum pemilikan, hukum-hukum kontrak, hukum perdagangan dan peraturan administratif dan prosedur-prosedur.

Jadi, perubahan masyarakat yang cepat karena semakin meningkatnya pembagian kerja menghasilkan suatu kebingungan tentang norma dan semakin meningkatnya sifat yang tidak pribadi dalam kehidupan sosial, yang akhirnya mengakibatkan runtuhnya yang mengatur perilaku. Durkheim menamai keadaan ini anomie. Dari keadaan anomie muncullah segala bentuk perilaku menyimpang, dan yang paling menonjol adalah bunuh diri (www.wikipedia.org).

\section{Catatan:}

Perkembangan hukum yang berlaku di masyarakat menunjukan tingkat perkembangan masyarakat tersebut sesuai dengan kondisi ekonomi dan politik mainstream. Hukum adalah manifestasi 


\section{PIKIRAN SOSIOLOGI TENTANG HUKUM}

dari persoalan laten ekonomi dan politik suatu Negara. Menurut Durhekim pembagian kerja yang ada di masyarakat (tentunya ditinjau dari segi ekonomi) mempengaruhi solidaritas yang terbentuk dan hukum yang berlaku. Hukum represif untuk masyarakat mekanik dan hukum restitutif bagi masyarakat organik.

Kondisi berlakunya suatu hukum tertentu adalah tahap perkembangan masyarakat itu sendiri. Artinya bahwa hukum yang berlaku di suatu negara tidak bisa dikatakan lebih baik atau lebih buruk dibandingkan dengan hukum yang belaku di negara yang lain. Semuanya adalah proses, kesadaran dan kebutuhan bersama terhadap peraturan yang seharusnya ditaati oleh semua kelompok dalam masyarakat itu sendiri.

Pada perkembangan masyarakat kita, masyarakat tradisional (pedesaan) tidak selalu menerapkan hukum represif, justru ada yang restitutif dan pada masyarakat modern (perkotaan, dengan pembagian pekerjaan yang tinggi) tidak juga menerapkan hukum yang bersifat restitutif akan tetapi justru sebaliknya. Hal ini yang perlu menjadi catatan bahwa kedua karakter masyarakat tersebut masih menerapkan hukum yang bersifat represif (bersifat menghukum dan memberikan efek jera), tidak bersifat restitutif (memulihkan dan mencegah keadaan). Mengapa hal ini bisa terjadi, apakah tahap perkembangan masyarakat kita adalah baru pada solidaritas mekanik ataukah hukum yang bersifat restitutif itu utopia belaka. 


\section{MAX WEBER}

Weber merupakan tokoh yang sangat berpengaruh di sosiologi karena karyanya banyak dan bervariasi, dapat ditafsirkan secara beragam sehingga sangat mempengaruhi banyak teori sosiologi. Karyanya mempengaruhi teori struktural fungsional melalui Talcot Parson, karyanya juga dianggap penting bagi tradisi konflik dan teori kritis yang sama-sama dibangun oleh Marx dan Weber. Ahli interaksi simbolik juga dipengaruhi oleh Weber dengan teori verstehen. Kalangan teoritikal pilihan rasional pun juga dipengaruhi oleh Weber (Ritzer, 2008).

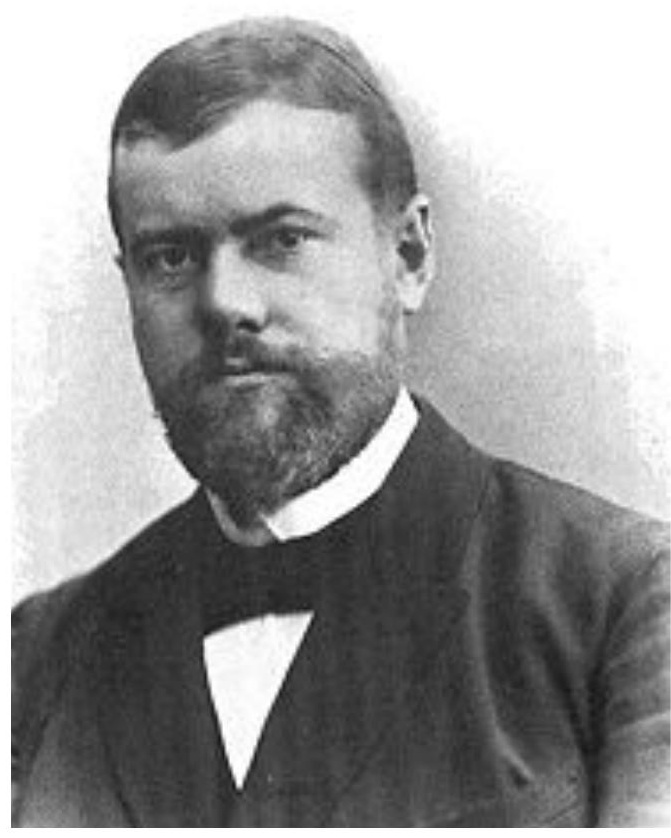

Gambar: Max Weber

Pada awalnya studi Weber adalah ilmu hukum dan menjalani kerja akademik pertamanya juga di bidang hukum. Kemudian dia bergeser memiliki ketertarikan yang luar biasa pada sosiologi dan sejarah. Berkaitan dengan analisisnya tentang hukum, tidak bisa dipisahkan pendapatnya tentang tindakan sosial. Dalam teori tindakannya, tujuan Weber tidak lain untuk memfokuskan perhatian pada individu, pola, regularitas hukum dan bukan pada kolektivitasnya. Tindakan dalam pengertian orientasi perilaku yang dapat dipahami secara subyektif hanya hadir sebagai perilaku seseorang atau beberapa orang manusia individual. Weber tidak mengelak bahwa sosiologi tindakan pada akhirnya berkutat pada individu, bukan kolektivitas (Ritzer, 2008). 


\section{PIKIRAN SOSIOLOGI TENTANG HUKUM}

Weber menggunakan metodologi tipe idealnya untuk menjelaskan makna tindakan dengan cara mengidentifikasi empat tipe tindakan dasar;

\section{Rasionalitas sarana-tujuan}

Atau disebut tindakan yang ditentukan oleh harapan terhadap perilaku obyek dalam lingkungan dan perilaku manusia lain; harapan-harapan ini digunakan sebagai syarat atau sarana untuk mencapai tujuan-tujuan aktor lewat upaya dan perhitungan yang rasional (Ritzer, 2008). Tingkat rasionalitas ini merupakan tahapan yang paling tinggi karena menyangkut pertimbangan dan pilihan yang sadar yang berhubungan dengan tujuan tindakan dan alat yang dipergunakan untuk mencapainya. Individu dilihat sebagai seseorang yang mempunyai tujuan-tujuan yang mungkin diinginkannya dan atas suatu kriteria menentukan satu tujuan diantara tujuan-tujaun yang saling bersaingan. Individu yang menentukan alat untuk mencapai tujuan tersebut. Pada akhirnya suatu pilihan dibuat atas dasar alat yang dipergunakan yang kiranya mencerminkan pertimbangan individu atas efisiensi dan efektivitasnya. Tindakan ekonomi pada sistem pasar merupakan bentuk dasar dari tindakan rasionalitas instrumental. Tipe tindakan ini juga tercermin pada organisasi birokratis yang ada saat ini (Johnson, 1986) .

\section{Rasionalitas nilai}

Tindakan yang ditentukan oleh keyakinan penuh atas kesadaran akan nilai perilaku-perilaku etis, estetis, religious atau bentuk perilaku lain, yang terlepas dari prospek keberhasilannya

\section{Tindakan Afektual}

Tindakan yang ditentukan oleh kondisi emosi aktor

\section{Tindakan Tradisional}




\section{SOSIOLOGI HUKUM \& KRIMINAL}

Tindakan yang ditentukan oleh cara bertindak aktor yang biasa dan telah lazim dilakukan

Tindakan-tindakan sosial yang dilakukan oleh individu mempengaruhi bangunan dasar untuk struktur-struktur sosial yang lebih besar, mulai dari tingkatan hubungan sosial, ke tingkat keteraturan ekonomi dan sosial politik. Stabilitas keteraturan sosial yang absah tidak tergantung semata-mata pada kebiasaan saja (uniformitas tidak diperkuat oleh sanksi eksternal) atau pada kepentingan diri individu yang terlibat. Sebaliknya keteraturan sosial didasarkan pada penerimaan individu akan norma-norma atau peraturan-pertauran yang mendasari keteraturan itu sebagai sesuatu yang diterima dan atau yang diinginkan. Norma atau peraturan tersebut bisa berdasarkan hukum atau konvensi. Pembedaan diantara keduanya adalah bahwa hukum tersebut diperkuat oleh sutau badan khusus, sedangkan konvensi didukung oleh tanggapan masyarakat di sekitarnya (Johnson, 1986).

Individu dapat menerima peraturan yang berlaku berdasarkan alasan yang berbeda-beda. Organisasi yang berbadan hukum, yang didirikan berdasarkan kepentingan kontraktual merupakan hubungan yang asosiatif (rasional) bukan komunal (emosional). Perhatian Weber yang utama adalah pada landasan keteraturan sosial yang absah, ini artinya bahwa keteraturan sosial dan pola-pola dominasi yang berhubungan dengan itu diterima sebagai sesuatu yang benar, baik oleh mereka yang tunduk pada dominasi atau mereka yang dominan.

Menurut Weber tiga dasar legitimasi yang digunakan untuk menggolongkan otoritas adalah sebagai berikut;

\section{Otoritas Legal Rasional}

Otoritas ini dianggap paling tertinggi tingkatannya, otoritas ini berdasarkan pada komitmen terhadap seperangkat peraturan yang dibuat secara resmi dan diatur secara impersonal. Orang yang mau melakukan otoritas ini karena dia memilki posisi 
sosial yang menurut peraturan yang sah dia didefinisikan sebagai memiliki posisi otoritas. Bawahan tunduk pada otoritas karena posisi sosial yang mereka miliki itu didefinisikan menurut peraturan sebagai yang harus tunduk dalam bidang-bidang tertentu. Artinya peraturan berhubungan dengan posisi serupa itu, bukan dengan orang yang kebetulan menduduki posisi itu. Otoritas legal rasional ini diwujudkan dalam bentuk organisasi birokrasi (Johnson, 1986).

\section{Otoritas Tradisional}

Tipe otoritas ini berdasarkan pada suatu kepercayaan yang mapan terhadap kekudusan tradisi-tradisi zaman dulu serta legitimasi status mereka yang menggunakan otoritas yang dimiliknya. Jadi alasan terpenting seseorang taat pada struktur otoritas adalah kepercayaan terhadap hal masa lalu yang selalu ada. Mereka menggunakan otoritas termasuk dalam satu kelompok status yang secara tradisional menggunakan otoritas atau yang dipilih sesuai dengan peraturan yang berlaku. Hubungan antara tokoh yang memilki otoritas dengan bawahannya pada dasarnya merupakan hubungan pribadi. Weber menggolongkan tiga otoritas tradisional; gerontokrasi, patriarchalisme dan patrimonialisme.

\section{a. Gerontokrasi}

Pengawasan berada pada pada orang-orang tua pada kelompok. Tidak memiliki staf administrasi.

b. Patriarchalisme

Pengawasan pada tangan satu satuan kekerabatan (rumah tangga) yang dipegang oleh seorang individu tertentu yang memiliki otoritas warisan. Memilki staf adminstrasi.

\section{c. Patrimonialisme}

Memiliki staf administrasi yang terdiri dari orangorang yang mempunyai hubungan pribadi dengan 
pemimpinnya. Pegawai-pegawai lahir di dalam administrasi rumah tangga si pemimpin. Para administrator pemerintah adalah pelayan pribadi dan wakil-wakil pemimpin.

\section{Otoritas Karismatik}

Otoritas ini berdasarkan pada mutu luar biasa yang dimiliki pemimpin itu sebagai seorang pribadi. Istilah charisma digunakan untuk menunjukan pada daya tarik pribadi yang ada pada diri seorang pemimpin. Dalam penggunaan Weber, hal itu meliputi karakteristik-karakteristik pribadi yang memberikan inspirasi pada mereka yang bakal menjadi pengikutnya. Dia juga menggunakan istilah ini untuk pemimpin umat beragama yang kharismatik dimana dasar kepemimpinan mereka adalah kepercayaan bahwa mereka memiliki suatu hubungan khusus dengan yang Ilahi atau malah mewujudkan karakteristikkarakteristil Ilahi tersebut (Johnson, 1986).

Tidak seperti sistem otoritas tradisional dan legal rasional, kepemimpinan karismatik tidak diorientasikan kepada hal-hal rutin yang stabil dan langgeng. Kalau otoritas tradisional diorientasikan untuk mempertahankan status quo, kepemimpinan karismatik biasanya menantang status quo. Pemimpin karismatik mengemukakan pesannya dengan rumusan tegas. Gerakan sosial yang dipimpin secara kharismatik bersifat tidak stabil dan mudah berubah-ubah yang biasanya muncul di luar kerangka kehidupan sehari-hari yang biasa dan dalam semangatnya bertentangan dengan apa yang rutin dalam kehidupan yang biasa tersebut (Johnson, 1986).

\section{Catatan:}

Sumbangan pemikiran Weber pada sosiologi hukum adalah tahap perkembangan masyarakat yang mencerminkan bagaimana hukum itu berlaku. Pada masyarakat yang memiliki tindakan 


\section{PIKIRAN SOSIOLOGI TENTANG HUKUM}

rasional dipengaruhi oleh otoritas tradisional, nilai dan kharismatik tentunya hukum yang berlaku berbeda dengan tahapan masyarakat yang memiliki rasionalitas sarana tujuan. Pada masyarakat ini bukan lagi konvensi dan hukum lisan yang berfungsi untuk menegakan peraturan dalam masyarakat, akan tetapi yang berlaku adalah hukum positif seperti yang kita kenal saat ini, yang produknya berupa undang-undang.

Birokrasi seperti yang kita kenal saat ini dalam berbagai macam bentuknya ataupun sistem ekonomi kapitalisme yang kita kenal memerlukan suatu regulasi yang tegas, teratur dan mengatur sistem keteraturan sosial secara rapi. Bentuk-bentuk organisasi sosial seperti ini ataupun tahapan masyarakat yang legal dan rasional ini merupakan kondisi yang tepat untuk berlakunya hukum positif.

\section{TALCOTT PARSON}

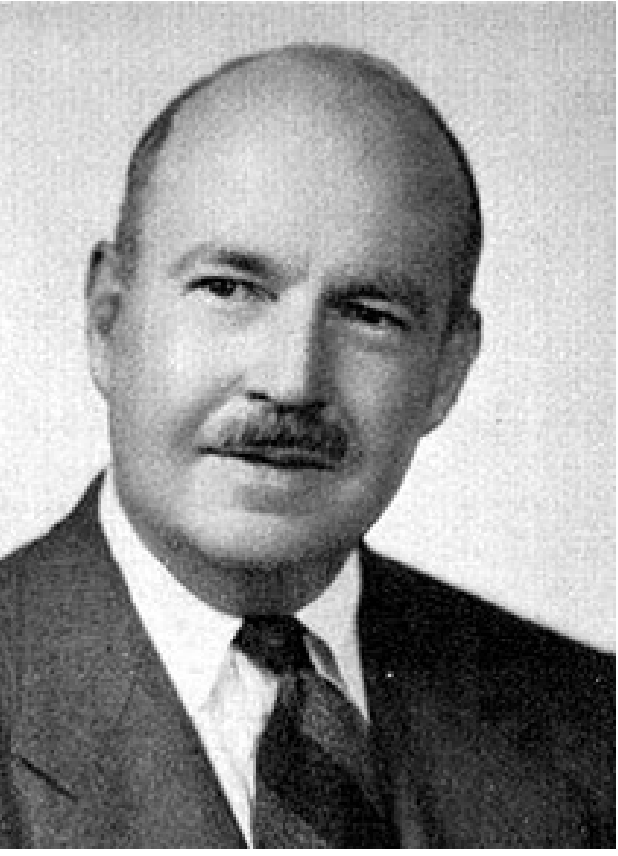

Gambar: Talcot Parson
Struktural fungsional merupakan aliran sosiologi yang dominan pada awal abad ke-19 yang tokohnya Talcot Parson dan Robert Merton. Kingsley Davis mengatakan bahwa dalam hal maksud dan tujuan, fungsionalisme struktural sinonim dengan sosiologi. Dalam fungsionalisme struktural, istilah struktural dan fungsional tidak boleh digunakan secara bersamaan, meskipun kedua-duanya adalah satu kesatuan. Kita dapat mempelajari struktur-struktur masyarakat tanpa membahas fungsinya (atau konsekuensi-konsekuensinya) bagi struktur lain. Senada dengan itu kita dapat menelaah fungsi dari berbagaiproses sosial yang 
mungkin saja tidak berbentuk struktural. Meskipun fungsionalisme struktural memiliki beragam bentuk. Fungsionalisme masyarakat adalah pendekatan dominan diantara para fungsionalis struktural sosial (Ritzer, 2008).

Menurut fokus ini, isu fungsional utamanya adalah bagaimana masyarakat memotivasi dan menempatkan orang-orang pada posisi tepat dalam sistem stratifikasi, yang dapat dikerucutkan menjadi dua masalah; 1). Bagaimana masyarakat memasukan hasrat untuk memasukai posisi tertentu pada individu-individu yang tepat. 2) begitu orang-orang pada posisi yang tepat, bagaimana masyarakat memberikan hasrat untuk memenuhi persyaratan-persyaratan posisi tersebut. Fungsionalisme struktural Parson ini mempunyai 4 imperatif fungsional bagi sistem tindakan, yakni skema AGIL; fungsi adalah suatu gugusan aktivitas yang diarahkan untuk memenuhi satu atau beberapa kebutuhan sistem. Empat imperatif fungsional yang diperlukan adalah A (adaptation)-adaptasi, G (goal attainment)pencapaian tujuan; I (integration)-integrasi dan L (Latency)pemeliharaan pola. Agar sebuah sistem bisa berjalan dan bertahan hidup, maka keempat imperatif fungsional tersebut harus berjalan bersama-sama;

1. Adaptasi, sistem harus mengatasi kebutuhan situasional yang datang dari luar. Ia harus beradaptasi dengan lingkungan dan menyesuaikan lingkungan dengan kebutuhan-kebutuhannya.

2. Pencapaian Tujuan, sistem harus mendefinisikan dan mencapai tujuan-tujuan utamanya.

3. Integrasi, sistem harus mengatur hubungan bagian-bagian yang menjadi komponennya, ia pun harus mengatur antara ketiga imperatif fungsional tersebut.

4. Latensi (pemeliharaan pola), sistem harus melengkapi, memelihara dan memperbarui motivasi individu dan pola-pola budaya yang menciptakan dan mempertahankan motivasi. 


\section{PIKIRAN SOSIOLOGI TENTANG HUKUM}

Dalam analisis strukturalnya Parson lebih banyak mengkaji tentang sistem sosial pada skala makro, yakni kolektivitas, norma dan nilai. Pada analisis sistemnya, dia juga seorang fungsionalis dengan prasyaratnya sebagai berikut;

1. Sistem harus terstruktur sehingga dapat beroperasi secara baik dengan sistem yang lain

2. Agar bisa bertahan hidup, sistem harus didukung oleh sistem yang lain

3. Sistem harus secara signifikan memenuhi kebutuhankebutuhan aktornya

4. Sistem harus menimbulkan partisipasi yang memadai dari anggota-anggotanya

5. Sistem harus mempunyai kontrol yang minimum terhadap perilaku yang merusak

6. Jika konflik mmejadi sesuatu yang menimbulkan kerusakan signifikan, ia harus dikontrol (Ritzer, 2008).

Pada akhirnya sistem memerlukan bahasa dan regulasi untuk menjalankan fungsinya

\section{Catatan:}

Struktural fungsionalisme mensyaratkan beberapa hal agar dapat terwujud sistem sosial yang bisa berjalan sesuai dengan kondisi yang seharusnya. Sistem sosial tersebut memerlukan aturan (hukum) yang berfungsi untuk menggerakan roda-roda sistem agar berjalan dengan baik. Secara eksplisit Parson memang tidak memberikan sumbangan pada sosiologi hukum, akan tetapi hanya secara global memberikan pendapat bahwa sistem sosial yang dapat berfungsi sesuai dengan fungsinya memerlukan prasyarat memperhatikan sistem yang lain sehingga berjalan seirama dengan harmoni kehidupan. Hukum itu lah yang diperlukan untuk menciptakan sebuah sistem sosial yang rapi, teratur dan ada mekanisme keseimbangan dengan sistem yang lain. Alat kontrol apabila terjadi konflik yang berada dalam sistem itu pula yang disebut dengan hukum yang sangat diperlukan dalam masyarakat. 


\section{BAB IV}

\section{Hukum Progresif}

(Disarikan dari Buku Satjipto

Rahardjo: Hukum Progresif dan

Membedah Hukum Progresif) 
$A$ da suatu pertanyaan yang berkaitan dengan hukum dan Aperaturan. Apakah ketertiban di masyarakat merupakan hasil dari bekerjanya hukum. Kita menganggap wajar, bila ketertiban disebabkan oleh karena adanya hukum; seperti perundang-undangan dan institusinya. Pikiran tersebut bersifat Hobbesian, dalam arti mempercayakan ketertiban masyarakat sepenuhnya kepada hukum yang hanya bisa dilahirkan oleh satu-satunya kekuasaan. Tanpa adanya kekuasaan absolut yang menguasai seluruh masyarakat, akan terjadi kekacauan, pertentangan antar anggota masyarakat. Maka, demi ketertiban dalam masyarakat, semua orang harus tunduk pada negara. Masyarakat ditelan habis oleh negara. Itulah menurut Hobbes, ongkos yang harus dibayar untuk mendaatkan ketertiban dalam masyarakat. Dalam konteks ini tidak ada ruang publik, yang ada hanya ruang bagi negara. Segala urusan ketertiban dalam masyarakat hanya bisa dilakukan melalui negara, karena itu harus diserahkan kepada hukum. Hukum adalah satu-satunya institusi yang mampu menuntaskan segalanya.

Akan tetapi kenyataan di masyarakat bahwa serahkan semuanya kepada hukum, maka segalanya akan beres, hanyalah mitos belaka. Bila dikatakan bahwa hukum akan menghentikan kejahatan melalui sanksi pidana yang diancamkan, itu hanya sebagian dari proses. Itu baru cita-cita atau harapan karena sesudah peraturan, masih diperlukan tindakan agar apa yang diinginkan oleh peraturan (hukum) menjadi kenyataan. Dalam proses hukum, masih ada polisi yang harus bertindak, masih diperlukan masyarakat yang 
mendukung keinginan hukum. Artinya hukum perlu bekerja sama dengan penegak hukum untuk menuntaskan sebuah perkara.

Salah satu contoh masyarakat yang sangat menjunjung hukum adalah AS yang mengenal Syndrom Kitty Genovese (SKG). Mereka beranggapan jika sudah ada hukum, mengapa kita harus susah-susah melibatkan diri? Kita sudah membayar pajak, biarkan saja polisi menyelesaikan permasalahan kejahatan. Apa yang dialami oleh Kitty Genovese, pada tahun 1960, dalam perjalanan pulang, perempuan itu dicegat oleh laki-laki di dekat apartemennya, diperkosa, lalu dibunuh. Walaupun dia berteriak-teriak, tidak ada satu orang pun di apartemen yang perlu turun tangan. Hukum yang dijunjung tinggi habis-habisan akan menghilangkan sifat kemanusiaannya dalam hukum. Hukum menjadi steril tanpa adanya kepedulian kemanusiaan. Sebaliknya di Indonesia, kaum legalis menyatakan adanya sindrom tindakan main hakim sendiri, sedangkan para sosiologi hukum mengatakan sebagai bentuk self help dari komunitas di situ. Lalu dimanakah kondisi yang ideal diantara keduanya? Hukum diatas segalanya atau solidaritas yang tinggi dalam berhukum.

\section{Negara Hukum}

Semenjak kita memproklamasikan kelahiran Negara hukum RI pada tanggal 17 Agustus 1945, maka pada waktu itu kita merasa sudah menjadi negara hukum yang sempurna secara formal, akan tetapi secara substansialnya masih jauh. Negara hukum yang ingin kita bangun berdasarkan Undang-Undang Dasar yang bertujuan untuk memajukan kesejahteraan umum dan mencerdaskan kehidupan bangsa. Sehingga negara hukum memikul beban yang sangat berat, yakni memandu bangsa ini menuju kepada kehidupan yang bahagia.

Negara hukum tidak instan, akan tetapi harus dibangun. Negara hukum adalah konsep modern yang tidak tumbuh dalam masyarakat Indonesia sendiri, layaknya perkembangan masyarakat di Eropa yang membutuhkan waktu 10 abad untuk menemukan sebuah konsep rule of law dan negara konstitusional yang diawali dari feodalisme, 
staendesstaat, negara absolut sampai negara konstitusional. Negara hukum di Indonesia adalah impor, dipaksakan dari luar (imposed from outside) melalui transformasi dan transplantasi, melalui lompatan dari feodalisme langsung menjadi negara hukum modern. Sehingga membangun negara hukum adalah membangun perilaku bernegara hukum dan membangun peradaban baru. Menjadi negara hukum yang sebenarnya adalah proses panjang karena menyangkut perubahan perilaku, tatanan sosial dan kultur. Hukum dan negara hukum modern membutuhkan suatu predisposisi sosial dan kultural tertentu untuk berhasil dengan baik. Salah satu persyaratan yang menonjol adalah ambruknya tatanan kolektif dan personal untuk digantikan dengan tatanan yang rasional dan impersonal. Sehingga semakin teralienasi manusia satu dengan yang lain, hukum modern semakin diperlukan. Semakin urban dan individual suatu masyarakat, maka semakin hukum itu dibutuhkan. Sebaliknya masyarakat dengan kehidupan kolektif dan solidaritas yang tinggi kurang memerlukan hukum.

Negara hukum tidak bisa direduksi menjadi negara undangundang atau lebih rendah lagi negara prosedur. Apabila itu yang terjadi, negara hukum Indonesia sudah kehilangan grandeur, keagungan dan kebesarannya. Negara hukum bukan hanya secarik dokumen, tetapi sesuatu proyek yang jauh melampaui dokumen kata-kata dan konsep. Sehingga penyelenggaraannya perlu diserahkan kepada orang-orang yang tercerahkan oleh ide besar bernegara hukum. Negara hukum juga perilaku bagi orang-orang yang melaksanakannya. Negara hukum yang diharapkan menjadi bangunan yang penuh grandeur dan berkah bagi rakyat manakala hukum dipahami dan dijalankan dengan kelengkapan logika; logika peraturan (membaca peraturan), logika kepatutan sosial (social reasonableness). Pada saat kita mempertimbangkan "apakah yang ingin kita lakukan sudah sesuai dengan kepatutan dalam masyarakat" dan logika keadilan (logika yang dapat diperoleh tidak hanya dengan membaca aturan, tetapi melakukan perenungan dan pemaknaan lebih dalam terhadap apa yang kita baca. Adilkah keputusan yang sudah dibuat? 
Karut marut hukum di Indonesia, bukan hanya ditinjau dari sisi hukum semata, artinya perhatian lebih diarahkan pada aspek perundang-undangan dengan melakukan amandemen, akan tetapi perlu juga diimbangi dengan gerakan penegakan supremasi hukum, yang selama ini berjalan di tempat.

Kehidupan hukum tidak hanya menyangkut urusan hukum teknis, seperti pendidikan hukum, tetapi menyangkut soal pendidikan dan pembinaan perilaku individu dan sosial yang lebih luas. Berdasarkan data empirik itu, dibangun konsep teori bahwa hukum bukan hanya urusan (a business of rules), tetapi juga perilaku (matter of behavior).

Menurut Hakim Agung, O.W.Holmes bahwa menjalankan hukum bukan hanya soal logika, tetapi juga pengalaman (the life of the law has not been logic but experience). Menurut Van Doorn, sosiolog hukum Belanda bahwa hukum merupakan skema yang dibuat untuk menata (perilaku) manusia, tetapi manusia itu sendiri sering terjatuh dari skema yang diperuntukan baginya. Hal ini disebabkan oleh faktor pengalaman, pendidikan, tradisi dan lainnya yang mempengaruhi dan membentuk perilaku. Faktor perilaku atau manusia sangat berpengaruh dalam kehidupan hukum. Ketika kita berbicara perilaku dalam hukum, maka hal yang perlu diperhatikan adalah aspek Human Capital, yang kita miliki hanya sedikit. Seseorang pernah menyatakan bahwa "berikan padaku hakim dan jaksa yang baik, maka dengan hukum yang buruk saya bisa mendatangkan keadilan. Dalam suatu dialog di TVRI, seorang anak muda ada yang mengatakan bahwa "selama UUD kita dijalankan oleh orang-orang yang berjiwa kerdil, maka impian dan cita-cita UUD tidak akan terwujud".

Selain Human Capital, kita juga memerlukan Social Capital dalam berhukum. Kita menyatakan bangsa Indonesia yang berbudi luhur, bermoral, bersifat kekeluargaan, kebersamaan dan semacamnya, akan tetapi hal tersebut tidak sampai pada kultur hukum kita. Kultur hukum kita cenderung individualistik. Social Capital merupakan tulang punggung untuk menjalankan kehidupan 
bernegara hukum. Jepang dan Amerika memilki Social Capital masing-masing sebagai pendukung Negara hukumnya. Jepang menekankan moral kolektivisme yang menjalankan hukum dengan hati nurani, sementara AS pada individualisme dan liberalisme yang sangat rasional dalam menjalankan hukum.

Kita bernegara hukum untuk apa? Apakah hukum itu hanya semata-mata untuk mengatur masyarakat ataukah untuk suatu tujuan yang lebih besar, yakni memberikan kebahagiaan kepada rakyat dan bangsanya. Hukum sebagai peraturan menempatkan rasionalitas diatas segalanya, sehingga dapat menghasilkan sebuah peraturan. Artinya hukum demi hukum. Akan tetapi tujuan hukum bukan pada itu, akan tetapi hukum lebih menginginkan mewujudkan keadilan dan kebahagiaan diatas segalanya. Itu yang kita dapat amati bagaimana orang Timur menjalankan hukum yang ada di negerinya.

Selain pemikiran rasionalitas, ada metode berpikir yang lain, yakni perasaan (mempertimbangkan lingkungan atau habitat sehingga tidak semata-mata logika dan spiritual (mencari makna dan nilai yang tersembunyi dibalik obyek yang ditelaah). Kecerdasan intelektual yang bersifat rasional selalu terikat pada patokan (rule bound) dan amat melekat pada program yang telah dibuat (fixed program) sehingga menjadi deterministic. Berpikir menjadi suatu finite game. Berpikir dengan perasaan lebih maju, karena tidak semata-mata menggunakan logika tetapi bersifat kontekstual. Sedangkan kecerdasan spiritual, tidak ingin dibatasi dengan patokan (rule bound), juga tidak hanya bersifat kontekstual, tetapi ingin keluar dari situasi yang ada dalam usaha untuk mencari kebenaran, makna, nilai yang lebih dalam. Dengan demikian berpikir menjadi suatu infinite game, tidak ingin diikat dan dibatasi patokan yang ada, tetapi ingin melampaui dan menembus situasi yang ada (transenden). Kecerdasan spiritual tidak berhenti menerima keadaan dan beku, tetapi kreatif dan membebaskan. Dalam kreativitasnya, ia mungkin bekerja dengan mematahkan patokan yang ada (rule breaking) sekaligus membentuk yang baru (rule making). Kecerdasan spiritual 
sama sekali tidak menyingkirkan kedua model yang lain, akan tetapi meningkatkan kualitasnya sehingga mencapai tingkat yang oleh Zohar dan Marshall disebut sebagai "kecerdasan sempurna".

Dalam kaitannya kehidupan hukum, kecerdasan spiritual tersebut muncul dalam menjalankan hukum, tidak semata-mata menerapkan huruf-huruf dalam peraturan begitu saja, tetapi mencari dan menemukan makna sebenarnya dari suatu peraturan. Paul Scholten, seorang Guru Besar di Belanda menyatakan bahwa hukum memang dalam undang-undang, akan tetapi masih harus ditemukan (finding law). Mencari hukum dalam peraturan adalah menemukan makna dan nilai yang terkandung dalam peraturan dan tidak hanya membacanya secara datar.

\section{Pengadilan Progresif (Kasasi)}

Kasasi pada tingkat pangadilan adalah tidak lagi membicarakan fakta, yang dilakukan adalah memeriksa apakah hukum yang telah dijalankan dengan benar ataukah tidak oleh pengadilan di tingkat bawah. Yang berhak melakukannya adalah MA, sehingga MA akan memeriksa apakah peraturan yang digunakan hakim di PN atau PT untuk menjatuhkan putusan sudah benar. Bila benar demikian, tidak akan ada pintu masuk bagi pengadilan progresif, proses yang sarat dengan compassion yang memuat empati, determinasi dan nurani.

Pengadilan progresif memiliki semboyan; hukum adalah untuk rakyat bukan sebaliknya. Dalam pengadilan progresif pun membutuhkan seorang hakim progresif bahwa hakim bukan hanya pembaca teks undang-undang semata, akan tetapi juga sebagai makhluk sosial. Hakim adalah representasi dari masyarakat, ia berbagi suka dan duka, kecemasan, penderitaan, harapan seperti apa yang dirasakan oleh masyarakat. Melalui putusan-putusannya, hakim mewakili suara masyarakat yang tidak terwakili (unrepresented) dan kurang terwakili (under-represented). Pekerjaan penegakan hukum tidak hanya ditentukan oleh faktor dari luar, tetapi juga dari dalam. Dalam hal ini dikemukakan ada 2 penegak hukum, sehingga 
melahirkan 2 macam penegakan hukum. Hal ini menunjukan bahwa hukum bukan hanya soal peraturan, akan tetapi keterlibatan manusia secara utuh. Jaksa yang berani dan membedakan dengan yang lainnya karena mereka selalu merujuk pada hati nurani.

\section{Pejabat Hukum Progresif}

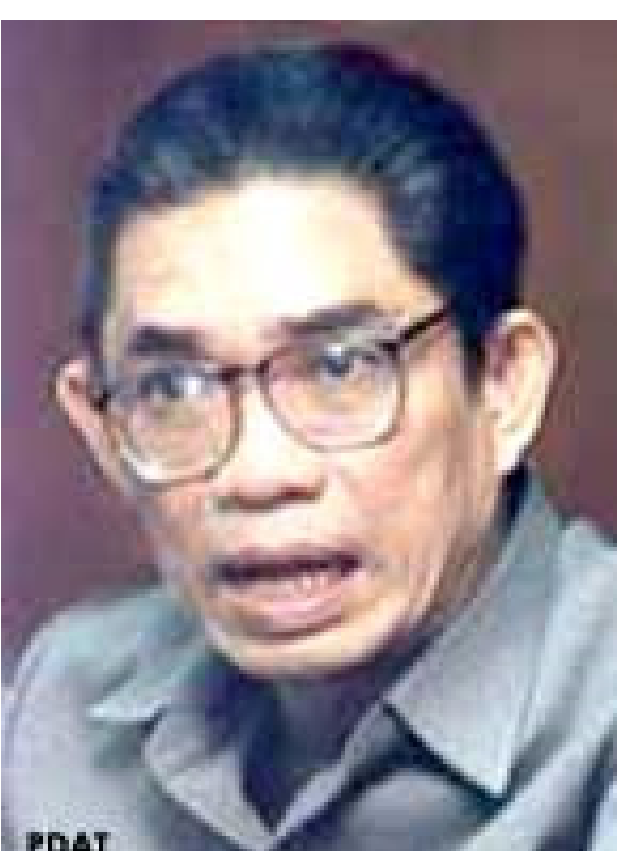

Gambar: Baharudin Lopa

\section{Baharudin Lopa}

Dalam menegakkan hukum dan keadilan, Lopa, jaksa yang hampir tidak punya rasa takut, kecuali kepada Allah. Dia, teladan bagi orang-orang yang berani melawan arus kebobrokan serta pengaruh kapitalisme dan liberalisme dalam hukum. Ketika menjabat Jaksa Tinggi Makassar, ia memburu seorang koruptor kakap, akibatnya ia masuk kotak, hanya menjadi penasihat menteri. Ia pernah memburu kasus mantan Presiden Soeharto dengan mendatangi temantemannya di Kejaksaan Agung, di saat ia menjabat Sekretaris Jenderal Komnas HAM. Lopa menanyakan kemajuan proses perkara Pak Harto. Memang akhirnya kasus Pak Harto diajukan ke pengadilan. Sejak menjabat Jaksa Agung, Lopa memburu Sjamsul Nursalim yang sedang dirawat di Jepang dan Prajogo Pangestu yang dirawat di Singapura agar segera pulang ke Jakarta. Lopa juga memutuskan untuk mencekal Marimutu Sinivasan. Namun ketiga konglomerat "hitam" tersebut mendapat penangguhan proses pemeriksaan langsung dari Wahid, alias Gus Dur. Lopa juga menyidik keterlibatan Arifin Panigoro, Akbar Tandjung, dan Nurdin Halid dalam kasus korupsi. Gebrakan Lopa itu sempat dinilai bernuansa politik oleh berbagai kalangan, 
namun Lopa tidak mundur. Lopa bertekad melanjutkan penyidikan, kecuali ia tidak lagi menjabat Jaksa Agung. Ketika menjabat Menteri Kehakiman dan HAM, ia menjebloskan raja hutan Bob Hasan ke Nusakambangan (dari berbagai sumber).

\section{Bismar Siregar}

Ibarat kaca, mantan hakim agung Bismar Siregar SH, menjadi cermin kebeningan hati nurani bagi para hakim. Mantan Ketua Pengadilan Tinggi Sumatra Utara (1984), ini selalu mengandalkan hati nurani setiap kali mengambil keputusan. Sebab baginya, hati nurani tidak bisa diajak berbohong. Dia merasa sangat bersyukur dan bahagia sekali tidak masuk lingkaran hakim yang bisa disuap atau dibeli. Karena itu Bismar Siregar, satu pendekar hukum langka yang berani melawan arus demi tegaknya keadilan. Baginya, undang-undang, hukum dan kepastian hukum, hanya sarana untuk mencapai keadilan.

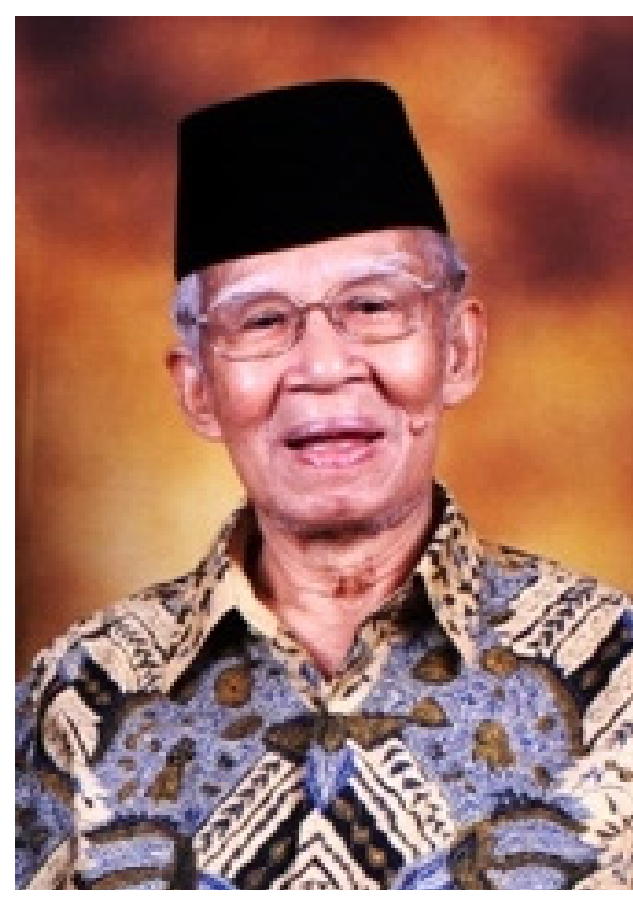

Gambar : Bismar Siregar

Untuk itu, Bismar selalu bertanya kepada hati nuraninya sendiri. Dia tidak ingin membohongi hati nuraninya ketika memutuskan suatu perkara. Setiap kali membuka berkas perkara atau memimpin sidang pengadilan, nurani keadilan selalu terbayang dibenaknya. Karena itu, kebanyakan teman menganggapnya sebagai hakim yang aneh, penuh kontroversi. Padahal duduk soalnya sederhana saja, Bismar tidak mau disuap, tidak bisa dibeli. Bismar selalu berdialog dengan hati nuraninya: "Salahkah orang ini? Jahatkah dia? Bagaimana hukumannya, berat atau ringan?”. Sesudah hati nuraninya 


\section{HUKUM PROGRESIF}

memutuskan, maka ia mencari pasal-pasal hukum sebagai dasarnya. Masih ada contoh lain. Bismar mengubah hukuman bagi seorang kepala sekolah yang mencabuli muridnya sendiri, dari tujuh bulan menjadi tiga tahun. Perkara ini diputuskan oleh PN Tanjungbalai, tetapi diubah oleh Pengadilan Tinggi Sumut. Ketika mengadili seorang tokoh BTI/PKI, Mei 1965, Bismar berani melawan tekanan PKI. Sebab Bismar beranggapan, hakim itu wakil Tuhan di dunia. Dia juga menggelisahkan kekurangan pemahaman dan penjabaran hukum oleh para penegak hukum. Bagi dia, hukum itu hanya sebagai sarana, tujuannya ialah keadilan. Kalau sarana itu menjadi penghambat, maka harus disingkirkan, asal mencapai keadilan. Demi keadilan, baginya, tidak ada alasan bagi hakim menyatakan belum ada undang-undangnya. Hakimlah undang-undangnya.

Dia juga menyesalkan hakim-hakim yang tidak mengerti ajaran agamanya. Sebab hakim memutuskan perkara dengan diawali kata demi keadilan berdasarkan Ketuhanan Yang Maha Esa. Berarti keadilan yang menjadi landasan, bukan hukum, apalagi kepastian hukum. Saya menemukan itu dalam ajaran Islam: Kalau engkau menegakkan hukum, sesuai ajaran Tuhan tegakkan dengan adil. Pengalamannya sebagai hakim, selalu memutuskan perkara dengan bijaksana, dengan mendengar hati nurani. Dalam KUHAP juga disebut dengan arif dan bijaksana. "Sehingga kalau ditanya bagaimana kearifan itu? Itu kita harus hadir dalam diri sendiri, tidak ada itu kuliah di fakultas hukum," ujar Bismar Siregar. 


\section{Polisi Hoegeng}

Mantan Kapolri dan penganjur pertama pemakaian helm bagi pengendara sepeda motor di Indonesia, ini dikenal bersih dari korupsi, kolusi dan nepotisme (KKN). Dia simbol keteladanan dan kejujuran Polri. Di tengah terjadinya krisis kepercayaan kepada Polri dan birokrasi, ia tampil sebagai seorang yang pantas dipercaya. Sampai-sampai ada guyonan di masyarakat bahwa hanya ada dua polisi yang tidak bisa disuap, yaitu Hoegeng dan polisi tidur. Ia memang seorang pejabat (polisi) yang senantiasa hidup jujur dan bersahaja. Ia pantas diteladani.

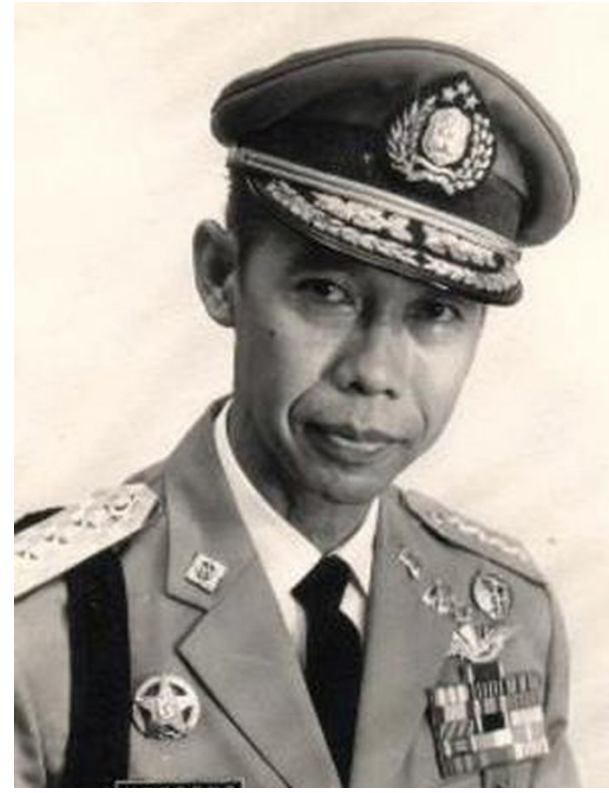

Gambar: Polisi Hoegeng Ia simbol kejujuran dan keteladanan bukan hanya bagi kepolisian dan seluruh jajaran birokrasi, tetapi juga bagi segenap lapisan masyarakat. Semasa menjabat Kepala Kepolisian Negara Republik Indonesia (Kapolri), dia pernah membongkar kasus penyelundupan mobil mewah. Dia pula orang pertama mencetuskan dan menganjurkan memakai helm bagi pengendara sepeda motor, serta menganjurkan kaki mengangkang bagi pembonceng sepeda motor. Ketika itu, dia banyak mendapat kritik. Walau kemudian, setelah ia pensiun, anjurannya berbuah dimana pengendara sepeda motor menjadi sadar betapa pentingnya memakai helm. Dia seorang yang jujur dan konsisten dalam melakukan kewajibannya sebagai polisi (kapolri). Namun ironisnya, akibat kejujuran dan keteguhannya melaksanakan tugas, dia malah diberhentikan dari jabatan Kapolri sebelum selesai masa jabatan yang seharusnya tiga tahun.

Tahun 1968 Presiden Soeharto mengangkat Hoegeng sebagai Kepala Polri menggantikan Soetjipto Yudodihardjo. Masa itu 


\section{HUKUM PROGRESIF}

kasus penyelundupan merajalela. Yang terkenal ialah kasus penyelundupan mobil mewah yang didalangi Robby Tjahyadi atau Sie Tjie It. Tahun 1969 penyelundupan tersebut dideteksi polisi. September 1971 Hoegeng mengumumkan kepada masyarakat tentang usahanya yang berhasil membekuk penyelundupan mobil mewah lewat Pelabuhan Tanjung Priok. Mobil-mobil itu dimasukkan dengan perlindungan tentara, dan dilaporkan Ibu Tien terlibat pula. Hoegeng bukannya diberi pujian, melainkan beberapa hari kemudian dia dipecat sebagai Kepala Polri. Sebelum itu Hoegeng mendapat tawaran untuk menjabat sebagai Duta Besar di Belgia melalui Menhankam Jenderal M Panggabean. Dalam buku yang ditulis Ramadhan $\mathrm{KH}$ diceritakan Hoegeng masih dipanggil Soeharto. "Lho bagaimana, Mas, mengenai soal Dubes itu?" tanya Soeharto. "Saya tak bersedia jadi dubes, Pak," jawab saya. "Tapi, tugas apa pun di Indonesia, akan saya terima." Presiden bilang, "Di Indonesia tak ada lagi lowongan, Mas Hoegeng." Maka saya pun langsung nyeletuk, "Kalau begitu, saya keluar saja." Mendengar itu ia diam. Saya juga diam. Mau ngomong apa lagi? Setelah kurang lebih setengah jam pertemuan, saya pun pamit, kata Hoegeng (disarikan dari berbagai Sumber).

Mereka; Baharudin Lopa, Bismar Siregar dan Hoegeng adalah tokoh-tokoh penegak hukum yang selalu merujuk pada hati nurani yang memiliki keberanian dalam menegakan hukum. Putusan hati nurani adalah nomor satu, sedangkan hukum adalah nomor dua. Sehingga ada ungkapan bahwa keadilan adalah di atas peraturan. Hukum bisa ditempatkan pada wilayah abu-abu. Masalah yang dihadapi adalah masalah sosial, kemasyarakatan dan kemanusiaan. Di lain pihak, ia dituntut untuk bekerja sebagai teknologi yang eksak. Tarikan antara titik kemanusiaan dan titik mesin inilah yang mewarnai dunia hukum saat ini. 


\section{Hukum Progresif}

Progresif berasal dari kata Progress yang berarti kemajuan. Hukum progresif berarti hendaknya hukum hendaknya mampu mengikuti perkembangan zaman, mampu menjawab perubahan zaman dengan segala dasar di dalamnya, serta mampu melayani masyarakat dengan menyandarkan pada aspek moralitas dari sumber daya manusia penegak hukum sendiri.

Kekuatan hukum progresif adalah kekuatan yang menolak dan ingin mematahkan keadaan status quo. Mempertahankan status quo adalah menerima normativitas dan sistem yang ada tanpa ada usaha untuk melihat aneka kelemahan dan berusaha untuk memperbaikinya. Hukum sangat rentan dengan terhadap keadaan status quo. Bagi para penegak hukum, mempertahankan status quo lebih mudah dan aman daripada berinisiatif melakukan perubahan dan pembaharuan. Kekuatan hukum progresif (kejaksaan, pengadilan, kepolisian, advokad, akademisi, LSM, birokrasi, dan pelaku ekonomi) akan mencari berbagai cara guna mematahkan kekuatan status quo. Hal ini merupakan paradigma aksi, bukan peraturan. Dengan demikian peraturan dan sistem bukan satu-satunya yang menentukan, yang paling penting adalah manusia yang bisa menolong kondisi buruk yang diakibatkan oleh sistem. Sehingga sangat diperlukan sikap kritis terhadap hukum normatif dan inilah semangat progresif untuk memberikan keadilan kepada rakyat (bringing justice to the people). Hakim-hakim progresif bertindak atas dasar itu.

Progresivisme membutuhkan dukungan pencerahan pemikiran hukum dan itu bisa dilakukan oleh komunitas akademi yang progresif. Kekuatan hukum progresif tidak sama sekali menepis kehadiran hukum positif, tetapi selalu gelisah menanyakan "apa yang bisa saya lakukan dengan hukum ini untuk memberi keadilan kepada rakyat?" Artinya, hukum tidak menjadi tawanan sistem dan undang-undang semata. Keadilan dan kebahagiaan rakyat ada di atas hukum. Progresivisme bertolak dari pandangan 


\section{HUKUM PROGRESIF}

kemanusiaan, manusia pada dasarnya baik, memilki sifat-sifat kasih sayang serta kepedulian terhadap sesama. Artinya hukum itu menjadi alat untuk menjabarkan dasar kemanusiaan tersebut. Hukum bukan raja, tetapi hanya alat saja yang memberikan rahmat kepada dunia dan manusia. Progresivisme tidak ingin menjadikan hukum sebagai teknologi yang tidak bernurani, melainkan suatu institusi yang bermoral kemanusiaan. Hukum mempunyai tujuan besar untuk kesejahteraan dan kebahagiaan manusia, maka hukum selalu berada pada status law in the making. Hukum bukan untuk dirinya sendiri dan tidak final. Artinya setiap putusan adalah sebagai terminal menuju kepada keputusan berikutnya yang lebih baik. Sehingga hukum ini selalu peka terhadap perubahan-perubahan yang terjadi dalam masyarakat. Misalnya; awalnya ada dua sistem hukum di dunia yang bekerja dengan jalannya masing-masing, yakni civil law dan common law. Civil law adalah sebuah sistem yang mencerminkan karya manusia yang sadar dan sengaja, sedangkan yang common law adalah sistem yang berkembang secara tradisional tanpa aktor-aktor pembuat yang nyata. Akan tetapi sekarang dunia berbicara mengenai keduanya pada suatu sistem yang mixed system. Tentunya percampuran itu terjadi karena berbagi faktor; fenomena global yang memicu kepadatan dan intensitas interasi, interface dan interchange kelembagaan dan proses-proses di dunia.

Hukum progresif dimulai dari asumsi dasar bahwa hukum adalah untuk manusia, bukan sebaliknya. Hukum progresif tidak menerima hukum sebagai institusi yang mutlak serta final, melainkan sangat ditentukan oleh kemampuannya untuk mengabdi kepada manusia. Hukum ini merupakan koreksi terhadap kelemahan sistem hukum modern yang syarat dengan birokrasi serta ingin membebaskan diri dari dominasi suatu tipe hukum liberal. Hukum progresif menolak pendapat bahwa ketertiban (order) hanya bekerja melalui institusi-institusi kenegaraan. Hukum ini ditujukan untuk melindungi rakyat 
menuju kepada ideal hukum dan menolak status quo, serta tidak ingin menjadikan hukum sebagai teknologi yang tidak bernurani, melainkan suatu institusi yang bermoral. Konsep pemikiran tersebut ditawarkan untuk diimplementasikan dalam tataran agenda akademis dan aksi. Agenda akademis, dalam arti hukum progresif menolak pengutamaan dan pengunggulan ilmu hukum yang bekerja secara analitis (analytical jurisprudence), yaitu mengedepankan peraturan dan logika. Hukum progresif lebih bertumpu pada aras sosilogis dalam menjalankan hukum.

Hukum adalah institusi yang bertujuan mengantarkan manusia kepada kehidupan yang adil, sejahtera dan membuat manusia bahagia. Secara lebih spesifik, hukum progresif adalah hukum yang pro rakyat dan hukum yang pro keadilan. Dalam konsep hukum progresif, hukum tidak ada untuk kepentingannya sendiri, melainkan untuk suatu tujuan yang berada di luar dirinya. Hukum ini ingin secara sadar menempatkan kehadirannya dalam hubungan erat dengan manusia dan masyarakat yang memiliki tipe responsif; artinya hukum akan selalu dikaitakan dengan tujuan-tujuan di luar narasi tekstual hukum itu sendiri.

Hukum progresif banyak dipengaruhi oleh aliran legal realisme yang melihat hukum bukan dari kacamata hukum itu sendiri, melainkan dilihat dan dinilai dari tujuan sosial yang ingin dicapainya serta akibat-akibat yang timbul dari bekerjanya hukum. Dalam aliran realisme, pemahaman orang tentang hukum melampaui peraturan dan teks dokumen. Karena kehadiran hukum dikaitkan dengan tujuan sosialnya, maka hukum ini juga dekat dengan sociological jurisprodence, Roscoe Pound. Studi hukum bukan hanya tentang peraturanperaturan, melainkan keluar dari situ dan melihat efek hukum serta bekerjanya hukum. Kedekatan hukum progresif dengan teori hukum alam terletak pada kepeduliannnya terhdap halhal yang oleh Hans Kelsen disebut sebagai meta juridical. Teori hukum alam mengutamakan the search for justice. Hukum 


\section{HUKUM PROGRESIF}

progresif mendahulukan kepentingan manusia yang lebih besar daripada menafsirkan hukum dari sudut logika dan peraturan. Hukum progresif juga memiliki kedekatan dengan Critical Legal Studies (CLS) di AS, tahun 1977. Keduanya muncul karena ketidakpuasan terhadap penyelenggaraan hukum di negera tersebut. 
BAB V

Penegakan Hukum (Law Enforcement) 
A pa yang dapat kita pahami dari pembahasan tentang beberapa

Aundang-undang yang sebelumnya sudah kita bahas; UU PKDRT, Korupsi, Agraria, Lingkungan, Politik? Apa yang tercantum indah dalam pasal-pasal tersebut belum bisa menjadi seindah apa yang terjadi di masyarakat. Harapan praktek kehidupan masyarakat sesuai dengan undang-undang masih jauh dari harapan pembuat undangundang itu sendiri. Diatas kertas indah dan harmoni, akan tetapi masyarakat kita masih dilekati kebudayaan dan watak yang tidak mudah untuk ditaklukan hanya dengan undang-undang. Mengingat hal tersebut adalah karakter,watak dan mental masyarakat. Walaupun demikian tidaklah tabu kita membicaraka tentang pengakan hukum di Indonesia untuk mengetahui dimanakah posisi kita sebagai negara hukum dan untuk memperbaiki kehidupan berhukum dalam hidup bermasyarakat dan bernegara.

\section{Pengertian Penegakan Hukum}

Penegakan hukum mempunyai dua arti, yakni;

\section{Arti Formil}

Menurut pemahaman ini, penegakan hukum diartikan sebagai upaya untuk menjaga keamanan dan ketertiban di masyarakat. Ketertiban masyarakat menjadi syarat utama lancarnya pembangunan, stabilitas keamanan masyarakat serta langgengnya kekuasaan status quo yang dominan pada situasi itu. Kondisi masyarakat diharapkan bisa diorganisir 
oleh kekuasaan publik, sistem kaidah-kaidah didasarkan pada hierakhi perintah dan tentunya penegakan hukum ini menjadi alat yang efektif untuk menjalankankan pemerintahan yang tiranis.

\section{Arti Materiil}

Dalam arti ini, penegakan hukum dikembalikan kepada hakikat dan fungsi hukum yang sesungguhnya yakni adanya jaminan keadilan sosial (keadilan setiap golongan mendapatkan penghargaan dan tidak dirugikan oleh pihak atu golongan lain). Hukum justru menjadi pelindung bagi masyarakat dari kekuasaan yang semena-mena dan menindas.

Penegakan hukum merupakan rangkaian proses untuk menjabarkan nilai, ide,cita yang abstrak yang menjadi tujuan hukum. Tujuan hukum atau cita hukum memuat nilai-nilai moral (keadilan dan kebenaran) yang harus diwujudkan dalam kehidupan nyata. Menurut Soerjono Soekanto, penegakan hukum adalah kegiatan menyerasikan hubungan nilai-nilai yang terjabarkan di dalam kadiah-kaidah yang mantap dan mengejawantah sikap tindak sebagai rangkaian penjabaran nilai tahap akhir untuk menciptakan, memelihara dan mempertahankan kedamaian pergaulan hidup. Sementara itu penegakan hukum progresif adalah menjalankan hukum tidak sekedar menurut kata-kata hitam putih dari peraturan (according to the letter), melainkan menurut semangat dan makna lebih dalam (to the very meaning) dari undang-undang atau hukum dan penegakan hukum ini dilakukan dengan kecerdasan spiritual bukan hanya inteletual saja. Konsep pemikiran dalam penegakan hukum dimulai pada saat peraturan hukumnya dibuat atau diciptakan. Penegakan hukum adalah suatu proses untuk mewujudkan cita-cita hukum menjadi kenyataan. Keinginan-keinginan hukum adalah pikiran-pikiran badan pembuat undang-undang yang dirumuskan dalam peraturan-peraturan hukum. Yang dapat digambarkan sebagai berikut: 


\section{Bagan.2 Tujuan Hukum}

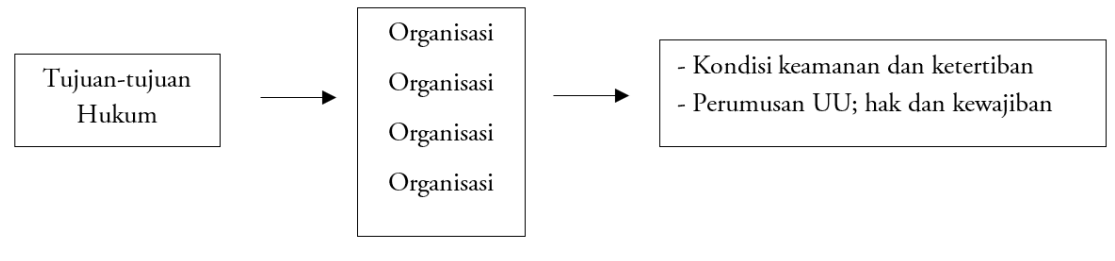

Sumber: Satjipto, 2009

Artinya bahwa untuk menerjemahkan tujuan-tujuan hukum menjadi perumusan UU atau untuk mewuju7dkan kondisi keamanan dan ketertiban di masyarakat diperlukan perangkat organisasiorganiasasi yang komplek. Organisasi tersebut lahir sebagai wujud dari adanya masyarakat yang kompleks untuk mengakomodir beranekaragamnya kondisi sosial, ekonomi dan politik. Organisasi yang dimaksud adalah pembuat hukum dan birokrasi penegak hukum.

\section{Alur Penegakan Hukum}

Unsur-unsur yang terlibat dalam penegakan hukum dibagi menjadi 2; unsur-unsur yang mempunyai tingkat keterlibatan yang jauh (lingkungan pribadi ataupun sosial) dan dekat (badan legislatif dan kepolisian). Proses penegakan hukum menjangkau sampai pula pada pembuatan hukum. Perumusan pikiran pembuat hukum yang dituangkan dalam peraturan hukum akan turut menentukan bagaimana penegakan hukum itu dijalankan. Pada kenyataannya proses penegakan hukum memuncak pada pelaksanaannya oleh para pejabat penegak hukum. Sementara itu, tingkah laku orang dalam masyarakat didisiplinkan oleh kaidah-kaidah yang terdapat dalam masyarakat. Kaidah-kaidah tersebut mengikat dan membatasi tingkah laku orang-orang dalam masyarakat, termasuk didalamnya para pejabat hukum. Hubungan tersebut dapat diliat dalam bagan berikut ini; 


\section{Bagan.3 Alur Penegakan Hukum}

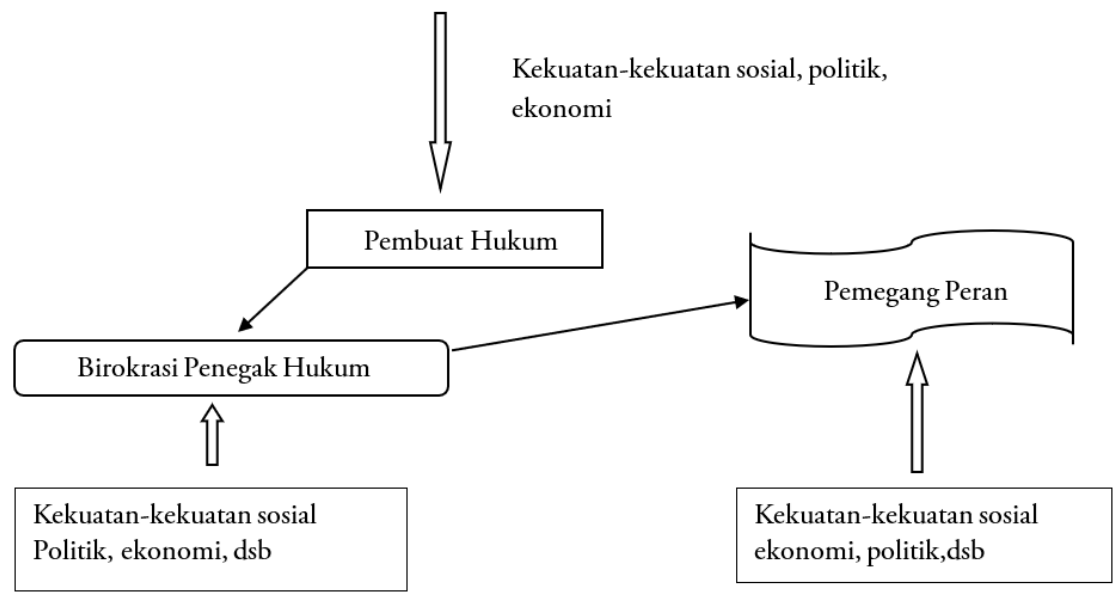

Sumber: Satjipto, 2009

\section{Penegakan Hukum dan Struktur Masyarakat}

Penegakan hukum bukanlah sutau kegiatan yang berdiri sendiri, melainkan mempunyai hubungan timbal balik yang erat dengan masyarakat. Hukum yang dimaksud itu adalah hukum modern yang mengiringi lahirnya masyarakat modern. Dalam tahap perkembangan masyarakat ditinjau dari perkembangan hukum, menurut Gianfranco Poggi proses pembentukannya dibagi dalam tahap-tahap sebagai berikut;

1. Feodalisme

(belum ada hukum tertulis, sengketa diselesaikan dengan kekeluargaan dan komunal )

2. Standestaat te

(awal adanya tata kehidupan hukum dan kenegaraan, mulai adanya kelompok atau individu yang mengatur masyarakat)

3. Absolutisme

(kekuasaan ditentukan oleh penguasa)

4. Masyarakat perdata 
(lahirnya penyeimbang penguasa dalam bentuk penguatan civil society dan korporasi)

5. Negara Konstitusional

(adanya peraturan yang diberlakukan oleh aparat negara kepada masyarakatnya)

Berdasarkan tahap-tahap perkembangan masyarakat tersebut, menurut Weber semakin maju masyarakat, maka pola pikirnya semakin rasional yang bertumpu pada kepercayaan terhadap kesahihan pola-pola kaidah normatif dan terhadap hak mereka dari mereka yang memiliki otoritas yang muncul dari akidah tersebut. Penggarapan hukum dilakukan secara sistematis dan penyelenggaraan hukum secara sistem dan penyelenggaraan hukum yang dijalankan secara profesional dengan cara ilmiah dan logis formal. Kondisi puncaknya adalah terbentuknya negara konstitusional. Sebelum terbentuk negara konstitusional penyelesaian masalah dalam masyarakat diselesaikan sebagai berikut:

Tabel.3 Penyelesaian Masalah dalam Masyarakat

\begin{tabular}{|l|l|l|}
\hline & $\begin{array}{l}\text { Masyarakat } \\
\text { Yang kurang komplek }\end{array}$ & $\begin{array}{l}\text { Masyarakat } \\
\text { lebih kompleks }\end{array}$ \\
\hline \multirow{2}{*}{$\begin{array}{l}\text { Masyarakat } \\
\text { Yang kurang berlapis }\end{array}$} & perukunan & penerapan hukum \\
\cline { 2 - 3 } & perukunan & perukunan \\
\hline $\begin{array}{l}\text { Masyarakat } \\
\text { Yang lebih berlapis }\end{array}$ & perukunan & penerapan hukum \\
\cline { 2 - 3 } & penerapan hukum & penerapan hukum \\
\hline
\end{tabular}

Sumber: Satjipto, 2009

Rasionalitas menjadi sangat dominan diterapkan di Negara konstitusional. Persoalan masyarakat yang kompleks dan posisi masyarakat yang berlapis menyebabkan perlunya diterakan hukum untuk mengatur organisasi yang ada di masyarakat. 


\section{Penegakan Hukum di Indonesia}

Lantas bagaimanakah penegakan hukum di Indonesia? Dalam kehidupan bernegara kita mengakui bahwa Negara berdasarkan hukum dan tidak berdasarkan pada kekuasaan belaka, Pemerintah berdasarkan konstitusi bukan pada kekuasaan belaka (Rule of law dilakukan oleh kekuasaan yudikatif) dan kekuasaan kehakiman dilakukan oleh Mahkamah Agung, sebagai pemegang kekuasaan yang merdeka. Berdasarkan tahap perkembangan masyarakat berdasarkan hukum (menurut Goff) kita merupakan negara konstituisonal. Artinya bahwa setiap relasi yang berhubungan dengan orang lain di masyarakat diatur dengan hukum sebagai panglima tertinggi, tidak hanya kekeluargaan apalagi komunal.

Akan tetapi apabila kita kaji lebih jauh karakter masyarakat kita masih menunjukkan watak dan sisa-sisa masyarakat Feodal. Hal ini nampak dalam budaya, misalnya tidak adanya kesetaraan antara lakilaki dan perempuan di masyarakat. Pembagian kerja domestik dan publik masih sangat kentara antara laki-laki dan perempuan. Adanya UU PKDRT pun ternyata belum mampu memecahkan problem kesetaraan tersebut. Selalu saja ada kasus kekerasan yang dilakukan berdasarkan jenis kelamin. Dalam relasi politik, relasi patron klien masih mengakar pada deciton maker untuk membuat keputusan publik. Demikian halnya peta perpolitikan di masyarakat kita juga diwarnai oleh hubungan KKN yang sangat kental. Tentunya ini menyebabkan kompetisi yang tidak sehat di dalam masyarakat dan menghambat tumbuhnya demokrasi dan penegakan hukum. Kondisi ini menunjukan bahwa ada dunia yang berbeda akan tetapi berjalan dalam satu rel, kehidupan hukum yang bersifat rasional diterapkan dalam masyarakat yang masih bersifat komunal.

Dampaknya yang dapat kita amati adalah penegakan hukum yang ada di negara kita cenderung bersifat formil semata, yakni untuk melanggengkan kekuasaan penguasa. Bukan pada arti materilnya, penegakan hukum untuk menegakan hukum itu sendiri (keadilan, 
kepastian hukum dan kemanfaatan) bagi masyarakat secara adil, tanpa ada diskriminasi. Jadi sangat lumrah beberapa kasus di dunia hukum kita tidak berpihak kepada orang miskin, hukum lebih peka terhadap masyarakat pada kelas-kelas tertentu. Gejala yang nampak juga adalah apa yang dikatakan Myrdal sebagai sweeping legislation, yakni pembuatan perundang-undangan secara terburuburu tanpa melakukan penelitian, dengar pendapat secara serius dengan masyarakat. Akibatnya lahir banyak undang-undang yang justru tidak ditaati oleh masyarakat. Bahkan masyarakat sendiri tidak mengathui kalau tindakannya diatur oleh aturan hukum. $\left({ }^{*}\right)$ 
BAB VI

Sosiologi

Hukum Islam 
Dengertian Sosiologi Islam sangat perlu untuk dikaji berkaitan 1 dengan sosiologi dan Islam sebagai ilmu.

\section{Pengertian Syari'ah dan Fiqh}

Syari'ah secara etimologis berarti jalan tempat keluarnya air untuk minum. Kata ini kemudian dikonotasikan oleh Bangsa Arab dengan jalan lurus yang harus diturut. Secara terminologis (istilah) syari'ah menurut Syaikh Mahmud Syaltut, mengandung arti hukum-hukum dan tata aturan yang Allah Syariatkan begi hamba-hambaNya. Menurut Manna al Qathan, syariah berarti segala ketentuan Allah yang disyariatkan bagi hamba-hambanya, baik menyangkut akidah, ibadah akhlak dan muammalah. Berdasarkan kesimpulan diatas, syariah itu sama dengan agama. Dalam perkembangan selanjutnya, kata Syariah tertuju atau digunakan untuk menunjukan hukumhukum Islam, baik yang ditetapkan oleh Al Qur'an dan Sunnah, maupun yang telah dicampuri oleh manusia (Djamil, 1987).

Fiqh secara semantik bermakna untuk mengetahui sesuatu dan memahaminya dengan baik. Sedangkan secara terminologis, menurut Abu Zahrah mengetahui hukum-hukum syara' yang bersifat amaliyah yang dikaji dari dalil-dalil yang terperinci. Berdasarkan pengertian tersebut, fiqh bukanlah hukum syara' itu sendiri, tetapi interpretasi terhadap hukum syara'. Mengingat fiqh itu hanya interpretasi yang bersifat zanni yang terikat dengan situasi dan kondisi yang melingkupinya, maka fiqh senantiasa berubah seiring dengan perubahan waktu dan tempat. Berdasarkan pengertian 
tersebut, hakikat fiqh dapat dipahami, yaitu;

1. Fiqh adalah ilmu tentang hukum syara'

2. Fiqh membicarakan hal-hal yang bersifat 'amaliyyah furu'iyyah (praktis dan bersifat cabang)

3. Pengetahuan tentang hukum syara' didasarkan pada dalil tafsili, yakni Al Qur'an dan Hadis

4. Fiqh digali dan ditemukan melalui penalaran dan istidlal mujtahid (Djamil, 1987)

Syariah sebagai hukum Allah diturunkan di muka bumi dengan tujuan menegakan kemaslahan, kedamaian dan kebahagiaan umat manusia. Syariah ada yang diterangkan secara jelas dan ada yang samar (implisit). Terhadap hukum yang bersifat implisit ini, perlu dilakukan pengkajian dan penelitian terhadapnya. Ketentuan yang terperinci tentang tingkah laku mukallaf diramu dan diformulasikan sebagai hasil pemahaman terhadap syariah. Hasil pemahaman tersebut yang disebut fiqh. Sehingga secara sederhana fiqh tersebut diartikan sebagai penjelasan terhadap syariah yang terang dan agak terang serta pemahaman dan penggalian terhadap kandungan syariah yang tidak tampak (Djamil, 1987).

\section{Pengertian Hukum Islam}

Kata hukum Islam sama sekali tidak ditemukan dalam Al Qur'an dan literatur hukum dalam Islam. Yang ada dalam Al Qur'an dalah kata-kata Syariah, fiqh, hukum Allah dan yang seakar dengannya. Kata-kata hukum Islam merupakan terjemahan dari term Islamic law dari literatur Barat. Apabila hukum dihubungkan dengan Islam, maka hukum Islam berarti seperangkat peraturan berdasarkan wahyu Allah dan Sunnah Rasul tentang tingkah laku manusia mukallaf yang diakui dan diyakini berlaku dan mengikat untuk semua umat yang beragam Islam (Djamil, 1987).

Hukum Islam mengacu pada pandangan hukum yang bersifat teleologis, artinya hukum Islam itu diciptakan karena ia mempunyai maksud dan tujaun. Tujuan dari adanya hukum Islam adalah 
terciptanya kedamaian di dunai dan akhirat. Bukan kebahagiaan yang fana dan di dunia semata, tetapi juga di akhirat kelak. Tujuan dari hukum Islam tersebut merupakan manifestasi dari sifat Rahman dan Rahim. Dengan adanya syari'ah tersebut dapat ditegakan di muka bumi dengan pengaturan masyarakat yang memberikan keadilan kepada semua orang (Djamil, 1987).

Hukum Islam adalah hukum yang dibangun berdasarkan pemahaman manusia atas nash $\mathrm{Al}$ Qur'an maupun As sunnah untuk mengatur kehidupan manusia yang berlaku universal, relevan pada setiap ruang dan waktu manusia. Keuniversalan hukum Islam ini sebagai kelanjutan dari hakikat Islam sebagai agama Universal, yakni agama yang substansi-substansi ajaranNya tidak dibatasi oleh ruang dan waktu manusia, melainkan berlaku bagi semua orang Islam dimanapun dan kapanpun. Hukum Islam merupakan istilah khas Indonesia sebagai terjemahan dari al fiqh al Islami atau dalam konteks tertentu disebut al syariah al islami, atau dalam literatur Barat disebut dengan Islamic Law. Wahyu Allah dalam al Qur'an menjadi memuat hukum Islam yang utama. Kata syariah kemudian dijelaskan oleh Rasulullah dengan ijtihad-ijtihadnya yang berwujud dalam Al Sunnah. Adapun Al Fiqh adalah proses pemahaman terhadap al syariah yang tidak terlepas dari situasi dan kondisi sosial masyarakat. Al Qur'an sebagai sumber pertama hukum Islam, di dalamnya memuat ajaran-ajaran di bidang hukum perdata, dagang, pidana, Tata Negara, acara, perburuhan, ekonomi dan sosial dan hukum Internasional. Ketentuan-ketentuan hukum yang termuat dalam Al qur'an dilengkapi dengan sunnah Rasul dan dikembangkan dengan ijtihad Ulama, keputusan Pemerintah dan ijtihad hakim dalam yurisprudensi (Al Munawar, 2004).

Mulai dari awal kedatangan Islam sampai dengan saat ini, hukum Islam menjadi faktor penting dalam menentukan setiap pertimbangan politik untuk mengambil kebijakan dalam penyelenggaraan Negara. Mengenai sejarah berlakunya hukum Islam di Indonesia, dapat dilihat dari dua periode yakni: 1) periode penerimaan hukum Islam 
sepenuhnya dan 2) periode penerimaan hukum Islam oleh hukum adat. Periode penerimaan hukum Islam oleh hukum adat, disebut sebagi teori receptive. Penerimaan hukum Islam sepenuhnya disebut dengan teori receptio in complexu. Pada masa ini hukum Islam dilaksanakan sepenuhnya oleh hukum Islam, semenjak adanya kerajaan-kerajaan Islam di Indonesia, pemerintah hukum kolonial juga memberlakukan hukum Islam bagi umat Islam, khususnya hukum perkawinan dan hukum waris yang kemudian disebut dengan hukum kekeluargaan.

\section{Hukum Islam Pada Zaman Belanda}

VOC yang lebih dahulu berkuasa di Indonesia tidak terlalu memperdulikan agama dan kebudayaan yang ada di Indonesia. Setelah kekuasaan VOC diambil alih oleh Pemerintah Kerajaan Belanda, baru ada perhatian terhadap perkembangan Islam di Indonesia, terutama karena gerakan Pan Islamisme yang berpusat di Turki semasa kekuasaan Kesultanan Uthmaniyyah di Istambul, merupakan Imperium Islam di eropa Timur dan Asia kecil pada abad ke XVII sampai abad ke XX. Pan Islamisme ini bertujuan untuk mempersatukan umat Islam sedunia dengan Sultan Turki sebagai pimpinan tertinggi. Belanda mendapat perlawanan dari kesultanan dan pemimpin umat Islam di seluruh Indonesia, sepanjang abad ke XIX. Oleh karena itu Belanda memperhatikan psychology massa antara lain dengan membiarkan berlakunya hukum Islam di Indonesia. Pengakuan tersebut akhirnya dituangkan dalam peraturan-peraturan hukum seperti terdapat dalam pasal 11 Algemene Bepalingen van Wetgeving disingkat A.B. jo Pasal 131 ayat 2 Indische Staatsregeling atau I.S. Pada pokoknya pasal 11 A.B menentukan bahwa bagi orang Indonesia yang baginya berlaku Hukum Perdata Belanda baik karena agama, penaklukan sukarela pada hukum perdata Barat, baginya berlaku ketentuan-ketentuan hukum Indonesia, yakni hukum agama, lembaga-lembaga dan kebijakan-kebijakan sepanjang tidak bertentangan dengan asas keadilan. Mengenai kegiatan keagamaan 
terlihat adanya sikap diskriminatif terhadap agama-agama selain Kristen, termasuk Islam (Syahar, 1986). Pelaksanaan hukum Belanda dikeluarkan peraturan Resolutie der Indische Regeering tanggal 25 Mei 1760, yang kemudian dikenal dengan Compendium Freijer. Dalam Reggerings Reglement (RR) tahun 1885, pasal 75 dinyatakan bahwa oleh hakim Indonesia, hendaklah diberlakukan undang-undang agama (Godsdienstige Wetten) (Al Munawar, 2004).

\section{Hukum Islam dan Hukum Adat}

Adapun periode penerimaan hukum Islam oleh hukum adat, dipahami bahwa hukum Islam berlaku bila dikehendaki atau diterima oleh hukum adat. Bila yang dimaksud hukum adat adalah kebiasaan maka pertengahan abad ke-19 hukum agama dalam hal ini hukum Islam dan hukum kebiasaan berlaku sama kuat sepanjang dihormati oleh masyarakat dan selama tidak bertentangan dengan kepentingan umum dan merupakan kebutuhan kemasyarakatan yang nyata. Istilah hukum adat baru dikenal pada abad ke-19 oleh Van Vollenhoven. Menurutnya bagi golongan bumiputera, hukum yang berlaku baginya adalah hukum adat, yakni hukum yang turun menurun (tradisional) Indonesia. Hukum agama termasuk dan terutama hukum Islam merupakan tambahan atau pelengkap hukum tradisional yang telah ada di masyarakat. Pendapat ini berdasarkan pada banyaknya pengurangan kekuasaan raja-raja dan sultan-sultan Islam di Indonesia oleh Belanda (Syahar, 1986).

Sementara menurut Mr. Van den Berg yang menganggap bahwa hukum kebiasaan atau hukum adat adalah hukum agama, bila masyarakat setempat beragama Islam, maka hukum yang berlaku (hukum adatnya) adalah hukum Islam. Demikian halnya apabila masyarakat setempat juga beragama lain, maka hukum yang adat yang berlaku adalah hukum agama itu sendiri. Teori ini yang dikenal dengan receptio in complex. Pendapat van den Berg ini berdasarkan pada zaman sebelum pemerintah Belanda mengeliminir kekuasaan sultan-sultan dan raja-raja Islam di Indonesia (Syahar, 1986). 
Pada Zaman kemerdekaan, hukum Islam pun melewati dua kali periode; 1) periode penerimaan hukum Islam sebagai sumber persuasive. 2) Periode kedua adalah periode hukum Islam sebagai autoritatif. Sumber persuasif dalam konteks hukum konstitusi, yaitu sumber hukum yang baru diterima apabila diyakini. Dalam hukum Islam, piagam Jakarta sebagai salah satu hasil sidang BPUPKI merupakan sumber persuasif. Hukum Islam baru menjadi autoritatif (sumber hukum yang telah mempunyai kekuatan hukum) dalam ketatanegaraan, ketika dekrit Presiden 5 Juli yang mengakui bahwa Piagam Jakarta menjiwai UUD 1945 (Al Munawar, 2004).

\section{Materi Hukum Islam Secara Nasional}

Apabila dilihat dari ilmu Fiqh, maka yang dapat dimasukan ke dalam hukum Islam itu adalah bagian dari mu'amalat dari Syariat, sementara ibadah yang merupakan relasi antara manusia dengan Tuhan tidak menjadi bagian dari hukum positif Indonesia. Hal tersebut menunjukan adanya perubahan yang menandai perkembangan hukum Islam dan masyarakat muslim. Perubahan tersebut pada orientasi masyarakat Muslim dari urusan ibadah (hubungan vertikal manusia dengan Allah) kepada urusan muammalat (hubungan horizontal manusia dengan lingkungan alam). Mu'amalat itu menurut kitab-kitab fiqh meliputi;

1. Munakahat dengan syarat dan rukunnya

2. Faraidh atau pembagain warisan

3. Jinayat atau hukum pidana

4. Jihad atau hukum perang

5. Buyu' atau jual-beli termasuk riba

6. Syarikat atau perseorangan

7. Al suthanat atau hukum tata Negara

8. Aqdhiyah atau hukum acara

Diantara materi hukum islam (mu'amalat) diatas yang telah masuk sebagai hukum Indonesia hanyalah bagian munakahat untuk seluruh Indonesia dan faraidh untuk sebagian Indonesia 


\section{SOSIOLOGI HUKUM ISLAM}

(Syahar,1986). Kontribusi materi hukum Islam tersebut dapat kita lihat pada beberapa undang-undang sebagai berikut;

1. UU No.1/1974 tentang perkawinan

2. UU No.2 tahun 1989 tentang Sistem Pendidikan Nasional

3. UU No.7/1989 tentang Peradilan Agama

4. Kompilasi Hukum Islam (KHI)

5. PP No. 28 tahun 1991 tentang Perwakafan nasional

6. UU No. 38 tahun 1999 tentang Pengelolaan zakat.

Sejarah perjalanan hukum Islam di Indonesia, kehadiran hukum Islam dalam hukum nasional merupakan perjuangan eksistensi merumuskan keadaan hukum nasional Indonesia, masa lalu, masa kini dan masa datang menegaskan bahwa hukum Islam itu ada dalam hukum nasional, baik secara tertulis atau pun tidak tertulis. Ia ada dalam berbagai lapangan kehidupan hukum dan praktek hukum. Teori eksistensi dalam kaitannya dengan hukum Islam adalah teori yang menerangkan tentang adanya hukum Islam dalam hukum nasional Indonesia, ada dalam arti;

1. Bagian integral dari dari hukum nasional Indonesia

2. Kemandirian yang diakui

3. Hukum nasional dan norma hukum Islam yang berfungsi sebagai penyaring bahan-bahan hukum nasional

4. Bahan utama dan unsur utama

Jadi secara eksistensial kedudukan hukum Islam dalam hukum nasional merupakan sub sistem dari hukum nasional. Karenanya hukum Islam juga menjadi memberikan sumbangan bagi pembaharuan dan pembentukan hukum nasional. Bagaimana secara sosiologis, tentunya pada kondisi eksistensial tersebut, hukum Islam melibatkan kesadaran keberagaman dalam masyarakat, penduduk yang sedikit banyak berkaitan dengan masalah kesadaran hukum dan norma hukum.

Disamping itu, penerapan hukum Islam di Indonesia perlu memperhatikan yakni;

1. Kemajemukan bangsa (pluralisme dan multikulturalisme) 
2. Metode pendidikan hukum yang cenderung bersifat trikotomi; Islam, barat dan adat

3. Kurangnya pengkajian akademik di bidang hukum Islam (Al munawar, 2004)

\section{Sosiologi Hukum Islam}

Menurut Soerjono Soekanto sosiologi hukum adalah suatu cabang ilmu pengetahuan yang secara analitis dan empiris mempelajari hubungan timbal balik antara hukum dengan gejala-gejala sosial lainnya. Maksudnya sejauh mana hukum itu mempengaruhi tingkah laku sosial dan pengaruh tingkah laku sosial terhadap pembentukan hukum (Tebba, 2003). Dengan obyek sosiologi hukum adalah; produk undang-undang, para pejabat hukum dan pendapat para ahli tentang situasi dan kondisi hukum yang berada di dalam masyarakat.

Hukum Islam tidak saja berfungsi sebagai hukum secular, tetapi juga berfungsi sebagai nilai-nilai normatif. Ia secara teoritis berkaitan dengan segenap aspek kehidupan dan satu-satunya pranata (institusi) sosial dalam Islam yang dapat memberikan legitimasi terhadap perubahan-perubahan yang dikehendaki dalam penyelarasan antara Islam dan dinamika sosial. Sehingga hukum Islam mempunyai fungsi ganda; 1) sebagai hukum berusaha mengatur tingkah laku manusia (umat Islam) sesuai dengan citra Islam dan 2) sebagai norma memberikan legitimasi ataupun larangan-larangan tertentu dengan konteks spiritual. Apabila dilihat dari segi hukum tidak bisa lepas dari pengaruh lingkungan sosial dan budaya di sekitarnya dan dari norma menunjukan bahwa adanya intervensi Allah dalam penetapan hukum. Hal itu yang menjadi ciri dari hukum Islam dan yang membedakan masyarakat Islam dengan di luar Islam. Pola cita masyarakat bukan Islam terbentuk berdasarkan pengalaman dan pemikiran sosial secara evolusi, sedangkan pola cita masyarakat Islam diturunkan oleh Allah berupa wahyu dan terbentuk secara revolusi (cepat). (Tebba, 2003). 


\section{Catatan:}

Berlakunya hukum Islam di Indonesia merupakan sub sistem dari hukum nasional. Artinya hukum Islam bukan menjadi acuan pokok, akan tetapi hukum Islam justru harus mengacu pada konstitusi dasar yang ada di Indonesia, Pancasila dan UUD 1945. Situasi ini ditunjang karena bangsa Indonesia sangat plural dan multikultur, dari segi sosial budaya dan termasuk religiusnya. Sehingga pemberlakuan hukum Islam tentunya perlu dikaji lebih jauh.

Mengkaji tentang pelaksanaan hukum Islam di Indoensia harus dilakukan karena di Negara ini, mayoritas penduduknya beragama muslim. Salah satu cara yang ditempuh adalah dengan melakukan penelitian untuk memahami secara mendalam tentang kasus-kasus yang terjadi dalam pelaksanaan hukum Islam. Umat Islam harus mampu menjabarkan hukum Islam dalam konteks sosiologis. Di sinilah pentingnya sosiologi hukum Islam. Adapun cabang-cabang hukum Islam yang dikenal selama ini adalah; tarikh tasyri' (sejarah hukum Islam), falsafah al tasyri' al Islami (filsafat hukum Islam), qawaid fiqh (kaidah-kaidah hukum Islam), ushul fiqh (pengantar hukum Islam) dan fiqh itu sendiri. Penjabaran dalam sosiologis itu perlu dilakukan agar pelaksanaan hukum Islam itu benar-benar memperhatikan keadilan semua umat dan Islam benar-benar menjadi rahmatan lil 'alamin. Kalaupun selama ini pembahasan hukum yang berkaitan dengan muammalat dikatakan sudah selangkah lebih maju apabila dibandingkan dengan pembahasan ibadah, maka ke depan hukum Islam harus lebih progressif lagi dengan konteks kehidupan sosial yang lebih kompleks atau melahirkan fiqh sosial. Pada kondisi seperti ini sosiologi hukum Islam sangat diperlukan untuk lebih membumikan hukum Islam. 
BAB VII

Definisi dan

Perkembangan

Kriminologi 


\section{Pengertian Kriminologi}

Faktor yang mendorong lahirnya kriminologi;

1. Ketidakpuasan terhadap hukum pidana, hukum acara pidana dan sistem penghukuman.

Hukuman pidana diterapkan semata-mata untuk menakutnakuti dengan jalan menjatuhkan sanksi yang berat—hukuman mati dengan tujuan masyarakat dapat terlindungi dari kejahatan. Napoleon dalam UUnya Code Civil Napoleon (1791); ada tiga prinsip UU;

a. Kepastian hukum-hukum tertulis

b. Persamaan hukum-menentang keberpihakan dalam hukum

c. Keseimbangan antara kejahatan dan hukuman

2. Penerapan metode statistic criminal (Topo Santoso, 7)

P. Topinard (1911) menyatakan bahwa kriminologi adalah ilmu tentang kejahatan atau penjahat, yang berasal dari;

Crimen yang berarti kejahatan atau penjahat dan Logos yang berarti ilmu pengetahuan. Kriminologi merupakan;

a. Studi tentang tingkah laku manusia, tidak berbeda dengan kajian lain yang bersifat non criminal

b. Ilmu yang bersifat inter dan multi disiplin, bukan mono disiplin

c. Berkembang sejalan dengan pengetahuan yang lain

d. Perkembangan studi kejahatan telah membedakan antara kejahatan sebagai tingkah laku dan pelaku kejahatan sebagai 
subyek perlakuan sarana peradilan pidana

e. Kriminologi telah menempatkan dirinya sejajar dengan ilmu pengetahuan yang lainnya, tidak lagi merupakan bagian daripadanya (Romli Atmasasmita, 2010)

Pengertian kriminologi yaitu:

a. Menurut W.A Boner, kriminologi adalah ilmu pengetahuan yang bertujuan menyelidiki gejala kejahatan seluas-luasnya

b. Menurut Edwin H. Sutherland dan Donald R. Cressy, kriminologi adalah suatu pengetahuan mengenai kejahatan sebagai gejala sosial, mengemukakan bahwa ruang lingkup kriminologi mencakup proses-proses pembuatan hukum, pelanggaran hukum dan reaksi atas pelanggaran hukum. Sehingga kriminologi dibagi menjadi 3 bagian utama;

1) Sosiologi hukum - mengkaji perkembangan hukum dari tinjauan sosiologis

2) Etiologi kehajatan — analisa ilmiah mengenai sebabsebab kejahatan

3) Penology — pengendalian kejahatan (hukuman)

W.H. Nagel menjelaskan kriminologi tidak hanya semata-mata etiologi kejahatan. Dalam masyarakat demokratis terdapat aturan atau peraturan yang diundangkan oleh golongan penguasa atau golongan dominan untuk mengatur perilaku anggotanya. Jika peraturan tersebut diundangkan oleh negara, maka pelanggaran terhadap hukum yang dilakukan oleh masyarakat tersebut yang disebut sebagai kejahatan. Berbagai pola pelanggaran, tanggapan pemerintah atau masyarakat atas pelanggaran-pelanggaran itu, akibat pelanggaran-pelanggaran itu atas perubahan sosial dalam masyarakat, identifikasi dan pembinaan pelanggar hukum yang merupakan aspek-aspek masalah kejahatan banyak dibahas dalam kriminologi.

Martin L. Haskell dan Lewis Yablonsky, kriminologi sebagai studi ilmiah tentang kejahatan dan penjahat yang mencakup analisa tentang; 
a. Sifat dan luas kejahatan

b. Sebab-sebab kejahatan

c. Perkembangan hukum pidana dan pelaksanaan peradilan pidana

d. Ciri-ciri penjahat

e. Pembinaan penjahat

f. Pola-pola kriminalitas dan

g. Akibat kejahatan atas perubahan sosial

Menurut G.P. Hoefnagels memberikan gambaran tentang ruang lingkup kriminologi secara luas, lihat Soerjono Soekanto. Bagan ini menunjukan rumusan kriminologi yang diperluas, yakni sebagai suatu ilmu pegetahuan empiris yang untuk sebagian dihubungkan dengan norma hukum, yakni mempelajari kejahatan serta prosesproses formal dan informal dari kriminalisasi dan dekriminalisasi, situasi kejahatan-penjahat dan masyarakat, sebab-sebab dan hubungan diantara sebab-sebab kejahatan, serta reaksi -reaski dan tanggapan-tanggapan resmi dan tidak resmi terhadap kejahatanpenjahat dan masyarakat (Soerjono Soekanto, 1976).

General Criminology atau kriminilogi umum menempati posisi sentral sebagai etiologi (pengetahuan mengenai sebab musabab) kejahatan dan kebijakan pidana dan didukung oleh satu pihak oleh bidang pengetahuan, bidang yang bertautan dan bidang penerapan. Dalam kerangka tersebut, disiplin adalah kerangka berpijak serta konsep-konsep yang digunakan untuk mempelajari kejahatan dan hukuman, untuk menghindari monocausal theories. Sehingga criminal jurism melengkapi dengan psikologi, psikiatri dan sosiologi dalam mempelajari pelanggaran hukum serta para pelanggar. Hukum pidana memberikan bantuan dalam menentukan luasnya bidang kejahatan sebagai bidang perilaku yang dapat dihukum (Soerjono Soekanto, 1976).

Roscoe Pound menggunakan istilah "the legal social science", yang menurut Hoefgels, sosiologi hukum pidana dan psikologi hukum pidana mempelajari; 
a. Interaksi antara norma-norma hukum dengan manusia dan masyarakat

b. Proses dan akibat yang menyangkut masalah kriminalisasi dan dekriminalisasi

c. Reaksi terhadap penjahat dan kejahatan

d. Mekanisme-mekanisme dalam bekerjanya sistem peradilan pidana

e. Enkulturasi petugas mengenai tugas-tugasnya

f. Gambaran sikap dan pembentukan peranan di antara pejabatpejabat serta alat-alat penegak hukum

g. Penghukuman, sebagai aspek sosio legal serta psiko legal dari penologi

h. Metode-metode penanganan kejahatan (Soerjono Soekanto, 1976)

Sosiologi kriminal merupakan bidang yang mempelajari pengaruh masyarakat terhadap kejahatan dan penjahat serta hubungan antara reaksi hukum pidana dan masyarakat.

Berdasarakan berbagai macam pendapat tersebut dapat disimpulkan bahwa kriminologi adalah ilmu yang meneliti kejahatan sebagai sebuah gejala sosial, sehingga ruang lingkupnya mencakup: Proses terjadinya hukum (pidana), penyimpangan terhadap hukum atau pelanggarannya dan reaksi terhadap pelanggaran-pelanggaran tersebut (Soerjono Soekanto, 1976, 25).

Manheim menyatakan bahwa kriminologi harus diperluas dengan memasukai 'conduct norm' (norma-norma kelakuan) yaitu norma tingkah laku yang telah digariskan oleh masyarakat (norma kesopanan, kesusilaan, adat, agama dan norma hukum). Sehingga obyek kriminologi tidak saja perbuatan yang bertentangan degan hukum, tetapi tingkah laku masyarakat yang tidak disukai, meskipun tingkah laku tersebut bukan merupakan pelanggaran dalam hukum pidana (Topo S., 2011). Wolfgang dalam Sociology of Crime and Delinquency memberikan definisi kriminologi adalah kumpulan ilmu pengetahuan tentang kejahatan yang bertujuan untuk memperoleh 
pengetahuan dan pengertian tentang gejala kejahatan dengan jalan mempelajari dan menganalisa secara ilmiah keterangan, keragaman, pola-pola dan faktor-faktor kausal yang berhubungan dengan kejahatan, pelaku kejahatan serta reaksi masyarakat. Sehingga obyek studi kriminologi adalah:

1. Perbuatan yang disebut kejahatan

2. Pelaku kejahatan

3. Reaksi masyarakat yang ditujukan baik terhadap perbuatan atau pelakunya (Topo S., 2011).

\section{Perkembangan Kriminologi}

Perkembangan kriminologi sudah sejak berabad-abad lamanya, dapat dikategorikaan berdasarkan :

\section{Berdasarkan Periode}

\section{Pada zaman Kuno}

Kejahatan merupakan suatu fenomena sosial yang dapat dipahami oleh berbagai sisi yang berbeda. Usaha memahami kejahatan tersebut sebenarnya sudah dilakukan berabad-abad. Plato (427347 SM) dalam bukunya Republik, menyatakan bahwa emas dan manusia adalah sumber dari banyak kejahatan. Aristoteles (382322 SM) menyatakan bahwa kemiskinan menimbulkan kejahatan dan pemberontakan. Kejahatan yang besar tidak diperbuat untuk memenuhi kebutuhan pokok, tetapi untuk kemewahan (Topo S., 2011). Kemudian kegelisahan Thomas More dalam Utopia bahwa hukuman berat yang dijatuhkan kepada penjahat pada waktu itu tidak berdampak banyak untuk menghapuskan kejahatan. Untuk itu, harus dicari sebab musabab kejahatan dan menghapuskannya (Santoso, 2011).

\section{Zaman Abad Pertengahan}

Van Kan merintis pertumbuhan kriminologi dengan orientasi sosiologi kriminal. Sementara itu Thomas Van Aquino (1226- 
1274) mengemukakan pendapat bahwa kemiskinan dapat menimbulkan kejahatan sedangkan orang kaya yang hidup bermewah-mewah akan menjadi pencuri jika jatuh miskin. Dan kemiskinan memberi dorongan mencuri. Pandangan ini membenarkan pencurian jika dalam keadaan memaksa (B. Simanjutak, 1977, 32).

\section{Permulaan Sejarah Baru (abad ke-16)}

Merupakan zaman kelahiran kriminologi dalam arti sempit karena Thomas More membahas hubungan kejahatan dan masyarakat. Dia mengkritik pemerintahan Inggris yang menghukum penjahat terlalu keras serta mengatakan kejahatan hanya berkurang bila ada perbaikan hidup, bukan hukuman yang keras. Mengecam susunan hukum pidana dimana berlaku hukuman mati untuk pencurian, tetapi setuju penjahat harus menebus dosanya (B. Simanjutak, 1977).

\section{Abad ke-18 hingga Revolusi Perancis}

Pada abad ini mulai ada penentangan terhadap hukum pidana yang ditujukan untuk menakuti dengan penjatuhan hukuman penganiayaan. Pribadi penjahat tidak diperhitungkan sehingga pembuktian tergantung dari kemauan si pemeriksa dan tersangka. Sehingga mulai muncul reaksi terhadap hukum pidana. Keadaan ini juga disokong oleh Aufklarung yang menginginkan adanya keadilan. Beberapa tokoh yang muncul;

a. Montesquieu (1755, Perancis) menentang tindakan sewenangwenang hukuman yang kejam. Pembentuk UU yang baik harus lebih menjelaskan pencegahan kejahatan daripada penghukuman.

b. Rosseau (1778, Perancis) melawan perlakuan kejam yang diberlakukan kepada penjahat.

c. Voltaire (1778, Perancis) pembela Jean Cals yang tidak berdosa dan dijatuhi hukuman mati dan menentang peradilan pidana yang sewenang-wenang. 
d. J. Bentham (1748, Inggris), menciptakan aliran utilitarisme, yang merencanakan lembaga pemasyarakatan model baru.

e. Mannheim (1780, Jerman), upaya memberantas kejahatan.

f. H. Calkoen (1818, Belanda), penyebab kejahatan adalah kemiskinan dan pengangguran, anak terlantar dan gelandangan. Pencegahnya dilakukan dengan pendidikan olahraga bagi masyarakat (B. Simanjutak, 1977).

\section{Revolusi Perancis hingga abad ke-19}

Revolusi Perancis (1791) mengakhiri hukum pidana (dijelaskan tentang REVOLUSI PERANCIS) - tiap manusia sama di muka undang-undang. Yang berpengaruh di Belanda dan Inggris dengan melakukan pembenahan terhadap penjara. Akan tetapi masih ada anggapan bahwa penjahat itu dianggap sama pada masa revolusi industri. Industrialisasi menyebabkan ketimpangan sosial antara kelas majikan dan buruh.

\section{Berdasarkan Pendekatan}

\section{Spiritualisme}

Pada awal perkembangan peradaban manusia, yang bisa kita jumpai dalam hukum adat dalam masyarakat, spiritualisme memiliki perbedaan mendasar dengan metode penjelasan kriminologi saat ini. Penjelasan spiritualisme memfokuskan perhatiannya pada perbedaan antara kebaikan yang datang dari Tuhan atau Dewa dan keburukan yang datang dari setan. Artinya seseorang yang telah melakukan suatu kejahatan dipandang sebagai orang yang telah terkena bujukan setan. Misalnya; bencana alam, pagebluk sebagai akibat banyak orang melanggar normanorma. Kemudian berkembang metode pembuktian kesalahanmisalnya di Madura ada konsep Carok, yaitu membuktikan siapa yang bersalah dengan cara pertandingan antara keluarga korban dan keluarga pelaku. Yang kalah berarti mereka adalah pelaku kejahatan. Kelemahannya adalah tidak bisa dibuktikan secara ilmiah (Topo, 2011). 


\section{Naturalisme}

Perkembangannya dipengaruhi oleh aliran rasionalisme yang berkembang di Eropa. Sebagaimana pernyataan Hipocrates, the brain is organ of the main (460 SM).

Aliran ini dibagi menjadi;

a. Klasik

Dasar pemikirannya adalah pada dasarnya manusia adalah makhluk yang memiliki kehendak bebas (free will), dimana dalam bertingkah laku ia memiliki kemampuan untuk memperhitungkan segala tindakan berdasarkan keinginannya (hedonisme). Beccaria kemudian menjelaskan adanya persamaan di hadapan hukum bagi semua orang keadilan dalam penerapan sanksi. Ia menginginkan kesebandingan antara tindakan dan hukuman yang dijatuhkan. Bentham mengatakan bahwa tujuan pemberian sanksi adalah alat preventif bagi lahirnya kejahatan. Mengilhami Code Civil Napoleon; kepastian hukum-hukum tertulis, persamaan hukum-menentang keberpihakan dalam hukum dan keseimbangan antara kejahatan dan hukuman.

b. Neo Klasik

Menginginkan perubahan dari mazab sebelumnya, karena justru menimbulkan ketidakadilan, penghukuman anak di bawah umur, aspek-aspek kondisi pelaku dan lingkungannya.

c. Positivis, terbagi menjadi;

1) Determinisme biologis, perilaku manusia sepenuhnya tergantung pada pengaruh biologis yang berada di dalam dirinya.

2) Determinasi kultural, kehidupan seseorang dipengaruhi juga oleh sosial, budaya dan lingkungan dimana dia hidup (Topo S., 2011). 
Cesare Lambroso, Bapak Kriminologi Modern atas jasanya melahirkan Born Criminolgy dan meletakan metode ilmiah dalam mencari penjelasan tentang sebab kejahatan serta melihatnya dari banyak faktor. Born Criminal dipengaruhi oleh Darwin tentang evolusi manusia, yang membantah tentang free will yang dimiliki oleh manusia. Doktrin Atavisme yang membuktikan adanya sifat hewani yang diturunkan oleh nenek moyang manusia. Dalam perkembangan teorinya ini Lombroso mendapati kenyataan bahwa manusia jahat dapat ditandai dari sifat-sifat fisiknya. Penjahat dibagi menjadi empat golongan;

a. Born criminal, orang yang berdasarkan doktrin atavisme

b. Insane criminal, orang-orang yang tergolong kelompok idiot, embisil dan idiot

c. Occasional criminal, pelaku kejahatan berdasarkan pengalaman yang terus menerus sehingga mempengaruhi pribadinya

d. Criminal of passion, yaitu pelaku kejahatan yang melakukan tindakannya karena marah, cinta atau kehormatan (Topo S., 2011).

Beberapa Ajaran Lombrosso;

a. Penjahat sejak lahir merupakan tipe khusus.

b. Tipe ini dikenali dari bentuk atau cacat tertentu.

c. Keanehan tersebut merupakan takdir sebagai penjahat dan kepribadian ini sebagai akibat atavisme.

d. Karena keadaan ini, orang yang memiliki kondisi fisik tersebut tidak bisa menghindarkan diri, kecuali dalam keadaan beruntung.

e. Golongan atau kelas penjahat memiliki tanda dan cap yang berbeda-beda.

Selain Lombrosso, ada beberapa teori lagi yang menitikberatkan pada kondisi penjahat;

a. Teori Psikis, sebab kejahatan dihubungkan dengan kondisi kejiwaan seseorang dengan menggunakan tes IQ, yakni 
rata-rata dibawah 100, penjahat adalah yang memiliki keterbelakangan mental atau bodoh.

b. Teori yang menyatakan bahwa penjahat memiliki bakat yang diwariskan oleh orang tuanya.

c. Teori Psikopati; kejahatan disebabkan oleh kondisi jiwanya yang tidak sehat, tidak memiliki kesadaran terhadap kejahatan yang diperbuatnya.

d. Kejahatan sebagai gangguan kepribadian, yang memunculkan istilah crime without victim, pemabuk, perjudian.

Enrico Ferri, menengahinya dengan merangkum beberapa pendapat dari para ahli, bahwa ada orang-orang yang dilahirkan jahat, namun lingkungan pun memiliki pengaruh dalam membentuk perilaku jahat tersebut.

Disamping penyebabnya adalah individu, ada beberapa kelompok yang mencari sebab kejahatan karena pengaruh sosial kebudayaan;

a. Menghubungkan kejahatan dengan ekonomi.

b. Kejahatan sebagai perilaku yang dipelajari secara normal.

c. Konfik kelompok sebagai penyebab kejahatan.

d. Teori kritis atau modern.

Tabel.4 Sejarah Perkembangan Akal Pemikiran Manusia

\begin{tabular}{|l|c|l|l|}
\hline \multicolumn{1}{|c|}{ Ajaran } & $\begin{array}{c}\text { Tahun } \\
\text { berkembang }\end{array}$ & \multicolumn{1}{|c|}{ Isi Penjelasan } & \multicolumn{1}{|c|}{ Metode } \\
\hline Klasik & 1775 & Hedonisme & $\begin{array}{l}\text { Kursi sandar } \\
\text { lengan }\end{array}$ \\
\hline Kartografik & 1830 & $\begin{array}{l}\text { Ecology, cultur, } \\
\text { komposisi } \\
\text { penduduk }\end{array}$ & $\begin{array}{l}\text { Peta-peta } \\
\text { statistik }\end{array}$ \\
\hline Sosialis & 1850 & $\begin{array}{l}\text { Determinisme } \\
\text { ekonomi }\end{array}$ & Statsitik \\
\hline
\end{tabular}


DEFINISI \& PERKEMBANGAN KRIMINOLOGI

\begin{tabular}{|l|c|l|l|}
\hline $\begin{array}{l}\text { Typology; } \\
1 .\end{array}$ & 1875 & $\begin{array}{l}\text { Type morfologis, } \\
\text { Lom criminal } \\
\text { Lelemahan pikiran }\end{array}$ & Klinis, statistik \\
2. Mental & 1905 & $\begin{array}{l}\text { Klinis, tes, } \\
\text { statistik } \\
\text { Tes }\end{array}$ & Klinis, statistik \\
3. & & & \\
Psychiatris & 1905 & $\begin{array}{l}\text { Proses-proses } \\
\text { kelompok dan } \\
\text { Sosial }\end{array}$ & $\begin{array}{l}\text { Klinis, statis- } \\
\text { tik }\end{array}$ \\
\hline Sosiologis & 1915 & & \\
\hline
\end{tabular}

Sumber: Topo S., 2011 
BAB VIII

Teori Tentang Kejahatan 


\section{Penyebab Kejahatan}

Sebab-Sebab Kejahatan, bisa dilihat dari berbagai segi:

\section{Dari Aspek Fisik (Biologi Kriminal)}

Pemikiran ini dipelopori oleh ahli Frenologi, yang mencari hubungan antara bentuk tengkorak dan tingkah laku. Pendapat ini berdasarkan pendapat Aristoteles, bahwa otak merupakan organ dari akal. Karena otak merupakan organ, maka benjolanbenjolannya merupakan petunjuk dari kemampuan/ kecakapan tertentu dari organ (Susanto, 2011. Pemahaman tersebut mendorong beberapa ahli untuk mencari hubungan antara kejahatan dan biologis. Tokoh yang berhasil membuktikan itu adalah Cesare Lombroso, yang termasuk Aliran Klasik. Beberapa Ajaran Lombrosso;

a. Penjahat sejak lahir merupakan tipe khusus.

b. Tipe ini dikenali dari bentuk atau cacat tertentu.

c. Keanehan tersebut merupakan takdir sebagai penjahat dan kepribadian ini sebagai akibat atavisme.

d. Karena keadaan ini, orang yang memiliki kondisi fisik tersebut tidak bisa menghindarkan diri, kecuali dalam keadaan beruntung.

e. Golongan atau kelas penjahat memiliki tanda dan cap yang berbeda-beda (Topo S., 2011) 
Pemikiran Lambroso ini muncul karena analisisnya terhadap dunia hewan dan masyarakat yang memiliki kebudayaan saling membunuh (mengayau). Bahwa perempuan adalah pelacur, sedangkan laki-laki adalah pembunuh, pencuri dan pemerkosa (Susanto, 2011:50). Usaha mencari hubungan antara kejahatan dan ciri-ciri biologis tertentu ini, misalnya analisis tentang kejahatan yang melibatkan laki-laki atau perempuan. Pandangan ini juga dipengaruhi oleh pendapat Aristoteles yang berputar pada teori Nature (perbedaan laki-laki dan perempuan disebabkan oleh faktor-faktor biologis) dan Nurture (perbedaan laki-laki dan perempuan karena belajar dengan lingkungan). Hasil analisisnya menunjukan bahwa kejahatan yang dilakukan oleh laki-laki lebih besar dibandingkan dengan kejahatan yang dilakukan oleh perempuan, kecuali aborsi. Akan tetapi seiring dengan perubahan nilai-nilai budaya, sebagai akibat berkembangnya gerakan perempuan, maka banyak muncul kejahatan yang disebabkan oleh perempuan.

Pada tahun 1920, menurut Kretchmer, tipe dasar manusia berdasarkan biologi Kriminal dibedakan menjadi;

a. Tipe Leptosome, yang mempunyai bentuk jasmani tinggi, kurus dengan sifat pendiam, dingin dan bersifat tertutup dan menjaga jarak. Sering melakukan tindak kejahatan pemalsuan.

b. Tipe Piknis, mempunyai bentuk tubuh pendek, kegemukan dan sifat yang riang, cenderung melakukan tindak kejahatan penipuan dan pencurian.

c. Tipe Atletis, mempunyai bentuk tulang dan otot yang kuat, dada lebar, dagunya kuat dan rahang menonjol, sifatnya agresif, cenderung melakukan tindak kejahatan kekerasan dan seksual (Susanto, 2011).

Antitesa terhadap pemikiran Lambroso ini adalah Lacassagne, yang menurutnya berkembang tidaknya suatu tindak kejahatan berdasarkan kondisi masyarakat. Dia menganalogikan dengan 
bakteri, yang bisa berkembang ataukah tidak dipengaruhi oleh tempatnya. Jika tempatnya steril tidak berkembang, begitu pula sebaliknya. Demikian juga kejahatan (Santoso, 51). Enrico Ferri kemudian membuat analisis dengan tetap menggunakan analisis Lambrosso. Menurutnya kejahatan adalah resultant dari keadaan individu, fisik dan sosial, yang dapat digambarkan;

$$
\text { Kejahatan }=\text { individu }+ \text { sosial }+ \text { fisik }
$$

Sumber: Susanto, 2011

Sedangkan individu dapat dikembangkan menjadi:

Individu = Bakat (jahat) + lingkungan (manusia) + lingkungan (alam)

$$
\text { Sumber: Susanto, } 2011
$$

Ferri menyatakan рanwa tınaak кеjahatan yang paling dominan tetap dipengaruhi oleh bakat seseorang untuk berbuat jahat, sedangkan faktor di luar dirinya lebih mempengaruhi bentuk-bentuk kejahatan

\section{Dari Aspek Psikologis dan Psikiatris (Psikologi Kriminal)}

Pandangan ini berdasarkan pendapat bahwa penjahat merupakan orang-orang yang memiliki psikis yang berbeda dengan orang-orang yang bukan penjahat, yang ciri psikis tersebut terletak pada intelegensianya yang rendah. Psikologi kriminal adalah ilmu yang mempelajari ciri-ciri psikis dari para pelaku kejahatan yang sehat menurut pengertiaan psikologi, dibagi menjadi:

\section{Psikoses}

a. Psikoses Organis (Susanto, 2011:58)

1) Kelumpuhan umum dari otak yang ditandai dengan kemerosotan kepribadian - penipuan, pencurian, pemalsuan. 
2) Traumatik Psikoses yang mengakibatkan luka pada otak yang disebabkan dari kecelakaan (gegar otak).

3) Encephalis Lethargica, pelakunya anak-anak yang melakukan tindakan anti sosial dan pelanggaran seks

4) Senile Dementia, penderita umumnya pria lanjut yang mengalami kemunduran mental dan emosional, cenderung melakukan pelanggaran seks pada anakanak.

5) Puerperal Insanity, penderitanya adalah wanita hamil atau beberapa saat sebelum melahirkan dengan cara aborsi.

6) Epilepsy dengan bentuk gangguan yang bermacammacam.

7) Psikoses yang diakibatkan oleh alkohol.

\section{b. Psikoses Fungsional}

1) Paranoia, penderitanya diliputi khayalan tingkat tinggi, merasa hebat dan merasa dikejar-kejar.

2) Manic-Depresive Psikhoses, menunjukan tandatanda perubahan kegembiraan yang berlebihan ke kesedihan-kekerasan, bunuh diri, pencurian, penipuan.

3) Schizoprenia, sebagai bentuk psikoses fungsional yang paling banyak. Lari dari kenyataan, hidup penuh fantasi dan halusinasi dan tidak bisa memahami orang lain.

\section{Neuroses}

a. Anxiety Neurosis (Phobia), ketakutan yang berlebihan terhadap adanya bahaya dari sesuatu atau pada sesuatu yang tidak sama sekali- pengaruh ideologi tertentu.

b. Hysteria-terdapat disosiasi antara dirinya dan lingkungannya, sangat egosentris, emosional dan suka bohong. 
c. Obsesional — memiliki ide-ide atau keinginan yang tidak rasional dan tidak dapat ditahan. Kleptomaniaseksual yang ditekan karena ketakutan terhadap norma (Susanto, 2011)

\section{Cacat mental}

Menekankan pada kekurangan intelegensia daripada karakter dan kepribadian. Orang yang memiliki IQ rendah atau tinggi yang berbeda dengan orang normal.

Psikologi (normal) dan penjahat; Ciri-ciri pelaku kejahatan adalah;

a. Penelitian terhadap 100 napi, 51\% adalah kepribadian yang samar-samar atau tidak efektif. Disamping itu ada kepribadian yang tidak dewasa.

b. Pelaku kejahatan lebih banyak frustasi daripada ratarata, lebih frustasi dan agresif; misalnya; kebutuhan rasa aman, kebutuhan memperoleh pengalaman, pemenuhan kebutuhan cinta dan kebutuhan untuk memperoleh status atau prestise (Santoso, 2011:72).

\section{Dari Aspek Sosiologis-Kultural (Sosiologi Kriminal)}

Dengan menggunakan dua pendekatan;

a. Penyimpangan sebagai kenyataan obyektif

1) Adanya norma-norma yang berlaku di masyarakat

2) Adanya kondisi sosial yang mendorong terjadinya perilaku kejahtan

b. Penyimpangan sebagai problematika subyektif

1) Persoalann pokoknya adalah bagaimana kelompok atau masyarakat memberi batasan tentang penjahat dan kejahata Penyebab kejahatan;

a. Permasalahan kelas

b. Di luar kelas; lingkungan, konflik, ekonomi dll 


\section{Kejahatan Dalam Perspektif Psikologis}

\section{Personality Characteristic (Sifat-sifat Kepribadian)}

Empat model kajian psikologis hubungan antara kepribadian dan kejahatan;

1) Perbedaan antara struktur kepribadian penjahat dan bukan penjahat.

2) Memprediksi tingkah laku.

3) Menguji tingkatan dimana dinamika kepribadian normal beroperasi dalam diri penjahat.

4) Menghitung perbedaan-perbedaan individual antara tipetipe dan kelompok-kelompok pelaku kejahatan (Topo S., 2011:49).

\section{Samuel Yochelson dan Stanton Samenow}

Keduanya berpendapat bahwa para penjahat itu samasama memiliki pola berpikir abnormal sehingga memutuskan untuk berbuat jahat, identifikasi yang mereka lakukan adalah sebanyak 52 pola. Para penjahat merupakan orang yang "marah", yang merasakan suatu sense superioritas, menyangka tidak bertanggungjawab atas tindakan yang diambil dan mempunyai harga diri yang melambung, tiap dia merasakan ada serangan terhadap harga dirinya tersebut, ia akan memberikan reaksi yang sangat kuat dan melakukan kekerasan atau tindak kejahatan (Topo S., 2011:49).

\section{Mental Disorder}

Pada orang dewasa, penyakit mental ini disebut sebagai Psychopathy atau Antisocial personality, atau suatu kepribadian yang ditandai oleh suatu ketidakmampuan belajar dari pengalaman, kurang kehangatan/keramahan dan tidak merasa bersalah.

Beberapa cirri psychopath; tidak menghargai kebenaran, tidak tulus, tidak merasa malu, bersalah atau terhina, memperlihatkan kesehatan mental tetapi yang nampak itu adalah mask of sanity 
atau topeng kewarasan, berbohong dan melakukan kecurangan tanpa ada keraguan dan melakukan pelanggaran verbal atau fisik tanpa perencanaan (Topo S., 2011:50).

\section{Teori Psikoanalisa, Sigmun Freud}

Menurutnya bahwa tindakan kriminalitas merupakan hasil dari an overative conscience yang menghasilkan rasa tidak benar yang sangat berlebihan. Pelaku kriminal ini melakukan tindakan kejahatan dengan tujuan agar mendapatkan hukuman, dengan adanya tindakan penghukuman tersebut, rasa bersalah yang teramat sangat akan sedikit terkurangi. Menurutnya bahwa tindakan kriminalitas merupakan hasil dari an overative conscience yang mengahasilkan rasa tidak benar yang sangat berlebihan. Pelaku kriminal ini melakukan tindakan kejahatan dengan tujuan agar mendapatkan hukuman, dengan adanya tindakan penghukuman tersebut, rasa bersalah yang teramat sangat akan sedikit terkurangi.

Superego ini terbentuk melalui proses pelembagaan yang sangat panjang, bisa dari orang tua/komunitas/organisasi/ ideologi berupa norma, nilai dan aturan yang harus dipatuhi oleh seseorang yang membentuk kepribadian seseorang. Di sisi yang lain, dalam perkembangan seseorang tersebut ada suatu id yang muncul dan itu bertentangan dengan superego yang sudah melekat dalam dirinya, maka seseorang tersebut akan melakukan tindakan kejahatan (delinquent).

Pendekatan psikoanalisis dalam mempelajari kejahatan adalah;

1) Tindakan atau tingkah laku orang dewasa saat ini dapat dipelajari dengan menyelidiki tahap perkembangan pada masa kanak-kanak orang tersebut.

2) Tingkah laku dan motif-motif bawah sadar adalah jalin menjalin dan interaksi itu harus diuraikan untuk mengerti tentang tindak kriminal.

3) Kejahatan muncul karena representasi dari konflik psikologis (Topo S., 2011:51). 


\section{Personality Traits/ Inherited Crimanality}

Yang banyak melakukan penelitian tentang personality traits (sifat kepribadian) ini adalah Dugdale, pada awal abad ke-19. Ketidakcakapan kepribadian menurutnya merupakan sifat bawaan yang diwariskan melalui gen-gen, misalnya feeblemindedness (lemah pikiran), insanity (penyakit jiwa), stupidity (kebodohan) dan dull wittedness (bodoh). Dalam bukunya, The Jukes, yakni sebuah keluarga yang melakukan tindak kejahatan karena mereka menderita degeneracy and innaty depravity (kemerosotan dan keburukan bawaan) (Topo S., 2011:52).

\section{Moral Development Theory}

Lawrence Kohlberg, penggagas teori perkembangan moral, menyatakan bahwa pertumbuhan moral mengalami 3 tahap perkembangan;

1) Preconventinal Stage

Aturan moral atau nilai-nilai yang berkembang pada anak adalah lakukan dan jangan lakukan untuk menghindari penghukuman.

2) Conventional Level

Seseorang sudah mulai mengadopsi peraturan dan nilainilai yang berkembang di masyarakat, untuk kemudian menyimpulkan bahwa tindakan yang dilakukannya itu benar atau salah sesuai dengan aturan yang berkembang dalam masyarakat. Misalnya, ketika korupsi adalah tindakan yang melanggar hukum dan norma masyarakat, maka seseorang akan cenderung menghindarinya.

3) Post Conventional Level

Seseorang sudah mulai kritis terhadap sosial order, HAM ataupun tugas-tugas yang harus dilaksanakan dalam bermasyarakat, benarkah seseorang mendapatkan hukuman sesuai dengan perbuatannya. 
Menurut Kohlberg, tindak kejahatan yang dilakukan oleh seseorang itu berada pada tahap prakonvensional yang ditopang dengan ikatan sosial yang tidak mendukung (Topo S., 2011:53).

Menurut Psikolog yang lain, John Bowlby, kebutuhan akan kehangatan dan kasih sayang itu merupakan bagian penting dalam hidup manusia, ketika seseorang tidak mendapatkannya, maka akan menyebabkan tindakan kejahatan muncul. Tindakan kasih sayang itu diantaranya;

1) Kasih sayang jangka panjang

2) Kasih sayang yang selektif

3) Melibatkan emosi (perasaan)

4) Ontogeny (kasih sayang yang terbentuk karena figur yang kuat)

5) Learning (kasih sayang karena hasil interaksi sosial )

6) Organization (kasih sayang mengikuti organisasi perkembangan)

7) Perilaku kasih sayang yang memiliki kecenderungan kearah biologis

Seorang penjahat tidak mampu mewujudkan dan mendapatkan ketujuh unsur kasih sayang tersebut. Psikolog yang lain Joan Mc Cord menghubungkan antara ibu dan penjahat. Mayoritas penjahat, biasanya kurang mendapatkan perhatian dan kasih sayang yang cukup dari ibu, atau ibunya mengalami gangguan jiwa (Topo S., 2011:54).

\section{Social Learning Theory}

Menurut kajian ini, bahwa perilaku menyimpang (delinquent) memiliki karakter yang sama dengan perilaku non delinquent. Bahwa tingkah laku tersebut akan diperbuat karena diperkuat dan mendapatkan ganjaran. Seseorang tidak melakukan suatu tindakan tertentu karena tidak diperkuat dan tidak mendapatkan ganjaran. Beberapa jalan tingkah laku yang digunakan untuk mempelajari tingkah laku tersebut adalah dengan; 
1) Observasi (Albert Bandura)

Kekerasan atau agresi dilakukan oleh seseorang dengan meniru atau mencontoh dari lingkungan. Apa yang dilihat, didengar dan dirasakan akan membentuk perilaku kejahatan. Peniruan bisa diperoleh dari keluarga, media, lingkungan sosial. Seseorang yang melihat bahwa seseorang yang melakukan tindakan kejahatan atau kekerasan dan diterima oleh masyarakat, maka dia akan percaya bahwa tindakan kejahatan tersebut bukan suatu kesalahan. Demikian sebaliknya.

2) Direct Experience (Gerard Patterson)

Kejahatan yang dilakukan oleh seseorang merupakan kejahatan balasan karena sebelumnya dia menjadi korban. Seseorang belajar tentang kejahatan melalui trial dan error.

3) Differential Reinforcement ( Ronald Akers dan Ernest Burgess)

Teori ini menggabungkan antara psikolog Albert Bandura dan Sutherland yang cenderung sosiologis, differential association. Menurut teori ini, bertahan atau tidaknya suatu tindak kriminal tergantung dari penghargaan dan pengukuman yang diberikan oleh orang lain terhadap pelaku kejahatan; keluarga, kelompok, asosiasi, pendidikan dan lainnya. Jika tindakan kriminal mendatangkan penghargaan maka akan bertahan.

\section{Kejahatan Dalam Perspektif Sosiologis}

Dalam kategoi Sosiologi dikelompokan menjadi 3 pandangan

1. Strain

2. Cultural deviance (penyimpangan budaya)

3. Social Control (Topo S., 2011)

Perspektif strain dan penyimpangan budaya, terbentuk pada tahun 1925 dan 1940 dengan memusatkan perhatian pada kekuatan-kekuatan sosial (social forces) yang menyebabkan orang melakukan aktivitas kriminal. Sementara itu teori kontrol sosial 
menjelaskan bahwa perilaku orang berbuat jahat merupakan bagian dari kehidupan manusia.

\section{Strain}

1) Anomie; Emile Durkheim

Menurutnya perbuatan salah yang dilakukan oleh manusia, bukan terletak pada individu seseorang akan tetapi pada masyarakat, kelompok atau organisasi sosial. Konteks sosial yang mendorong manusia melakukan tindak kejahatan karena hancurnya tatanan dan nilainilai sosial. Yang dia kaji adalah perubahan yang terjadi pada masyarakat sederhana menuju masyarakat komplek. Perubahan masyarakat tersebut memerlukan perangkat tata nilai, ikatan-ikatan sosial yang baru yang sebelumnya belum ada kemudian ada dan sebaliknya atau terjadi perubahan yang sangat mendadak maka muncul lah kondisi anomie.

Sebagai contoh, pada masyarakat modern, ketergantungan seseorang terhadap orang lain sangat minim, sehingga hal ini mendorong seseorang lebih mementingkan dirinya sendiri daripada orang lain. Orang lebih enjoy dengan dunianya sendiri, membaca buku, surfing dan browsing lewat HP atau Ipad daripada bertegur sapa dengan orang lain, situasi ini memunculkan tata nilai atau norma dalam masyarakat yang menonjolkan kepentingan individu daripada kolektif, ditunjang dengan perkembangan teknologi yang memfasilitasi penonjolan kepentingan individu tersebut. Coba bayangkan, apabila masyarakat Indonesia yang sangat kolektif tersebut tibatiba dan mendadak harus berubah menjadi masyarakat modern. Masyarakat yang sangat kolektif, terbukti jika dalam masyarakat dijumpai adanya penjahat, maka seluruh desa ikut menghakimi penjahat tersebut, kemudian digiring untuk berubah menjadi masyarakat modern, dengan 
berbagai macam perangkat teknologi yang sedemikian rupa termasuk kebijakannya? Bagaimana dan apa yang kemudian terjadi? Ketika kita yang biasa bertegur sapa dengan orang lain, tiba-tiba tidak ada orang yang diajak bertegur sapa? Maka itulah yang disebut anomie.

Situasi yang berubah menjadikan perubahan tatanan sosial dan norma dalam masyarakat yang itu menjadi sebuah fakta sosial atau kenyataan obyektitif; fakta sosial merupakan hal yang bersifat eksternal dari individu, fakta sosial itu memaksa individu, fakta sosial bersifat umum dan terpublikasi secara luas dalam masyarakat dan terdapat kaidah hukum yang membedakan dengan fakta sosial yang lain, karena pelembagaan kode hukum oleh Negara (Robert Lawang, 177).

Demikian halnya pada situasi dimana terjadi perubahan keadaan ekonomi yang sangat mendadak, dari dahulunya sangat kaya secara tiba-tiba menjadi tidak kaya dalam jumlah yang banyak karena krisis ekonomi yang terjadi di suatu negara, akan menyebabkan masyarakat dalam kondisi anomie dan menimbulkan bunuh diri (suicide).

Dalam konteks masa Durkheim adalah pada tahun 1920-an merupakan tahun-tahun yang penuh harapan bagi masyarakat karena banyaknya keuntungan yang diperoleh dari pasar modal, namun pada tahun 1929, secara tibatiba terjadi kebangkrutan pasar modal yang menyebabkan banyak orang yang mengalami kehilangan pekerjaan dalam jumlah banyak, yang menyebabkan depresi dan masyarakat mengalami keputusasaan. Hal inilah yang menyebabkan terjadi anomie dan menimbulkan berbagai macam perilaku sosial yang baru, dalam konteks ini suicide.

Bagaimana Anda membaca pada konteks 1998 di Indonesia? Menurut Durkheim, ledakan kemakmuran atau keruntuhan yang secara mendadak, akan merunuhkan 
sistem sosial yang lama dan terbentuk yang baru. Pada masa anomie itulah sangat rentan dengan perilaku-perilaku menyimpang.

2) Strain Theory; Robert K.Merton

Analisis Merton tidak jauh berbeda dengan Durkheim tentang anomie, yang membedakan analisisnya adalah penyebab anomienya. Jika Durkheim menyatakan penyebabnya adalah perubahan sosial yang mendadak dan sangat cepat, sementara Merton lebih menyoroti tentang struktur sosial yang menawarkan mimpi dan tujuan yang sama akan tetapi tidak memiliki sarana dan perangkat yang sama untuk mencapai tujuannya. Merton menekankan 2 unsur penting dalam masyarakat, yakni; cultural aspiration (goal) dan institutionalized means yang seharusnya terintegrasi.

Sebagai contoh: dalam masyarakat konsumen saat ini, masyarakat tanpa memandang kelasnya disuguhi oleh berbagai macam produk yang "memaksa" untuk dibelinya. Mulai dari peralatan elektronik; HP, laptop, peralatan rumah tangga, produk kecantikan, sarana transportasi sampai dengan produk makanan. Sehingga alam pikiran dan alam rasanya ingin memiliki berbagai macam produk tersebut sebagai bagian dari hidupnya untuk disebut sebagai manusia yang tidak ketinggalan zaman, update dan kelompok-kelas sosial ditentukan oleh kepemilikan barang-barang tersebut. Bagi masyarakat kelas atas yang memiliki banyak materi tentu tidak menjadi persoalan untuk mendapatkan barangbarang itu, tetapi bagi masyarakat yang tidak memiliki kekayaan apa pun akan menjadi persoalan. Beberapa fakta: seorang anak rela diambil ginjalnya hanya untuk membeli ipad dan IPhone di China, sedangkan di Indonesia, mayoritas pekerja akan membelanjakan penghasilannya untuk membeli suatu produk tertentu, BB, IPad, Galaxy 
tab dan sebagainya. Masyarakat yang tidak memiliki daya beli suatu produk tertentu, sementara keinginannya sangat kuat untuk memilikinya, cenderung akan melakukan perilaku yang menyimpang, termasuk tindak kejahatan dengan berbagai macam bentuk.

Dalam skala yang luas dan banyak masyarakat yang mengalami hal yang sama, maka akan menyebabkan terjadinya keruntuhan sistem nilai dalam masyarakat. Contoh; jika dicek banyak diantara masyarakat melakukan tindak koruptif, dari level atas sampai bawah, sebagai salah satu cara untuk memenuhi hasrat di satu sisi sumber daya yang dimiliki sangat terbatas.

Dalam masyarakat yang berorientasi kelas ini, kesempatan bagi masyarakat untuk menduduki kelas atas ini tidak dibagi dengan merata, artinya masyarakat tidak memiliki kesempatan yang sama, sangat sedikit masyarakat kelas bawah yang bisa mendukui kelas atas ini. Walaupun ada peluang atau kesempatan untuk menduduki kelas atas tadi, melalui legitimate means (misalnya; pendidikan, bahasa, bekerja keras, keluarga) (Topo S., 2011:61). Jika kita lihat, sangat sedikit orang kelas bawah yang mampu menduduki kelas yang lebih atas.

Analisis Merton dilakukan pada masyarakat Amerika, mobilitas sosial dapat menyebabkan terjadinya penyimpangan karena legitimate means tersebut menjadikan orang miskin memiliki beban untuk meraih goal, faktanya yang meraih kesuksesan pada golongan ini adalah yang memiliki talenta yang lebih dibandingkan yang lain. Sementara mayoritas orang miskin tidak mendapatkan goal-nya karena keterbatasan means. Hal inilah yang menimbulkan strain. 


\section{Modes Adaptation}

Pada kondisi strain tersebut, ada 2 model adaptasi yang dilakukan oleh masyarakat:

1. Positif - conformity - tetap berusaha untuk mencapai goal dengan ketekunan

2. Perilaku menyimpang

a. Innovation- meyakini goals, tetapi menggunakan illegimate means

b. Ritualisme- menghindari resiko dan hidup dalam batas-batas rutinitas sehari-hari

c. Retreatism- mengalihkan dengan cara yang meyimpang-alkohol, drug, bunuh diri

d. Rebellion-perlawanan (Topo S., 2011)

Strain theory lebih memfokuskan pada tindak kejahatan yang dilakukan oleh warga masyarakat karena proses adaptasi dari kelas yang lebih dominan, dalam hal ini kelas menengah, terutama kesuksesan secara ekonomi.

\section{Cultural Deviance}

Cultural deviance mengkaji bahwa tindak kejahatan yang berdasarkan kelas, dan yang banyak melakukan tindak kejahatan adalah lower class berikut tata nilai yang berkembang dalam masyarakat kelas bawah untuk kemudian mempengaruhi dimana mereka tinggal. Baik strain theory atau cultural deviance lebih "menuduh" bahwa tindak kejahatan banyak dilakukan oleh masyarakat miskin (Topo S., 2011:67).

Cultural deviance beranggapan bahwa masyarakat yang satu dengan yang lain memiliki perbedaan dalam hal karakter, sosial, budaya dan nilai-nilai yang dianggap benar atau salah. Bagi masyarakat A dianggap benar, tetapi bagi masyarakat B dianggap salah dan begitu pula sebaliknya. Demikian halnya dengan masyarakat yang memiliki kecenderugan menyimpang dan tidak, akan memiliki nilai dan norma yang berbeda. Sehingga bagi 
seseorang yang menyesuaikan dengan budaya masyarakat yang menyimpang, pasti tidak dianggap menyimpang oleh masyarakat yang berkebudayaan menyimpang. Karena seseorang tersebut sudah dianggap mematuhi norma dan aturan yang berkembang dalam masyarakat tersebut. Akan tetapi dianggap sebaliknya oleh masyarakat yang tidak menyimpang.

\section{1) Social Disorganization}

Teori ini mengkaji tentang perkembangan wilayahwilayah yang memiliki tingkat kejahatan tinggi yang disebabkan oleh adanya degradasi nilai-nilai lama, nilai yang lama digantikan dengan nilai baru (tradisi kriminal) yang dipengaruhi oleh proses perkembangan industri, perpindahan penduduk dan proses tersebut ditransmisikan dari satu generasi kepada generasi di bawahnya.

Menurut W.I Thomas dan Florian Znaniecki dalam bukunya The Polish Peasant in Europe and America menggambarkan kehidupan susahnnya kehidupan petani Polandia (Polish) yang melakukan migrasi menuju perkotaan di daerah industri perkotaan (Chicago). Perpindahan wilayah dari pedesaan yang memiliki kultur yang berbeda dengan masyarakat perkotaan akan mengalami cultural shock, yang menyebabkan terjadinya tindak kejahatan. Artinya dari fenomena ini dapat disimpulkan bahwa tindak kejahatan terjadi pada daerah yang menjadi tujuan urban. Bagi masyarakat golongan tua tentu masih membawa kultur keudayaan pedesaan yang ditransmisikan di perkotaan, sehingga kelompok ini tidak mengalami goncangan kebudayaan. Dengan cara membangun kepercayaan pada kelompok migran atau menjalin relasi dengan kelompok lain yang berasal dari pedesaan.

Hal ini akan sangat kita rasakan apabila kita datang di wilayah bantaran Kali Code, akan masih terlihat karakter dan kultur pedesaan pada kalangan orang tua, terlihat dari 


\section{TEORI TENTANG KEJAHATAN}

bagaimana membawa romantisme ekonomi pedesaan; memelihara ayam, bercocok tanam serta relasi komunal masyarakat pedesaan. Yang terlihat adalah pinggiran kota, serasa desa.

Akan tetapi bagi golongan muda, tentu akan merasakan kesulitan, jika harus beromantisme dengan suasana pedesaan. Karena senyata-nyatanya mereka tidak tinggal di desa. Mereka tinggal di perkotaan dengan tingkat individualismenya sangat tinggi dan tingkat konsumsinya juga sudah sangat menggila. Mereka akan mengalami goncangan kebudayaan, sementara di sisi lain golongan tua tidak mampu melakukan transmisi kebudayaan. Pada kondisi kebudayaan seperti itu sangat rentan seseorang melakukan tindak kejahatan.

Sementara itu menurut Robert Park and Ernest Burgess mengembangkan teori sebelumnya dengan mengkaji wilayah-wilayah di perkotaan yang menjadi tempat atau sarang penjahat yang lebih banyak (angka kejahatannya tinggi) dibandingkan dengan wilayah yang lain. Pengembangannya dikenal dengan natural urban areas. Menurutnya perkotaan itu dibagi menjadi:

\section{Tabel.5 Zona Wilayah Perkotaan dan Tindakan Kriminal}

\begin{tabular}{|l|l|}
\hline Zona 1 & $\begin{array}{l}\text { berada di pusat yang disebut loop (lingkaran } \\
\text { atau putaran - tempat perkantoran, bisnis, } \\
\text { perdagangan dan administrasi pemerintahan }\end{array}$ \\
\hline
\end{tabular}




\begin{tabular}{|l|l|}
\hline Zona 2 & $\begin{array}{l}\text { merupakan wilayah transisi yang dihuni } \\
\text { oleh masyarakat miskin kota yang memiliki } \\
\text { pendidikan rendah, tinggal di perumahan } \\
\text { kumuh yang dekat dengan pabrik tua. } \\
\text { Wilayah ini yang paling tidak diinginkan, } \\
\text { menjadi tujuan para imigran, ikatan sosial } \\
\text { yang terjalin di dalamnya sangat lemah } \\
\text { sehingga menjadi sarang tindak kejahatan } \\
\text { yang menyebar di masyarakat. }\end{array}$ \\
\hline Zona 3 & $\begin{array}{l}\text { wilayah pinggiran yang menjadi tempat } \\
\text { tinggal para pekerja }\end{array}$ \\
\hline Zona 4 & $\begin{array}{l}\text { merupakan wilayah elit yang menjadi tempat } \\
\text { perumahan mewah di pinggiran kota yang } \\
\text { jauh dari pabrik dan asap kendaraan }\end{array}$ \\
\hline
\end{tabular}

Menurut Clifford Shaw da Henry McKay mengkaji lebih dalam penelitian sebelumnya dengan menggambarkan penyebaran penduduk pada zona yang berbeda-beda, yang melakukan kajian di wilayah yang sama, yakni Chicago pada tahun 1900-1993, menyatakan;

a. Angka kejahatan menyebar merata di seluruh kota. Angka yang tinggi disertai dengan problem kemasyarakatan

b. Penyimpangan banyak terjadi di wilayah yang dekat bisnis dan semakin berkurang jika menjauh dari pusat bisnis

c. Angka kejahatan yang tinggi ditandai dengan banyaknya pendatang dengan pendidikan dan pendapatan rendah

d. Beberapa wilayah memiliki angka kejahatan yang tinggi secara tetap tanpa memandang asal wilayah, suku, dan agama. 
e. Wilayah yang memiliki angka kejahatannya tinggi, terjadi pertarungan antara nilai dan norma yang menyimpang dengan nilai dan norma yang tidak menyimpang (konvensional), sementara itu nilai yang menyimpang tetap dianut oleh masyarakat setempat (Topo S., 2011:73).

2) Differential Association

Pengkajinya Sutherland dalam bukunya The Principles of Criminology, 1939, yang menjelaskan bahwa tindakan kriminal dilakukan melalui proses interaksi sosial dan seberapa besar kualitas dan kuantitas definisi kejahatan atau bukan kejahatan yang dicerna, akan menentukan dia berbuat kriminal atau non kriminal.

\section{Social Control}


BAB IX

Viktimologi dan

Pemenjaraan 
Permasalahan Viktimologi di Indonesia dibahas dalam aturan
hukum formal yaitu UUD 1945 pada pasal Pasal 27 UUD 1945 yang menyebutkan bahwa:

"Segala warga Negara bersamaan kedudukannya di dalam hukum dan pemerintahan dan wajib menjunjung hukum dan pemerintahan dengan tidak ada kecualinya”

Hal ini berlaku terhadap seluruh warga Negara, baik dia sebagai korban, pelaku dan atau saksi dalam setiap persidangan perkara pidana. Prakteknya sering terjadi pelanggaran terhadap pelaku atau korban kejahatan dalam berbagai macam bentuk, misalnya: Sebagai pelaku melakukan pengejaran, pungutan liar, intimidasi dan sebagai korban melakukan dakwaan yang lemah, tuntutan ringan atau sebaliknya, tidak menerima kompensasi.

Dalam setiap tindak kejahatan kita mengenal adanya korban dan pelaku. Akan tetapi ada beberapa kasus pidana tertentu, korban dan pelakunya menjadi satu-victimless crime- seperti narkoba dan pelacuran. Dalam persidangan pidana, kepentingan korban ini diwakili oleh penuntut umum, yang memberikan tuntutan hukuman kepada pelaku. Seringkali apa yang dituntut oleh penuntut umum/ jaksa tidak mewakili korban dan bersikap semaunya. Hal ini yang disebut dengan pelanggaran hak-hak korban.

Viktimologi berasal dari victim (korban) dan logi (ilmu pengetahuan) - pengetahuan tentang korban. Menurut UU No. 13 Tahun 2006 tentang perlindungan saksi dan korban, korban adalah: 
a. Setiap orang

b. (yang) mengalami penderitaan fisik, mental dan

c. Kerugian ekonomi

d. (yang) diakibatkan (oleh suatu) tindak pidana

Sementara itu menurut PP No.2 Tahun 2002 tentang tata cara perlindungan terhadap Korban dan Saksi-saksi dalam pelanggaran HAM Berat - setiap orang atau kelompok yang mengalami penderitaan sebagai akibat pelanggaran HAM yang berat yang memerlukan perlindungan fisik dan mental dari ancaman, gangguan, teror dan kekerasan dari berbagai pihak.

Lingkup victim;

a. Korban perseorangan; jiwa, fisik, materiil dan non materiil

b. Korban institusi- akibat kebijakan pemerintah, korupsi, terorisme, narkoba

c. Korban lingkungan hidup — bencana alam

d. Korban masyarakat, bangsa dan Negara - tidak meratanya pemenuhan hak-hak warga Negara

Korban-korban struktural, diantaranya :

a. Petani tidak memiliki tanah

b. Kebijakan struktural, misal : tindakan operasi pedagang kaki lima, pekerja seks komersial (PSK)

c. Penggusuran paksa dan tidak berikan ganti berbeda dengan petani yang memiliki tanah- punya rumah = hidup layak

d. Guru merupakan salah satu atau sebagaian korban dari kebijakan pemilik modal atau majikan atau pengusaha.

e. Rakyat bawah (jelata) sering jadi korban rugi

Dalam perkembangannya Viktimologi sudah dimulai pada abad pertengahan dengan adanya perhatian penegak hukum terhadap pelaku kejahatan. Terdapat dua pandangan terhadap viktimologi ini, ada yang berpendapat sebagai bagian dari kriminologi dan ada yang berdiri sendiri. Kajian ini menekankan bahwa viktimologi adalah bagian dari kriminologi (penjahat dan kejahatan) dan diteruskan dengan korban kejahatan viktimologi). 


\section{VIKTIMOLOGI DAN PEMENJARAAN}

Pentingnya viktimologi;

a. Setiap korban dapat memahami hak dan kewajibannya dalam mengantisipasi semua ancaman yang dihadapinya

b. Dapat digunakan korban untuk menentukan hak-haknya atas penderitaan dan kerugian yang dihadapi sebagai dampak kejahatan

c. Penyelenggara Negara dapat memberikan hak-hak korban

d. Pengembangan pengetahuan tentang korban

Pengkajian tentang korban ini perlu dilakukan mengingat dalam kenyataannya ada hubungan antara pelaku dan korban yang sangat unik. Korban bisa menjadi salah satu penyebab terjadinya tindak kejahatan.

Secara umum masyarakat berpendapat bahwa korban adalah;

a. Akibat dari tindak kejahatan

b. Pihak yang dirugikan, sedangkan pelaku adalah pihak yang mengambil keuntungan (fisik, ekonomi, mental dll)

(a, b tersebut jika korban menjadi korban murni, semata-mata menjadi korban; lalai, lupa, alpa, tidak tahu). Misalnya; kecelakaan, kecopetan, penganiayaan oleh geng motor atau kelalaian negara dalam mengurus warganya — kebijakan pemerintah—pasal 34; fakir miskin dan anak terlantar dipelihara negara.

\section{Hubungan Kejahatan dan Korban}

Dalam beberapa kasus tertentu, korban ini menjadi bagian yang penting dalam kejahatan;

1. Peranan korban dalam menimbulkan tindak kejahatan;

Tindakan kejahatan memang dikehendaki oleh korban- kasus KDRT, menginginkan harta.

Kerugian yang diderita digunakan untuk mendapatkan keuntungan yang lebih besar-pembakaran toko- asuransi.

Kejahatan merupakan kerjasama antara pelaku dan korbankasus pertikaian artis untuk mendapatkan ketenaran.

2. Hubungan antara Korban dan pelaku dapat dilihat dari tingkat 
kesalahannya

Yang sama sekali tidak bersalah— kecelakaan

Yang jadi korban karena kelalaian — pencurian

Yang sama salahnya dengan pelaku — pembunuhan

Yang lebih bersalah dari pelaku - pembunuhan terhadap penjahat

3. Hubungan darah — teman dekat - sahabat-pacar-rekan bisnis

4. Sasaran tindakan pelaku

Korban langsung — sasaran dari pelaku

Korban tidak langsung — pembunuhan terhadap ayah, yang menyebabkan penderitaan anak dan ibu

Menurut Romli Atmakusuma bahwa korban dan pelaku adalah setali tiga uang, siapa pelaku dan korbannya menjadi satu. Hubungan Korban dengan Peradilan Pidana;

1. Korban sebagai korban - mempunyai hak sesuai dengan UU no 13 tahun 2006

2. Korban sebagai saksi

3. Korban sebagai tersangka atau terdakwa

Oleh karena korban ini sangat rentan dengan pelanggaran hukum yang dapat dilakukan oleh semua pihak, maka perlu adanya perlindungan terhadap korban kejahatan

\section{Pemenjaraan}

Alasan pembangunan penjara tidak bisa dipisahkan dari keberadaan hukuman bagi pelaku pelanggaran hukum pidana, yakni pemenjaraan atau kurungan. Ada pendapat yang mengatakan dukungan terhadap pembangunan penjara ini adalah; bila kejahatan meningkat, maka kita perlu membangun lebih banyak penjara untuk menampung lebih banyak penjahat; dan bila kejahatan menurun, kita perlu membangun penjara yang lebih banyak lagi. Dengan pembangunan banyak penjara, maka akan menekan angka kriminalitas". 


\section{VIKTIMOLOGI DAN PEMENJARAAN}

Pada awal mulanya ada hukuman pemenjaraan, penjara dibuat sedemikian rupa, yakni berupa batu bata, ada aliran listrik, bawah tanah, tertutup dari dunia luar bahkan antara satu dengan yang lain, tidak bisa saling melihat. Pelaku tindak kejahatan yang sama, belum tentu mendapatkan hukuman yang sama yaitu bias hakim dalam memutuskan perkara - pemutus perkara pidana tergantung kepada hakim.

\section{Bentuk-bentuk Pemenjaraan}

\section{Rutan (rumah tahanan)}

Untuk mengurung tersangka dalam jangka pendek yang beroperasi di wilayah provinsi setempat. Yang dikenakan kepada pelaku kejahatan dalam jangka pendek, kurang 1 tahun, pelaku kejahatan tindak pidana ringan (tipiring). Rumah tahanan ini juga berfungsi untuk mengamankan terdakwa yang mendapat ancaman dari pihak luar, terdakwa yang berpotensi bahaya yang ditahan sebelum dan selama masa persidangan untuk mencegah agar tidak melarikan diri dari pengadilan.

\section{Penjara.}

Untuk mengurung penjahat yang dinyatakan bersalah untuk jangka waktu yang lama- puluhan tahun, ada yang dibebaskan kembali ke masyarakat, akan tetapi ada yang dihukum sampai mati.

\section{Istilah lain dari penjara;}

1. Penal Institution - lembaga penghukuman

2. Penitentiary - penjara mempunyai akar religious dan merujuk pada tempat dimana seseorang dapat bertobat dan menebus dosadosanya

3. Correctional institution - lembaga pemasyarakatan- tempat dimana perilaku kejahatan dapat diperbaiki 


\section{Tujuan Pemenjaraan;}

1. Inkapasitasi- pengurungan - jika penjahat ini dikurung maka masyarakat akan terselamatkan dan penjahat tersebut kehilangan kapasitasnya untuk merugikan orang lain.

2. Deterrence - pencegahan - pengalaman menderita dipenjara diharapkan mampu memberikan efek jera sehingga ketika kembali kepada masyarakat tidak melakukan tindak kejahatan lagi

3. Retribution - retribusi atau ganti rugi - masyarakat beranggapan bahwa penjara adalah setimpal dengan tindak kejahatan yang dilakukan oleh penjahat, sehingga dia bisa merasakan bahwa tindakan yang dilakukannya menyakitkan pihak lain. Retribusi ini sangat back for looking - melihat ke belakang, dalam arti tujuan ini difokuskan pada tindak kriminalnya.

4. Rehabilitasi - tujuan ini sangat forward looking, yaitu melihat ke depan, bahwa nantinya penjahat akan dikembalikan kepada masyarakat, sehingga perlu dipulihkan kondisinya dipenjara agar jika kembali ke masyarakat bisa beradaptasi di masnyarakat dengan baik.

Tujuan rehabilitasi ini sesuai dengan apa yang disampaikan Plato; bahwa tujuan pemenjaraan atau hukuman adalah berlipat dua - orang yang tepat untuk dijatuhi hukuman mestinya menjadi lebih baik atau mendapatkan manfaat dari hukumannya tersebut atau menjadikan dirinya contoh bagi sesamanya agar dapat melihat apa yang diderita dan takut mengalami penderitaan yang sama, sehingga menjadi orang yang lebih baik (Constanzo, 2006:440)

\section{Budaya Penjara yang Khas}

Kondisi penjara merupakan sub kultur yang memiliki aturanaturan, norma-norma, hierarki kekuasaan, penghargaan dan hukumannya sendiri. Narapidana yang pada awalnya memasuki penjara akan mengalami prisonization-asimilasi narapidana baru ke dalam norma-nilai dan bahasa penjara. Selain itu ada 


\section{VIKTIMOLOGI DAN PEMENJARAAN}

budaya baru yang diimpor dari luar, yakni kekerasan. Mengingat para penghuni penjara adalah banyak orang jalanan yang memiliki budaya kekerasan. Sehingga dua proses yang dialami di dalam penjara adalah prisonization dan impor budaya kekerasan. Kondisi ini yang melahirkan kebudayaan yang brutal. Pada situasi ini ada tindakan yang diambil oleh narapidana;

1. Mengekang diri, narapidana menjauhkan diri dari kebudayaan tersebut, menyelesaikan hukumannya dan segera meninggalkan penjara

2. Menganggap dirinya sebagai convicts (orang hukuman) yang tidak memiliki harapan untuk menjalani kehidupan produktif di luar, sehingga ikut meleburkan diri dalam kebudayaan yang tumbuh dalam penjara

Penghargaan dan hukuman dipenjara bisa datang dari petugas penjara atau dari narapidana yang lain. Realitas keras dalam kehidupan penjara;

1. Narapidana dipisahkan dari dunia luar

2. Narapidana tidak memiliki kekuasaan untuk memutuskan aspek-aspek pentimg kehidupannya

3. Lingkungan fisik penjara yang kejam dan opresif

4. Kehilangan privasi

5. Ada ancaman yang datang dari luar; penjaga atau napi yang lain

6. Ada banyak waktu kosong dan rutinitas yang dipaksakan

\section{Kekerasan dan Ancaman Kekerasan}

Penjara memiliki iklim kekerasan yang tidak ada bandingnya di dunia bebas. Penjara adalah sekolah para gladiator. Narapidana diteror oleh sesama napi selama bertahun-tahun dan harus hidup dalam kesakitan atau pun narapidana diteror oleh penjaga. Adanya perkosaan sesama jenis. orang yang paling dihormati adalah mereka yang pernah membunuh orang lain, terutama sesama narapidana. Adanya fenomena geng dan fenomena narkoba. 
Berhasilkah Pemenjaraan? pertanyaan tersebut sering muncul dalam benak kita, ketika melihat fakta-fakta proses penyimpangan yang terjadi di dalam penjara. Beberapa permasalahan umum yang muncul terkait dengan pemenjaraan ini, yaitu:

1. Pemenjaraan memerlukan biaya yang sangat mahal—karena menghidupi napi selama dalam pemenjaraan

2. Terjadinya penularan penyakit, membiayai manula yang mahal

3. Penjara melaksanakan tugas mengurung penjahat dengan luar biasa baik

4. Dilihat dari retribusi, penjara sukses besar-kehilangan otonomi/kekuasaan/privasi, orang-orang tercinta, kehilangan kesempatan.

Bila diukur dari rehabilitasi, penjara dapat dikatakan gagal, karena banyak narapidana yang dibebaskan kemudian terkena skandal kejahatan kembali. Tujuan pemberian keterampilan di penjara yaitu: mengoreksi defisit pendidikan dan keterampilan kerja; mengubah sikap dan perilaku kriminal; memperbaiki kesadaran diri; meningkatkan keterampilan hubungan interpersonal; mengurangi ketergantungan narkoba; mengurangi kontak sesama penjahat.

\section{Alternatif di luar Pemenjaraan;}

1. Probasi-pembebasan bersyarat- menangguhkan penahanan dan melepaskan pelaku kejahatan ke masyarakat dibawah pengawasan petugas

2. House arrest—penahanan rumah

3. Shock incarceration-pengurungan kejutan-menempatkan pelaku kejahatan yang masih muda dalam jangka pendek

4. Halfway house - tempat berupa rumah yang diigunakan untuk pelaku kejahatan tertentu

\section{Tujuan Alternatif pemenjaraan yaitu :}

1. Lebih murah dibandingkan pemenjaraan

2. Penjara itu terlalu berat dan tidak membuat jera; 


\section{VIKTIMOLOGI DAN PEMENJARAAN}

3. Pemborosan dalam pemeliharaan penjara;

4. Alternatif bagi pelaku kejahatan ringan, baru pertama melakukan tindak kejahatan dan masih muda 
BAB X

Kasus-kasus dalam

Perspektif Hukum

dan Kriminal 


\section{Kekerasan dalam Rumah Tangga (KDRT)}

\section{Kondisi Sosial Ekonomi dan Politik Perempuan}

Bagaimana kondisi perempuan, ditinjau dari sosial, ekonomi dan politik tidak jauh berbeda dengan kondisi sosial, ekonomi dan politik yang berkembang di suatu negara. Ideologi yang menjadi arus mainstream di sebuah negara menentukan bagaimana perempuan diperlakukan di negara tersebut.

Feodalisme yang menempatkan dominasi kepada pemilik lahan, dalam hal ini kaum laki-laki, sementara perempuan hanya sebagai obyek dari kekuasaan dominan tersebut. Maka istilah yang muncul, wanitasebagai sebutan perempuanyangartinya wani ditoto. Perempuan adalah pelengkap laki-laki yang mempunyai pekerjaan seputar dapur, sumur dan kasur. Film Pride and Prejudice menggambarkan situasi Feodal, pada abad ke-18 di Eropa. Posisi perempuan benar-benar sebagai pelengkap laki-laki. Bagaimana kehidupannya dari masa kecil sampai dengan dewasa hanya diperuntukan untuk bagaimana mendapatkan simpati, perhatian dan cinta dari laki-laki. Tentunya laki-laki yang diidamkan pun tidak hanya sebatas laki-laki "biasa" saja tetapi yang mempunyai nilai lebih; harta, tahta dan kedudukan (kekuasaan). Perempuan sangat mengidamkan laki-laki tampan, gagah, mapan dan mampu melindungi perempuan, sehingga yang dipilih misalnya; pengusaha, militer dan bangsawan. Perempuan tidak bisa memilih dan kehidupan yang "merdeka'. Tetapi menunggu 
dipilih dan memiliki ketergantungan yang tinggi pada pihak yang dianggapnya memiliki dominasi terhadapnya, orang tua dan kerabat. Kondisi ini merupakan gambaran masih lekatnya budaya patriarki pada karakter masyarakat Feodal. Pada situasi ini kekerasan terhadap perempuan menjadi sebuah hal yang dianggap biasa dan seharusnya atas nama "kesetiaan, cinta kasih dan kodrat" seorang perempuan.

Bergeser pada masyarakat industri ada perubahan terhadap perlakuan kepada perempuan. Pada awalnya perempuan lebih banyak di rumah dengan aktivitas domestik, pada masa ini perempuan didorong untuk keluar dari pekerjaan domestik dan beraktivitas pada ranah publik. Tuntutan industri yang membutuhkan tenaga kerja massal dan murah jatuh pada perempuan. Mereka didorong untuk menempati pos-pos pekerjaan publik sebagai salah satu bentuk upaya partisipasi dan kesetaraan perempuan terhadap akses pekerjaan. Selain sektor pekerjaan, perempuan pada masa ini pun juga mendapatkan kemudahan dalam mengenyam pendidikan karena pendidikan dan pekerjaan tidak bisa dipisahkan. Untuk mendapatkan pekerjaan "layak" tentunya memerlukan pendidikan yang tinggi pula, begitu pun sebaliknya. Akan tetapi yang menjadi persoalan dan memunculkan tindak kekerasan, walaupun perempuan didorong untuk bekerja pada ranah publik, akan tetapi terdapat konstruksi sosial dan budaya yang mengkondisikan perempuan bertanggungjawab terhadap pekerjaan domestik. Inilah yang disebut dengan double bourden (beban kerja ganda). Kondisi ini yang memungkinkan perempuan dan laki-laki yang pada posisi setara sangat rentan dengan "kekerasan" yang dilakukan oleh kedua belah pihak. Pelaku bisa dari pihak perempuan ataupun laki-laki, korban pun sebaliknya bisa laki-laki dan perempuan.

Jika demikian yang menjadi permasalahan adalah bukan jenis kelaminnya laki-laki ataupun perempuan, tetapi lebih pada perilaku kekerasan yang muncul dari pihak yang mendominasi terhadap yang lain, bisa laki-laki ataupun perempuan. Artinya kesetaraan dan partisipasi ini tidak mengenal jenis kelamin, akan tetapi lebih 
pada budaya saling menghargai dan "menganggap ada" kelompokkelompok marginal, bukan sebagai sampah masyarakat.

\section{Perempuan dan Islam}

Posisi perempuan dalam Islam memang dibedakan dengan lakilaki, akan tetapi perbedaan tersebut seharusnya bukanlah sebagai pembeda yang menguntungkan satu pihak dan merugikan pihak yang lain. Akan tetapi justru mendukung misi pokok Al Qur'an yakni terciptanya hubungan harmonis yang didasari kasih sayang (mawaddahwa rahmah) di lingkungan keluargayang nantinya menjadi pendukung terwujudnya suatu negara yang penuh ampunan dari Allah (baldatun thayyibatun wa rabbun ghafur). Kesamaan tersebut dapat dilihat pada: (1) hakikat kemanusiaannya. Islam memberikan sejumlah hak kepada perempuan untuk peningkatan kualitas kemanusiaannya. Hak tersebut antara lain; waris (An.Nisa/4:11), persaksian (Al Baqarah/2:282), aqiqah (At Taubah/ 9:21); (2) Islam mengajarkan bahwa laki-laki dan perempuan mendapat pahala yang sama atas amal sholeh yang dibuatnya, sebaliknya keduanya mendapatkan azab yang sama atas pelanggarannya; dan (3) Islam tidak mentolerir adanya perbedaan dan perlakuan tidak adil antar umat manusia (Al Hujurat/49:13). Pada ayat tersebut menunjukan bahwa laki-laki dan perempuan diperlakukan sama walaupun berasal dari bangsa dan suku yang berlainan (Musdah, 2001).

Rasulullah pun sebagai nabi juga sangat memberikan contoh dalam membangun kesetaraan relasi antara laki-laki dan perempuan ini. Dalam kehidupan sehari-hari, Beliau mengerjakan pekerjaan rumah tangga; mencuci, membersihkan rumah, memeras susu kambing dan sebagainya. Dalam hal partisipasi, istri-istri Beliau diberikan kebebasan untuk berpendapat dan lebih berperan dalam kehidupan publik (pencari nafkah utama).

Sementara itu, beberapa ayat Al Qur'an yang menafsirkan bahwa laki-laki adalah pemimpin bagi perempuan (An Nisa), beberapa Ulama melakukan tafsir ulang bahwa pada konteks tersebut, 
hubungan laki-laki dan perempuan lebih pada hubungan yang bersifat bekerjasama satu sama lain (partner kerja). Sementara itu tentang adanya Hadis dari Abu Hurairah RA, yang menyebutkan bahwa perempuan yang tercipta dari tulang rusuk yang bengkok, jika kau paksa meluruskannya dia akan patah, dan jika kau biarkan tentu dia akan tetap bengkok. Mengenai tafsir dari hadist tersebut perlu dibaca dengan kritis, bahwa ada ayat-ayat lain yang berbicara tentang penciptaan antara laki-laki dan perempuan bahwa perempuan diciptakan terlebih dahulu dibandingkan dengan laki-laki. Al Qur'an yang menjelaskan relasi tersebut adalah sebagai berikut; Q.S 4:1; 7:189 dan 39:6. Hal ini menunjukan bahwa hubungan antara laki-laki dan perempuan adalah saling melengkapi satu sama lainnya (Musdah, 2001).

\section{Kekerasan terhadap Perempuan}

Ajaran Islam sebagai rahmatan lil 'alamin pun secara tekstual memberikan ruang yang sama terhadap peran antara laki-laki dan perempuan tersebut. Akan tetapi ada kata yang selalu kita ingat sebagai seorang sosiolog yang selalu membaca fakta di masyarakat bahwa fakta yang muncul di lapangan, tidak selalu sama dengan apa yang tertulis. Pada kenyataannya indahnya kesetaraan antara laki-laki dan perempuan dalam kitab suci tersebut, umat Islam pun banyak yang tidak menerjemahkan tekstual tersebut dalam kehidupan sehari-hari. Kesetaraan dan saling melengkapi satu sama lain pun belum bisa terwujud, bahkan yang muncul adalah diskriminasi sosial yang berbasiskan perbedaan jenis kelamin antara laki-laki dan perempuan. Diskriminasi ada karena adanya perbedaan antara jenis kelamin yang satu terhadap yang lain, dalam arti ada satu jenis kelamin yang tertinggal dibandingkan lainnya. Diskriminasi sosial tersebut berbentuk; stereotype, subordinasi, marjinalisasi, kekerasan dan beban ganda (Faqih, 1998). Berkaitan dengan kekerasan yang dialami oleh perempuan ini menurut UU No. 24 tahun 2004 tentang UU PKDRT kekerasan dikategorikan menjadi; kekerasan 
ekonomi, fisik, psikis dan seksual. Berdasarkan data Rifka Annisa, kasus kekerasan yang menimpa perempuan tersebut adalah sebagai berikut:

Tabel.6 Data Kasus KDRT

\begin{tabular}{|l|l|l|}
\hline \multirow{5}{*}{ Data KDRT menurut Rifka Annisa } & 2003 & 335 \\
\cline { 2 - 3 } & 2004 & 349 \\
\cline { 2 - 3 } & 2005 & 312 \\
\cline { 2 - 3 } & 2006 & 269 \\
\cline { 2 - 3 } & 2007 & 329 \\
\cline { 2 - 3 } & 2008 & 309 \\
\hline \multirow{5}{*}{ Perempuan } & 2000 & 232 \\
\cline { 2 - 3 } & 2001 & 258 \\
\cline { 2 - 3 } & 2002 & 111 \\
\cline { 2 - 3 } & 2004 & 329 \\
\cline { 2 - 3 } & 2005 & 455 \\
\cline { 2 - 3 } & 2006 & 323 \\
\cline { 2 - 3 } & 2007 & 283 \\
\cline { 2 - 3 } & 2008 & 275 \\
\hline
\end{tabular}

Sumber: Data KDRT menurut Rifka Annisa dan Mitra Perempuan, 2020

\section{Undang-Undang PKDRT}

Tahun 2004 merupakan momen yang sangat penting bagi gerakan perempuan di Indonesia. Mengingat pada tahun tersebut undang-undang yang memberikan perlindungan kepada perempuan disetujui dan menjadi affirmative action terhadap setiap kekerasan yang menimpa perempuan selama ini. Banyak pihak yang tidak menyetujui dan mencibir kelahiran Undang-undang tersebut, disebut sebagai undang-undang yang bersifat "lelucon" dengan mengatakan "relasi suami istri dalam rumah tangga diatur oleh orang lain”. Itu merupakan permasalahan yang privat dan negara tidak 
perlu mengatur urusan privat sebuah rumah tangga.

Tentu tidak mudah mengubah apa yang menjadi stereotype masyarakat tentang relasi antara perempuan dan laki-laki dalam konteks domestik (pekerjaan rumah tangga). Perlu kerjasama dengan berbagai pihak, tidak hanaya gerakan perempuan itu sendiri akan tetapi perlu bersinergi dengan gerakan sosial yang lain. Gerakan perempuan di Indonesia tumbuh dan berkembang sesuai dengan perkembangan gerakan perempuan di tingkat Internasional. Pada masa Orde lama, Gerakan Wanita Indonesia (Gerwani) mampu menunjukan aktivitas sebagai sebuah organisasi perempuan yang mampu sejajar dengan organisasi yang lain. Perempuan pada masa itu sudah mendapatkan hak sosial, ekonomi dan politik dari negara. Akan tetapi pergolakan politik pada masa itu menyebabkan organisasi dibubarkan sampai pada level yang paling rendah.

Pada masa Orde Baru, organisasi perempuan direduksi dan dibuat seragam dari tingkat nasional sampai daerah dengan nama Dharma Wanita dengan kegiatannya yang paling familiar adalah PKK (Pendidikan Kesejahteraan Keluarga). Pada waktu itu kegiatan PKK ini justru mendomestifikasi peranan perempuan. Artinya perempuan lebih banyak disibukan dengan aktivitas domestik dibandingkan dengan kegiatan publik, dengan tujuan untuk meningatkan peran serta perempuan sebagai pendukung keharmonisan keluarga dan masyarakat. Walaupun pada situasi sedemikian rupa, gerakan perempuan justru mampu membangun kekuatan untuk memperjuangkan hak-hak ekonomi, politik, sosial dan budaya dengan berbagai macam aktivitas yang bersifat non formal. Tentunya yang mempelopori aktivitas tersebut adalah akademisi yang melahirkan gerakan sosial berbasiskan perempuan dalam wadah Non Government Organisation (NGO), LSM ataupun organisasi lain yang bersifat massal. Pasca reformasi semua aktivitas perempuan tersebut menemukan momentum sampai pada tahap perjuangan litigasi, terutama dengan lahirnya UU PKDRT dan adanya kuota 30\% untuk perempuan di DPR. Kedua perangkat 
hukum tersebut memberikan angin pada aktivitas kaum perempuan di domestik dan publik. Setiap kekerasan yang terjadi pada level domestik ada perlindungan hukum bagi kaum perempuan. Demikian pula pada ranah publik, perempuan mendapatkan kesempatan yang sama untuk bisa berkiprah di dunia politik sama dengan kaum lakilaki, dimana selama ini dunia politik banyak didominasi laki-laki.

\section{Perspektif Sosiologi Hukum}

Pada masa sekarang ini, sudah hampir 6 tahun berlakunya UU PKDRT dan kuota 30\% untuk perempuan. Harapannya dengan lahirnya payung hukum bagi perempuan tersebut, semakin berkurangnya kasus kekerasan perempuan dalam rumah tangga dan partisipasi aktif perempuan pada dunia politik semakin tinggi dibandingkan dengan tahun sebelumnya. Payung hukum itupun diiringi dengan berbagai macam kegiatan yang bersifat edukatif bagi masyarakat dan penyadaran bagi perempuan itu sendiri tentang hakhaknya, untuk menyangga dan menguatkan masyarakat terhadap keberadaan perlindungan hukum bagi perempuan. Sebagai sarana sosialisasi dan pendidikan politik bagi masyarakat. Pemerintah dan organisasi non pemerintah pun terlibat aktif dalam upaya tersebut, dengan berbagai macam bentuk program pendidikan dan pemberdayaan perempuan.

Upaya ini secara umum dinilai berhasil, masyarakat sudah familiar dengan permasalahan perempuan. Sebutan perempuan sudah tidak asing di masyarakat. Sebelum familiar dengan perempuan, istilah yang digunakan adalah wanita yang dalam terminologi Jawa sebagai kependekan dari wani ditoto (perempuan adalah orang yang mudah ditata (diatur) oleh laki-laki sebagai kaum yang dominan). Perempuan sendiri adalah seseorang yang diempu(akar)kan. Artinya memiliki kekuatan sebagai ujung tombak dari keberhasilan keluarga dan negara. Perempuan diposisikan sebagai makhluk yang terhormat dan sejajar dengan laki-laki. 
Selain penyebutan istilah perempuan, pada dunia kerja pada beberapa jabatan tertentu di setiap level mulai ada kebijakan yang tidak bias gender. Dalam arti adanya pelibatan perempuan dalam setiap aktivitas atau program kegiatan dan menduduki berbagai macam jenis pekerjaan. Situasi ini memposisikan perempuan untuk lebih berperan aktif dalam aktivitas publik dan tidak hanya tersita pada aktivitas domestik. Lagi-lagi perempuan mempunyai kesempatan yang sama dalam pekerjaan publik dengan laki-laki. Tidak ada perbedaan partisipasi perempuan dan laki-laki pada berbagai jenis pekerjaan yang melibatkan laki-laki dan perempuan. Perempuan bisa menjadi tukang parkir, tambal ban ataupun angkat besi serta menikmati fasilitas yang dulunya tabu dilakukan. Naik motor laki-laki ataupun bekerja di pertambangan sudah biasa perempuan lakukan.

Kesempatan partisipasi yang sama dalam berbagai jenis pekerjaan serta payung hukum untuk perlindungan hukum bagi perempuan adalah termasuk afirmative action untuk mencegah terjadinya berbagai macam kekerasan; psikis, fisik, ekonomi ataupun seksual. Pada kenyataannya pasca diberlakukannya UU PKDRT tersebut angka kekerasan terhadap perempuan, cenderung meningkat (lihat tabel angka kekerasan). Bahkan bisa jadi lebih tinggi karena banyak kasus kekerasan yang terjadi di masyarakat dibiarkan saja dan tidak disampaikan kepada pihak luar (pemerintah atau lembaga bantuan hukum). Mengingat kekerasan dalam rumah tangga merupakan delik aduan, artinya kalau korban tidak melaporkan, suatu kasus tidak bisa diproses.

Pasca pemberlakuan payung hukum tersebut, kekerasan tidak hanya dilakukan oleh laki-laki akan tetapi oleh perempuan sendiri kerap terjadi. Perempuan menjadi pelaku kekerasan. Yang sangat nampak adalah relasi PRT dengan pengguna jasa (majikan) yang mayoritas lebih dekat dengan perempuan. Banyak kekerasan terhadap PRT dilakukan oleh majikan perempuan daripada majikan laki-laki. Perempuan kelas atas menindas perempuan kelas bawah 
pada situasi ini. Termasuk kekerasan istri terhadap suami di rumah tangga. Fenomena yang lain, laki-laki pun juga semakin banyak yang melakukan kekerasan, ketika istrinya memiliki "kelebihan" dari segi ekonomi, politik ataupun status sosial. Watak feodalisme dengan budaya patriarki muncul ketika relasi antara suami dan istri di luar kondisi yang seharusnya berlaku dalam masyarakat, laki-laki lebih mendominasi perempuan.

Masyarakat Indonesia pada transisi feodalisme ke modern secara revolusi masih menyisakan kultur yang feodal. Pada kelas tertentu memang pendidikan gender dan sosialisasi UU PKDRT dapat terjangkau, akan tetapi pada kelas lain yang berjumlah mayoritas justru tidak mengetahui apa itu gender dan KDRT. Kebiasaan mendominasi dan melakukan kekerasan menjadi sebuah "tradisi" sampai subyek pelaku maupun korban tidak mengetahui bahwa apa yang mereka lakukan disebut kekerasan. Kekuatan yang bersifat hegemonik masih mengungkung setiap tindakan masyarakat. Arus modern yang serba cepat dengan membawa angin keseteraan baru merubah ide dan wacana relasi antara kelas dominan dan terdominasi bahkan pada situasi tertentu semakin terpolarisasi jarak diantara keduanya. Pendekatan law enforcement pun belum mampu merubahnya.

Pasal-pasal dalam UU PKDRT yang mendefinisikan kekerasan, ancaman hukuman dan denda yang harus dibayarkan pelaku pada korban hanya menjadi praktek pejabat hukum dan tidak diterjemahkan oleh masyarakat. Tidak banyak kasus kekerasan dalam rumah tangga yang bisa diangkat sampai ke pengadilan, kecuali untuk beberapa masyarakat yang mempolitisirnya atau membuat sensasi. Mengangkat kasus kekerasan dalam rumah tangga pada ranah hukum adalah "tabu" bagi mayoritas masyarakat. Ada ketakutan, rasa malu, keengganan ataupun tidak mampu membayar perkara sampai ke pengadilan menjadikan mayoritas masyarakat memilih diam dengan apa yang terjadi. Apalagi citra pejabat hukum ataupun lembaga peradilan adalah sangat buruk dengan berbagai macam kasus suap dan korupsi. 
Tahap diberlakukannya UU PKDRT baru satu langkah untuk menyelesaikan kekerasan terhadap perempuan. Mengingat sampai pada tahap ini perubahan di dalam masyarakat belum nampak secara progresif. Pada situasi tertentu, masih ada kebijakan yang bias gender. Bahkan kebijakan yang dianggap peka gender pun justru semakin memperlemah posisi perempuan itu sendiri. Kuota $30 \%$ bagi perempuan di parlemen adalah afirmative action, akan tetapi ada sebagian berpendapat justru semakin menunjukan posisi perempuan yang "lemah" sehingga memerlukan jatah kursi untuk mempengaruhi kebijakan. Kalau perempuan itu setara kemampuan dan kecerdasannya dengan laki-laki tanpa mendapatkan jatah pun pasti akan bisa menjadi anggota parlemen.

Penegakan hukum yang tidak dilakukan secara progresif perlu ditindaklanjuti dengan langkah berikutnya, pendekatan sosial budaya untuk membersihkan sisa feodalisme. Sosialisasi dan pendidikan gender secara masif harus menjadi konsumsi semua kelas dalam masyarakat. Yang lebih penting lagi selalu menekankan bahwa penghapusan kekerasan tersebut bukanlah antar jenis kelamin lakilaki dan perempuan. Pengertiannya lebih luas, yakni relasi antara masyarakat yang dominan dan terdominasi. Kesadaran kelas untuk lebih memanusiakan masyarakat lain yang tertindas sosial, ekonomi dan politik adalah paling penting. Sehingga permasalahan kekerasan bukanlah laki-laki adalah musuh perempuan dan sebaliknya. Akan tetapi lebih pada perlawanan kelas yang terdominasi terhadap yang mendominasi. Kesadaran yang tidak bias jenis kelaminnya tersebut, akan menumbuhkan penghargaan dan saling menghormati kaum yang berbeda jenis kelamin. Itulah hakikat pelaksanaan UU PKDRT secara progresif. Tanpa UU tersebut pun seharusnya kita sudah menghapuskan kekerasan terhadap perempuan, karena dalam diri kita sudah tertanam untuk menempatkan kaum tertindas setara dengan kita. Tanpa diskriminasi dan penindasan. 


\section{Pelibatan Anak Pada Aktivitas Politik}

\section{Pengertian dan Hak Anak}

Ketika kita menyebut kata anak, maka ada berbagai macam gambaran yang ada di kepala kita. Kelucuan, keluguan, kecerdasan, kelemahan, bahkan kekerasan tergambar pada wajah anak-anak ini. Menurut UU No. 23/2002 tentang Perlindungan Anak menyebutkan bahwa anak adalah seseorang yang berusia 18 tahun, termasuk anak yang masih ada dalam kandungan. Dalam bayangan kita, gambaran tentang anak yang sedemikian rupa menunjukan bahwa anak membutuhkan hal-hal tambahan khusus dibandingkan dengan orang dewasa. Anak-anak ini memerlukan tambahan bentuk perhatian karena mereka masih terus tumbuh dan mereka ini memiliki tubuh yang kecil, biasanya mereka juga belum memiliki pengalaman dan mengenyam asam garam kehidupan, mereka tidak memiliki tenaga sekuat orang dewasa.

Anak sebagai warga negara ditambah dengan kondisi anak yang sedemikian rupa, sehingga ada hak-hak yang perlu mendapatkan perlindungan dari berbagai pihak dan diatur dalam UU No. 23/2002. Adapun secara umum hak-hak dasar anak tersebut adalah; hak atas kelangsungan hidup, hak untuk berkembang, hak atas perlindungan dan hak berpartisipasi dalam kehidupan bermasyarakat. Kelangsungan hidup dan berkembang tersebut berkaitan dengan keharusan tahu seorang anak terhadap status warga negaranya, beribadah menurut agamanya, berpikir dan berekspresi sesuai dengan tingkat kecerdasannya dan usianya sesuai dengan bimbingan orang tua, mengetahui dan diasuh oleh orang tuanya, memperoleh pelayanan dan jaminan kesehatan, memperoleh pendidikan dan pengajaran sesuai dengan tingkat kecerdasannya, didengar pendapatnya serta memanfaatkan waktu luangnya. Sedangkan perlindungan yang seharusnya diterima oleh anak adalah perlindungan dari perlakuan diskriminasi, eksploitasi, penelantaran, kekerasan dan ketidakadilan. Dengan bentuk-bentuknya antara lain; penyalahgunaan dalam kegiatan politik, pelibatan dalam sengketa senjata, kerusuhan sosial, peperangan dan peristiwa yang mengandung unsur kekerasan. 
Sementara itu bentuk partisipasi anak dalam bentuk anak sebagai subyek dalam pelaksanaan hak dan bahwa pendapat mereka harus dipertimbangkan dalam semua keputusan yang diambil atas nama mereka meskipun di dalam KHA (Konvensi Hak Anak) juga disebutkan bahwa anak-anak memiliki keterampilan dan pemahaman yang beragam seiring dengan pertumbuhan usia dan pengalaman hidup mereka masing-masing yang berbeda satu sama lain. Berkaitan dengan partisipasi anak ini, orang tua berkewajiban; memperhatikan pendapat anak, membantu anak mengekspresikan pendapat mereka, mempertimbangkan dengan sungguh-sungguh pendapat mereka, menilai baik-buruknya pendapat anak-anak tersebut sesuai dengan usia dan kematangan anak-anak, membuat keputusan bersama anakanak dan memastikan bahwa anak-anak mengerti (Regional Working Group on Child Labour, 2002).

Pengaturan tentang hak-hak anak dalam UUPA tersebut mendapatkan porsi yang lebih besar dibandingkan dengan kewajiban anak yang hanya dicantumkan dalam satu pasal saja. Bahwa kewajiban anak adalah; menghormati orang tua, wali dan guru; mencintai keluarga, masyarakat dan menyayangi teman; mencintai tanah air, bangsa dan negara, menunaikan ibadah sesuai dengan ajaran agamanya dan melaksanakan etika dan akhlak yang mulia. Ini menunjukan bahwa anak pada posisi yang "lemah" dan membutuhkan perlindungan dari berbagai pihak. Pihak-pihak yang seharusnya memberikan perlindungan kepada anak ini adalah sebagai berikut:

Pemerintah Desa

Masyarakat

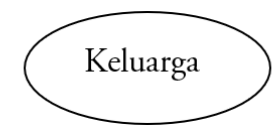

Pemerintah Daerah dan Pusat

Pemerintah Internasional 
Berlakunya UU No. 23/2002 sebagai bagian dari ratifikasi Konvensi mengenai hak-hak Anak (Convention on the Rights of the Child/CRC) yang menegaskan bahwa anak-anak mempunyai hak yang sama dengan orang dewasa dan juga mencantumkan hak-hak khusus yang dimiliki semua orang yang berusia dibawah 18 ; jaminan atas pertumbuhan dan perkembangan anak melalui pelayanan kesehatan dan pendidikan, perlindungan anak terhadap eksploitasi dan kekerasan serta keikutsertaan anak dalam keputusan yang diambil atas nama mereka. Cara penafsiran hak-hak ini tergantung pada usia dan kematangan anak-anak, tetapi satu prinsip terpentingnya adalah bahwa orang-orang dewasa harus mengutamakan "yang terbaik" (kesejahteraan sebesar-besarnya) bagi seorang anak atau sekelompok anak sebelum melihat kepentingan mereka sendiri. Hal ini sama artinya dengan sedapat mungkin mempertimbangkan pendapat anak.

\section{Pengertian Politik}

Apabila kita mendengar kata politik, tentu yang tergambar adalah pengertian yang berbeda dengan apa yang kita bayangkan tentang dunia anak ataupun hak-hak anak yang seharusnya mendapatkan perlindungan. Politik mempunyai bermacam-macam definisi. Pada umumnya politik adalah bermacam-macam kegiatan dalam suatu sistem politik atau negara yang menyangkut proses menentukan tujuan-tujuan dari sebuah sistem dan melaksanakan tujuan-tujuannya. Untuk melaksanakan tujuan-tujuan tersebut ditentukan oleh adanya kebijakan-kebijakan umum (public policies) yang menyangkut pengaturan dan pembagian (distribution) atau alokasi (allocation) dari sumber-sumber (resources) yang ada. Sedangkan untuk melaksanakan kebijakan-kebijakan tersebut diperlukan kekuasaan (power) dan kewenangan (authority) yang digunakan untuk membina kerjasama dan menyelesaikan konflik yang timbul dalam proses ini. Dengan cara persuasi (meyakinkan) ataupun paksaan (coersion). Politik juga menyangkut tujuan-tujuan dari seluruh masyarakat dan bukan untuk tujuan pribadi seseorang (Miriam, 1993). 
Pengertian politik direduksi lebih sempit dengan kegiatan-kegiatan yang bersifat pragmatis, dalam bentuk pemilihan umum (pemilu) sebagai bagain dari demokrasi. Dimana secara sederhana demokrasi diartikan dari asal katanya, yakni; demos adalah pemerintahan dan krateos diartikan rakyat, sehingga demokrasi adalah pemerintahan rakyat (KBBI, 1989). Pengertian lain tentang demokrasi sangat beranekaragam, namun yang paling popular dirumuskan oleh Abraham Lincoln pada tahun 1863. Menurutnya demokrasi adalah pemerintahan dari rakyat, oleh rakyat dan untuk rakyat (government of the people, by the people, for the people). Intinya demokrasi adalah suatu tata pemerintahan dimana rakyat, baik secara langsung ataupun tidak, berkuasa dan berdaulat penuh. Dari sini demokrasi harus dilihat dari dua sisi;

1. Sisi substansial (nilai hakiki), dimana demokrasi bisa tegak kalau ada nilai-nilai atau budaya yang memungkinkan rakyat bisa memiliki kedaulatan dalam arti yang sesungguhnya. Misalnya ada kebebasan dan budaya menghormati kebebasan orang lain, adanya pluralisme dan toleransi, anti kekerasan dan sebagainya.

2. Dimensi prosedural (aturan dan tata cara), dimana demokrasi hanya bisa tegak jika ada prosedur-prosedur formal yang memungkinkan nilai dan budaya demokrasi itu ada dan berjalan. Pemilihan umum yang bebas, adanya DPR yang kuat, lembaga yudikatif yang independen adalah termasuk bagian dari aspek prosedural demokrasi (Eman, 2000).

Akan tetapi sangat disayangkan kita terjebak pada kehidupan demokrasi prosedural, dimana demokrasi selalu identik dengan uang. Bahkan yang lebih parah kapital ini ibarat mesin yang menjalankan demokrasi. Kondisi ini dapat dilihat dari pelaksanaan pemilu selama periode reformasi ini; pemilihan presiden (pilpres), pemilihan kepala daerah (pilkada), ataupun pemilihan legislatif. Selalu saja ada serangan fajar menjelang hari $\mathrm{H}$ pemilihan umum, baik di level pedesaan ataupun perkotaan. 


\section{Aktivitas Anak dalam Politik}

Menganalisis bagaimana aktivitas anak dalam dunia politik, tidak bisa dipisahkan dari bagaimana aktivitas anak yang berkaitan dengan kegiatan ekonomi yang selama ini ada. Beberapa bentuk yang muncul adalah fenomena pekerja anak di banyak sektor pekerjaan. Berdasarkan Konvensi ILO, bentuk-bentuk pekerjaan yang digolongkan sebagai pekerjaan yang terburuk adalah;

1. anak-anak pekerja rumah tangga

2. anak-anak yang bekerja di sektor pertanian

3. anak-anak yang melakukan pekerjaan rumah tangga dan mengasuh anak sehingga orang tua mereka bisa keluar rumah untuk bekerja

4. anak-anak yang bekerja sebagai buruh wajib

5. anak-anak yang bekerja di bengkel-bengkel tidak resmi

6. anak-anak yang bekerja sebagai pekerja seks komersial

Sedangkan pelanggaran terhadap anak, berkaitan dengan aktivitas anak dalam pekerjaan adalah ketika anak-anak ini bekerja yang menikmati hasilnya justru lebih banyak orang tuanya dibandingkan dengan anak-anak itu sendiri. Kebutuhan orang dewasa lebih besar dibandingkan dengan kebutuhan anak.

Mempekerjakan anak dalam bentuk pekerjaan apapun ataupun pekerjaan yang terburuk bagi anak berbeda situasinya dengan mengkondisikan anak atau mendidik anak untuk berlatih bekerja. Melatih anak untuk bekerja harus diusahakan sejak usia dini, baik pekerjaan yang bersifat domestik ataupun publik. Melatih bersifat mendidik dan tidak memungut hasil dari hasil pekerjaannya tersebut, sementara mempekerjakan anak bertujuan untuk mendapatkan keuntungan ekonomi dari aktivitas yang dilakukan oleh anak tersebut. Melatih tentunya dengan pengawasan dan bimbingan dari orang tua, sedangkan bekerja tentunya tanpa pengawasan yang ketat. Justru ketika tidak melakukan pekerjaan itu, hukuman ketat yang diterima oleh anak. Membiasakan anak dengan pekerjaan rumah tangga; mencuci, membersihkan rumah, mencari rumput adalah 
bagian dari pendidikan anak untuk melatih kemandirian. Berbeda konteks dengan menyuruh anak untuk bekerja di rumah tangga orang lain dengan mendapatkan upah dan hasilnya dinikmati oleh orang tuanya, itu yang disebut mempekerjakan anak.

Sama halnya dengan pekerjaan anak pada aktivitas ataupun kegiatan politik. Pelibatan anak dalam aktivitas politik ini justru hasilnya banyak dinikmati oleh orang dewasa, dalam hal ini orang tua dan partai politik itu sendiri untuk mendapatkan dukungan massa dalam jumlah yang besar daripada kepentingan anak. Dengan tujuan untuk mendapatkan kekuasaan. Aktivitas ini terlihat pada saat kampanye partai, sosialisasi massal yang melibatkan banyak orang. Anak-anak dilibatkan untuk semakin menambah jumlah massa pendukung. Kondisi sangat berbahaya adalah ketika banyak anakanak yang ikut berkendaraan bermotor ataupun bergelantungan di truk-truk yang membahayakan keselamatannya. Dalam perpektif politik tentunya sah-sah saja. Berbeda situasinya dengan melakukan pendidikan politik anak. Aktivitas pengajaran dan bimbingan tentang kegiatan politik lebih pada pemahaman dan bimbingan tentang praktek politik tanpa harus mengikutkan mereka pada kegiatan kampanye suatu partai tertentu. Apalagi dengan praktek yang membahayakan keselamatan jiwa mereka.

Pelibatan anak dalam pekerjaan bisa dilakukan dalam konteks mendidik anak untuk bekerja dan tidak mengeksploitasi anak-anak pada satu jenis pekerjaan tertentu untuk mengharapkan hasil yang lebih dari anak. Orang tua dengan hati nuraninya tentu sangat bisa merasakan apakah pekerjaan yang dibebankan kepada anak bersifat mendidik ataukah justru menggunakan tenaganya untuk pundi-pundi rupiah. Penegakan hukum perlindungan anak, UU no.23/2002 harus mampu menyentuh pada situasi seperti ini. $\left(^{*}\right)$ 


\section{Analisis Hukum Agraria}

Dalam UU No.5 tahun 1960 tentang Peraturan Dasar PokokPokok Agraria, disebutkan bahwa yang dimaksud dengan agraria adalah bumi, air dan ruang angkasa dan segala yang terkandung di dalamnya. Permasalahan yang menyangkut penggusuran rumah TNI $\mathrm{AD}$ merupakan bagian dari permasalahan agraria, berkaitan dengan pengaturan kepemilikan lahan dan bangunan, walaupun konflik didalamnya merembet pula pada politik dan ekonomi, terutama kesejahteraan tentara kita.

Masalah agraria adalah masalah yang rumit dan menyangkut berbagai macam aspek kehidupan, sehingga perlu menggunakan pendekatan multi disiplin. Kebijakan agraria bisa dilihat dari (1) latar belakang adanya kebijakan dan (2) apa saja yang perlu dilakukan untuk menampung dampak dari pelaksanaan sutau kebijakan agraria.

Pola pembagian wilayah yang menonjol pada masa awal kerajaan di Jawa adalah berupa pembagian tanah ke dalam berbagai macam pengawasan dan penguasaan yang diberikan kepada tangan pejabatpejabat atau raja yang berwenang di istana. Pada masa itu konsep kepemilikan menurut konsep Barat (propertio, eigendom) tidak dikenal.

Pada masa itu, pemilik sawah, petani bebas atau penduduk inti sebagai keturunan dari pendiri desa membuka tanah dan menjadi elit desa yang disebut sebagai anak tani atau kulina. Sampai sekarang dikenal dengan istilah kuli kenceng atau kuli kendo.

Ketika Belanda datang ke Indonesia pada tahun 1677, ketika Mataram menjadi proterokterat VOC, maka sedikit demi sedikit pengaruh dari pejabat semakin berkurang. Abad 18, VOC mendapat kekusaan memonopoli perdagangan. VOC menjadi perantara penyerahan upeti dari pemerintah daerah ke pusat, sehingga daerah mudah sekali dipengaruhi oleh VOC untuk menancapkan kekuasaannya. Pada awal abad ke 19, VOC bangkrut dan kekuasaannya digantikan oleh pemerintah Belanda, Deandels yang 
lebih sistematis dalam pemeritahannya. Dalam persoalan agraria yang lebih detail mengaturnya adalah massa Inggris, pada saat pemerintahan Raffless.

\section{Tonggak I (1811)}

Teori Raffles yang terkenal adalah Teori Domein, yang bertujuan ingin menerapkan sistem penarikan pajak bumi seperti yang dilakukan di India. Dengan berdasarkan pengalamannya di India, maka di Indonesia dibuatlah sistem penarikan pajak bumi (yang dikenal dengan istilah Belanda landrente) dimana setiap petani diwajibkan membayar pajak sebesar 2/5 dari hasil garapannya.

\section{Tonggak 2 (1830)}

Pada masa ini Indonesia kembali kepada Balanda dan diberlakukan Cultuurstelsel (sistem tanam paksa). Terinspirasi oleh teori Raffles, Van Den Bosch membuat aturan yang hampir sama, kalau pada Landrente, setiap petani diwajibkan memberikan pajak sebesar $2 / 5$ persen, pada masa ini, petani hanya diwajibkan membayar pajak 1/5 tanahnya ditanami dengan tanaman yang dikehendaki oleh pemerintah; nila, tembakau, kopi. Pada masa ini menjadikan pemerintah Belanda sangat berlimpah.

\section{Tonggak 3 (1848)}

Para pengusaha menginginkan adanya kepemilikan tanah oleh swasta, jadi bukan hanya raja dan menteri yang bisa menikmatinya. Maka dibuatlah RUU yang mengakui hak perorangan (eigendom) dan hak sewa (erfpacht) yang ditolak oleh parlemen.

\section{Tonggak 4 (1870)}

Pada masa ini adalah tonggak agraria yang penting bagi Indonesia karena pada masa ini, diundangkan dalam lembaran negara apa yang dikenal dengan Agraris Wet. Ketentuan didalamnya dalam pelaksanaannya diatur dalam berbagai peraturan dan keputusan. Salah satu keputusan penting ialah apa yang dikenal dengan Agrarisch Besluit yang memuat pernyataan penting yang dikelan dengan 
Domein Verkliring, yang menyatakan bahwa,

"Semua tanah yang tidak terbukti bahwa atas tanah itu ada hak milik mutlak (eigendom) adalah domein negara (milik mutlak negara)."

Semenjak adanya peraturan itu, maka berduyun-duyunlah modal swasta Eropa mencengkram Indonesia. Maka muncul lah banyak sekali perkebunan-perkebunan swasta di Sumatera dan di Jawa dengan segala akibatnya. Pada masa 1870-1900, disebut sebagai zaman Liberal, yang mana para pendukung teori tersebut berharap dengan adanya kebijakan liberalisme maka terjadi transformasi pada ekonomi modern. Penataan administrasi modern di perkebunan, harapannya bisa ditiru oleh petani dalam mengolah lahannya, akan tetapi justru tidak terjadi, yang terjadi justru petani banyak yang bekerja di perkebunan Belanda dan menjadi buruh. Tujuan UU Agraria 1870 berhasil gemilang memberikan kesempatan bagi pemodal asing, tetapi tidak untuk kesejahteraan rakyat.

\section{Tonggak 5 (UUPA 1960)}

Dengan berlakunya UUPA ini seharusnya menggantikan Agraris Wet. Lahirnya UUPA ini melalui proses yang panjang; panitia Yogya (1948), Panitia Jakarta (1951), Panitia Suwahjo (1956), Rancangan Sunario (1958) dan Rancangan Sadjarwo (1960). Semangat UUPA ini adalah semangat keberpihakan kepada kepentingan rakyat, sebagaimana pernyataan berikut; gerakan rakyat adalah syarat mutlak bagi pelaksanaan hukum tanah yang baru, hukum baru itu seharusnya bukan hanya dipahami dan diterima oleh rakyat, tetapi juga harus menggegerkan jiwa rakyat. UUPA ini hanya menyusun aturan-aturan dasar yang seharusnya dijabarkan dalam peraturan yang ada didalamnya. UUPA ini lebih dikenal dengan agarian reform yang lebih luas maknanya dibandingkan land reform (Wiradi, 2001).

\section{Orde Baru}

Pada masa ini UUPA diputuskan, dengan anggapan UUPA ini adalah produk PKI, dengan TAP MPR no IV/ 1978 dan strategi 
pembangunan yang lebih mengejar stabiltas pangan dan ekonomi. Pada masa ini penerapan kebijakan agraria lebih pada kepentingan ekonomi dengan mengundang investor ke dalam negeri dengan adanya UU PMDN dan PMA. Di sektor pertanian diterapkan Revolusi Hiaju untuk mengejar swasembada pangan.

\section{Reformasi (Megawati)}

Agraria dimaknai dengan hal-hal yang bersifat sektoral, sehingga kebijakan agraria bersifat sektoral ini. Pada masa pemerintahannya lahir UU yang bersifat sektoral, misalnya; UU Air, Kehutanan, Pertambangan, dan lainnya. Hal ini mengakibatkan pemaknaan agraria menjadi sempit dan mudahnya melakukan investasi asing menanamkan modal. Salah satu perusahaan yang dapat mengeruk keuntungan besar adalah Aqua, yang menjual air sebagai akibat adanya kebijakan privatisasi air. Dengan adanya UU No.7 tahun 2004 tentang Pengelolaan Sumber Daya Air.

\section{SBY (2004-2009)}

Kebijakan Agraria, yang lebih spesifik Land Reform dimaknai dengan melakukan kegiatan yang disebut PPAN (Program Pembaruan Agraria Nasional). Dengan melakukan sertifikasi terhadap tanah kurang lebih 35 juta hektar pada tanah yang dianggap tidak subur lagi dan tanah terlantar.

\section{Agraria di Kota-Desa}

Kelemahan dalam manajemen tanah di perkotaan tampak dari meningkatnya harga tanah yang mendorong timbulnya spekulasi, kelangkaan pengembangan tanah perkotaan untuk pemukiman dan menjamurnya pemukiman liar. Pada umumnya tanah perkotaan itu diperoleh dari proses alih fungsi tanah pertanian, baik oleh Pemerintah atau swasta. Akses tanah di perkotaan bagi masyarakat menengah ke bawah sangat sulit, namun di sisi lain ada pihak perorangan atau badan hukum yang menguasai tanah perkotaan secara berlebihan untuk investasi dan spekulasi. Walaupun sudah diisyaratkan dalam UU no. 56/1960 tentang penetapan luas tanah 
pertanian bahwa mengenai batas maksimum tanah perkotaan akan diatur dengan PP, namun PP yang dimaksud sampai saat ini belum bisa terwujud.

Untuk mengatasi masalah penyediaan tanah perkotaan dapat ditempuh jalan sebagai berikut; 1 . Konsolidasi tanah perkotaan yang bertujuan mengatur kembali sebidang tanah dalam bentuk yang serasi untuk dibangun perumahan yang dilengkapi fasilitas umum, 2. Pembentukan badan hukum yang bertugas menyediakan tanah, mematangkan kemudian menyalurkan untuk berbagai keperluan, termasuk pemukiman (lembaga bank tanah), 3. Perolehan tanah dengan cara penukaran dengan sebidang tanah yang setara nilainya dengan atau berupa keikutsertaan dalam saham perusahaan yang mengambil alih tanah tertentu. Pada kenyataannya, walaupun sudah diupayakan cara pendanaan berupa subsidi silang, harga tanah yang relatif tinggi mengakibatkan pembangunan rumah sederhana dibayangi dengan harga akhir yang tidak terjangkau oleh mereka yang berasal dari kelompok marginal yang membutuhkan perumahan tersebut. Untuk mendorong realiasasi pembangunan rumah sederhana diperlukan upaya pengendalian berupa batas waktu penyelesaian dengan sanksi tertentu terhadap kelalaian yang terjadi. Tanpa adanya batas waktu, pemukiman tersebut akan selalu tertunda. Pemikiran lebih lanjut adalah para penghuni harus memiliki penghasilan setiap bulan, sehingga ada keterkaitan dengan lapangan pekerjaan disamping adanya mekanisme perkreditan yang mendukung. Permasalahan agraria yang sangat kentara di pedesaan adalah penguasaan lahan yang tidak merata. Ada sebagian kecil masyarakat yang menguasai, sementara mayoritas masyarakat desa yang kesehariannya mengelola tanah justru tidak mendapatkan aset tanah tersebut. Artinya ada kesenjangan kepemilikan aset berupa tanah.

\section{Penyelesaian Konflik}

Sengketa pertanahan dalam bahasa konflik dikategorikan sebagai 
manifest conflict yang merupakan akumulasi dari latent dan emerging conflict. Menurut KPA, ruang lingkup sengketa tanah adalah;

1. Sengketa agraria karena penetapan fungsi tanah dan kandungan hasil hasil bumi serta beragam tanaman dan hasil diatasnya sebagai sumber-sumber yang akan dieksploitasi secara massif.

2. Sengketa agraria karena program swasembada beras yang menyebabkan penguasaan tanah pada satu orang dan banyak petani yang kehilangan lahannya.

3. Sengketa agraria di areal perkebunan, karena pengalihan HGU maupun untuk Perkebunan Inti Rakyat (PIR).

4. Sengketa diatas lahan sebagai akibat penggusauranpenggusauran dan pengambilalihan tanah- tanah rakyat untuk pembangunan industri wisata, kawasan industri.

5. Sengketa karena penggusuran lahan dan pengalihannya tanah rakyat untuk pembangunan sarana- sarana yang dinyatakan sebagai sarana untuk kepentingan umum.

6. Sengketa karena pencabutan tanah rakyat untuk pembangunan taman nasional atau hutan lindung yang mengatasnamakan kelestarian lingkungan.

7. Sengketa akibat penutupan akses masyarakat untuk memanfaatkan sumber-sumber agraria non tanah (perairan, udara dan isi perut bumi) dan menggantikannya dengan hak-hak pemanfaatan terbatas untuk sekelompok orang atau perusahaan (Dianto B, 1998).

Secara garis besar tipologi sengketa pertanahan dipilah menjadi;

1. Kasus-kasus berkenaan dengan penggarapan atau pendudukan rakyat atas areal perkebunan, kehutanan, tanah-tanah yang dikuasai BUMN, ABRI.

2. Kasus-kasus yang berkenaan dengan pelanggaran peraturan landreform.

3. Kasus-kasus yang berkenaan dengan penyediaan tanah untuk pembangunan.

4. Sengketa perdata yang berkaitan dengan tanah. 
5. Sengketa berkaitan dengan tanah ulayat.

\section{Akar permasalahan agraria;}

1. Konflik kepentingan

2. Konflik struktural

3. Konflik nilai

4. Konflik hubungan

5. Konflik data (Maria S., 2004)

Pada masa orde lama, lembaga peradilan yang khusus, yaitu pengadilan landreform, melalui UU no.21/1964. lembaga ini disusun untuk menjawab persoalan akibat program land reform yang menjadikan masalah berkaitan dengan obyek landreform. Orde Baru, mengeluarkan UU no.7/1970 tentang penghapusan pengadilan landreform, sehingga pengadilan agraria dikembalikan kepada pengadilan umum.

\section{Land Reform}

Sekitar tahun 1980-an mulai terjadi krisis kepercayaan terhadap pembangunan yang dinilai gagal memberikan kesejahteraan bagi masyarakat. Krisis ini terjadi karena adanya kesenjangan yang mencolok antara negara utara dibandingkan dengan selatan. Salah satu kegagalan negara selatan melaksanakan proyek pembangunan adalah karena tidak melakukan pembaruan agraria. Struktur agraria pada negara selatan, yang mayoritas bekas wilayah kolonialisme tidak tertata dengan adil dan banyak yang timpang. Dalam sejarah agraria, kelas yang dominan selalu berusaha memiliki sumber-sumber ekonomi sebanyak-banyaknya dan menindas kelas dibawahnya. Pada masa feodalisme, monopoli lahan pada kelas penguasa dan bangsawan, sementara petani yang sehari-harinya mengolah tanah semakin kehilangan akses terhadap lahan itu sendiri. Transformasi masyarakat dari feodalisme ke kapitalisme modern secara perlahan diikuti dengan perombakan struktur agraria, sangat disayangkan ini hanya terjadi pada negara utara dan tidak di negara selatan (Benni, 2001). 
Isu utama pembaruan agraria adalah penguasaan tanah (land tenure) dalam bentuk pertuanan tanah (landlordisme) dan penyakapan bagi hasil. Penyakapan bagi hasil ini sangat perlu karena selama ini, hasil lebih pertanian diambil oleh kelas penguasa, tuan tanah dan petani besar sedangkan petani kecil dan buruh tani hanya mendapat bagian yang kecil. Bagi hasil dalam masyarakat kita adalah 50:50, bahkan ada yang 40:60, yang 60 untuk pemilik lahan. Agrarian reform dalam pengertian terbatas adalah redistribusi lahan, dalam arti luas adalah pembaruan dalam struktur penguasaan, struktur produksi dan struktur pelayanan yang mendukung.

Adapun tanah-tanah yang dibagikan tersebut berasal dari;

1. Tanah kelebihan batas maksimum

2. Tanah absentee

3. Tanah bekas swapraja

4. Tanah negara lainnya

Dalam UUPA ini, land reform di Indoensia dituangkan dalam program yang meliputi; 1. Pembaruan hukum agraria, 2. Penghapusan hak-hak asing dan konsensi-konsensi kolonial atas tanah, 3. Penghentian penghisapan feodal secara berangsurangsur, 4. Perombakan atas kepemilikan dan penguasaan tanah, 5. Perencanaan persediaan, peruntukan dan penggunaan bumi, air dan kekayaan alam yang terkandung didalamnya itu secara berencana sesuai dengan daya kesanggupan dan kemampuannya.

Pelaksanaan program land reform mencakup hal-hal sebagai berikut;

1. Larangan untuk menguasai tanah pertanian yang melampuai batas.

2. Larangan pemilikan tanah secara absentee

3. Redistribusi tanah-tanah yang selebihnya dari batas maksimum, tanah-tanah yang terkena ketentuan absentee, tanah-tanah swapraja dan tanah-tanah negara lainnya

4. Pengaturan soal pengembalian dan penebusan tanah-tanah pertanian yang digadaikan 
5. Pengaturan kembali perjanjian bagi hasil tanah pertanian

6. Penetapan batas minimum pemilikan tanah pertanian disertai larangan untuk melakukan perbuatan-perbuatan yang mengakibatkan pemecahan pemilikan tanah-tanah pertanian menjadi bagian-bagian yang terlampau kecil.

Agrarian reform diperlukan dalam kerangka pembangunan nasional meliputi;

1. Menciptakan pasar dan daya beli, tanpa adanya pemerataan tanah itu tidak akan ada daya beli, artinya juga tidak ada kekuatan pasar

2. Petani tanpa aset tanah sehingga petani tetap miskin dan tidak mempunyai tabungan

3. Meningkatkan ekonomi petani, pajak pertanain tetap minim

4. Tidak adanya land reform, maka tidak terjadi differensiasi yang luas terhadap pembagian kerja di pedesaan

5. Tanpa land reform tidak ada investasi pertanian oleh petani sendiri

6. Tanah menjadi obyek spekulasi, karena tidak mampu diproduksi secara produktif oleh petaninya sendiri, melainkan lebih pro kepada masyarakat perkotaan untuk kepentingan investasi (Benni setiawan, 2001). 


\section{Daftar Pustaka}

-Ali, Zainudin. 2005. Sosiologi Hukum. Jakarta. Sinar Grafika

Al Munawar, Said Aqil Husin. 2004. Hukum Islam dan Pluralitas

Sosial. Jakarta. Penamadani

Budiardjo, Miriam. 1993. Dasar-Dasar Ilmu Politik. Jakarta.

Gramedia

Chairuddin.1991. Sosiologi Hukum. Jakarta. Sinar Grafika

Constanzo, Mark. 2006. Aplikasi Psikologi dalam Sistem Hukum. Pustaka Pelajar

Faqih, Mansur. 1999. Analisis Gender dan Transformasi. Yogyakarta.

Pustaka Pelajar

Faqih, Mansur. 1996. Membincang Feminisme. Surabaya. Risalah Gusti

Fuady, Munir. 2007. Sosiologi Hukum Kontemporer. Bandung.

Citra Aditya Bakti

Ilyas, Yunahar. 2004. Korupsi dalam Perspektif Agama-agama. Yogyakarta. Kutub

Johnson, Doyle Paul. 1996. Teori Sosiologi Klasik dan Modern. Jakarta. Gramedia

Kansil. 2009. Pengantar Hukum Indonesia. Jakarta. Sinar Grafika Kelsen, Hans. 2006. Teori Umum tentang Hukum dan Negara. Bandung. Nusa Media

Musdah. 2001. Keadilan dan Kesetaraan Gender. Jakarta. Tim Pemberdayaan Perempuan Bidang Agama Depag RI Muryanti. 2010. Panduan Bantuan Hukum Bagi Paralegal . Yogyakarta. LBH Yogyakarta 


\section{DAFTAR PUSTAKA}

Prasetyo, Teguh. 2009. Ilmu Hukum dan Filsafat Hukum.

Yogyakarta. Pustaka Pelajar

Raharjo, Satjipto. 2008. Membedah Hukum Progresif. Jakarta.

Kompas

Raharjo, Satjipto. 1999. Hukum dan Masyarakat. Bandung. Angkasa

Raharjo, Satjipto. 2009. Hukum Progresif. Yogyakarta. Genta

Raharjo, Satjipto. 2009. Hukum dan Perilaku. Jakarta. Kompas

Raharjo, Satjipto. 2009. Penegakan Hukum. Yogyakarta. Genta

Santoso, Topo dan Ava Achjani. 2011. Kriminologi. Jakarta. Rajawali Press

Syahar, Saidu. 1986. Asas-asas Hukum Islam : Himpunan Kuliah. Bandung. Alumni

Susanto Stephen, Schafer 1969. Theories In Criminology. New York. Random House

. 2011. Kriminologi. Yogyakarta. Genta

Soekanto, Soerjono. 1976. Beberapa Permasalahan Hukum dalamKrangka Pembangunan

Sumardjono, Maria. 2008. Tanah dalam Perspektif Hak Ekonomi,Sosial dan Budaya. Jakarta. Kompas Indonesia. Jakarta. Penerbit UI

Teba, Sudirman. 2003. Sosiologi Hukum Islam. Yogyakarta. UII Press Indonesia

Waluyo, Bambang. 2011. Viktimology; Perlindungan Korban dan Saksi. Jakarta. Sinar Grafika

Wignyosoebroto, Soetandyo. Positivisme. Pakar Hukum Universitas Airlangga

Waryono . 2004. Dinamika Studi Gender. Yogyakarta. UIN Sunan Kalijaga

Waryono. 2009. Gender dan Islam; Teks dan Konteks. Yogyakarta. PSW UIN Sunan Kalijaga

Mertokusumo, Sudikno.1999. Mengenal Hukum (Suatu Pengantar). Yogyakarta. Liberty 


\section{Produk Undang-Undang;}

UU No. 7/2004 tentang Pengelolaan Sumber Daya Air

UU No.23/2004 tentang Penghapusan Kekerasan dalam Rumah Tangga

UU No.41/1999 tentang Kehutanan

UU No.13/2003 tentang Ketenagakerjaan

UU No. 5/1960 tentang Pembaharuan agraria

UU No.31/1999 tentang Korupsi

UU No.10/2008 tentang Pemilihan Umum (Pemilu,DPR,DPD dan DPRD)

UU No. 22/2009 tentang Lalu Lintas dan Angkutan Jalan

UU No. 23/2002 tentang Perlindungan Anak 